\title{
Irrigation of World Agricultural Lands: Evolution through the Millennia
}

\author{
Andreas N. Angelakıs ${ }^{1}$ (D), Daniele Zaccaria ${ }^{2, *}$, Jens Krasilnikoff ${ }^{3}$, Miquel Salgot ${ }^{4}$, \\ Mohamed Bazza ${ }^{5}$, Paolo Roccaro ${ }^{6}$, Blanca Jimenez ${ }^{7}$, Arun Kumar ${ }^{8} \mathbb{D}$, Wang Yinghua ${ }^{9}$, \\ Alper Baba ${ }^{10}$, Jessica Anne Harrison ${ }^{11}$, Andrea Garduno-Jimenez ${ }^{12}$ and Elias Fereres ${ }^{13}$ \\ 1 HAO-Demeter, Agricultural Research Institution of Crete, 71300 Iraklion and Union of Hellenic Water \\ Supply and Sewerage Operators, 41222 Larissa, Greece; angelak@edeya.gr \\ 2 Department of Land, Air, and Water Resources, University of California, California, CA 95064, USA \\ 3 School of Culture and Society, Department of History and Classical Studies, Aarhus University, \\ 8000 Aarhus, Denmark; hisjk@cas.au.dk \\ 4 Soil Science Unit, Facultat de Farmàcia, Universitat de Barcelona, 08007 Barcelona, Spain; salgot@ub.edu \\ 5 Formerly at Land and Water Division, Food and Agriculture Organization of the United Nations-FAO, \\ 00153 Rome, Italy; m.bazza55@gmail.com \\ 6 Department of Civil and Environmental Engineering, University of Catania, 2 I-95131 Catania, Italy; \\ proccaro@dica.unict.it \\ 7 The Comisión Nacional del Agua in Mexico City, Del. Coyoacán, México 04340, Mexico; \\ blanca.jimenez@conagua.gob.mx \\ 8 Department of Civil Engineering, Indian Institute of Technology, Delhi 110016, India; arunku@civil.iitd.ac.in \\ 9 Department of Water Conservancy History, China Institute of Water Resources and Hydropower Research, \\ Beijing 100048, China; wangyh@iwhr.com \\ 10 Izmir Institute of Technology, Engineering Faculty, Department of Civil Engineering, \\ Urla/İzmir 35430, Turkey; alperbaba@iyte.edu.tr \\ 11 Independent Scholar, Baton Rouge, Louisiana, LA 70802, USA; jharri32@gmail.com \\ 12 Food Water Waste Research Group, The University of Nottingham, Nottingham NG7 2RD, UK; \\ Andrea.GardunoJimenez@nottingham.ac.uk \\ 13 IAS-CSIC and University of Cordoba, 14004 Córdoba, Spain; ag1fecae@uco.es \\ * Correspondence: dzaccaria@ucdavis.edu
}

Received: 28 March 2020; Accepted: 24 April 2020; Published: 1 May 2020

\begin{abstract}
Many agricultural production areas worldwide are characterized by high variability of water supply conditions, or simply lack of water, creating a dependence on irrigation since Neolithic times. The aim of this paper is to provide an overview of the evolution of irrigation of agricultural lands worldwide, based on bibliographical research focusing on ancient water management techniques and ingenious irrigation practices and their associated land management practices. In ancient Egypt, regular flooding by the Nile River meant that early agriculture probably consisted of planting seeds in soils that had been recently covered and fertilized with floodwater and silt deposits. On the other hand, in arid and semi-arid regions farmers made use of perennial springs and seasonal runoff under circumstances altogether different from the river civilizations of Mesopotamia, Egypt, India, and early dynasties in China. We review irrigation practices in all major irrigation regions through the centuries. Emphasis is given to the Bronze Age civilizations (Minoans, Egyptians, and Indus valley), pre-Columbian, civilizations from the historic times (e.g., Chinese, Hellenic, and Roman), late-Columbians (e.g., Aztecs and Incas) and Byzantines, as well as to Ottomans and Arabs. The implications and impacts of irrigation techniques on modern management of water resources, as well as on irrigated agriculture, are also considered and discussed. Finally, some current major agricultural water management challenges are outlined, concluding that ancient practices could be adapted to cope with present challenges in irrigated agriculture for increasing productivity and sustainability.
\end{abstract}


Keywords: irrigation practices; Aztecs; bronze age; Byzantine times; Chinese dynasties; Egyptians; Harappans; Hellenic civilizations; Incas; medieval times; Mayas; Mesopotamia; Minoans; modern times; Ottoman times; Romans

\section{Prolegomena}

Historians and archaeologists believe that the Fertile Crescent [1] is the cradle of agriculture, written language, and monotheist religions. The area comprising the territories formerly called Mesopotamia (the origin of Mesopotamia's name is from the Greek words meso and potamos, i.e., the land between (meso) the Euphrates and Tigris rivers (potamos) and their tributaries), Assyria and Phoenicia, together with Lower and Upper Egypt, witnessed the domestication of crops by mankind some 10,000 years ago. It could be hypothesized that the birth of irrigation also took place there, soon after the start of agriculture. Given the long periods without rainfall in the Fertile Crescent, one could imagine that the first farmers diverted water to the dry lands as soon as they saw an opportunity to do so. In arid and semi-arid climates, irrigation is needed to sustain agricultural production because of insufficient or unevenly distributed rainfall during the crop-growing season and therefore water storage facilities must be constructed to buffer water demand and supply during the irrigation periods [2].

The initial irrigation activity must have been the simple diversion of water onto nearby cropped lands, which may have been done with bare hands (the diversion of water from streams into cropped land with bare hands is still practiced today as witnessed by the authors in several traditional societies) or with primitive tools used at the time. The use of earthen ridges and digging canals to convey water to land located further away from the water source must have followed some time later. Flood spreading - also called spate irrigation — as is still practiced today in several traditional rural communities, is probably the closest practice to the origin of irrigation.

Throughout history, the rise and decline of the civilizations that thrived in the Fertile Crescent, was closely dependent on harnessing water for agricultural production, which provided economic prosperity, social stability, and military power. Drought episodes of long duration often caused the replacement of ruling dynasties by new ones. It was also in this part of the world that the negative impacts of irrigation first appeared. Salt accumulation in the soil, stemming from lack of, inadequate drainage, or usage of poor-quality waters led to soil salinization and declining agricultural production. Agricultural practices require hydraulic and reclamation works such as flood protection, land levelling, and drainage.

It is well known that the development of agriculture in the Bronze Age allowed the subsistence of larger populations. There is also evidence that during the first millennium BC (Before Christ) agricultural productivity in Europe reached for the first-time levels capable of sustaining highly stratified societies [3]. According to [4], the beginnings of agricultural developments that led to the creation of Classical civilizations should be traced to the early Chinese dynasties, ancient Egyptians, Minoan and Mycenaean states of the actual Greece and to Indus valley civilizations. Additionally, Mayans and other pre-Columbian civilizations paralleled similar developments in Central and South America. Angelakis et al. [5] indicate that Egyptians and other neighboring civilizations exchanged knowledge with Minoans, Myceneans, Archaic and Classical Greeks. Thereafter civilizations, mainly Romans, inherited prehistoric technologies and developed them further, mainly by scaling up and implementing them both in urban and rural areas.

The use of drainage and irrigation practices are probably nearly as old as farming, although the earliest recorded examples of drainage and irrigation systems date to the Classical Greek and Imperial Roman periods [6,7]. However, archaeological studies revealed that the oldest irrigated agriculture in the Near East Region along the Nile riverbanks appeared in Egypt some 5000 years BC [8,9].

This paper describes the historical evolution of irrigation and discusses major achievements in terms of practices and technologies through the millennia. The most important and well-known civilizations worldwide are considered. It also attempts to provide insights into ancient irrigation 
technologies and management, highlighting features related to sustainability and adaptation to the environment, and its role in converting "marginal" lands into regular fields suitable for cultivation. Finally, the paper compares different technological developments among civilizations. These technologies are the underpinning of modern achievements in water science and are one proof that "the past is the key for the future".

This study is organized as follows: (a) Section 1 is an introductory one; (b) Sections 2 and 3 refer to the irrigation in pre-historic and historical times; (c) Section 4 refers to early Chinese dynasties; (d) Section 5 refers to late pre-Columbian civilizations; (e) Section 6 refers to medieval times; (g) Section 7 refers to late Chinese dynasties; (f) Section 8 refers to modern times; (h) Section 9 discusses the main agricultural water management challenges and future trends; and (i) Section 10 includes the epilogue and the concluding remarks.

The conceptual diagram of Figure 1 depicts the structure of this review paper.

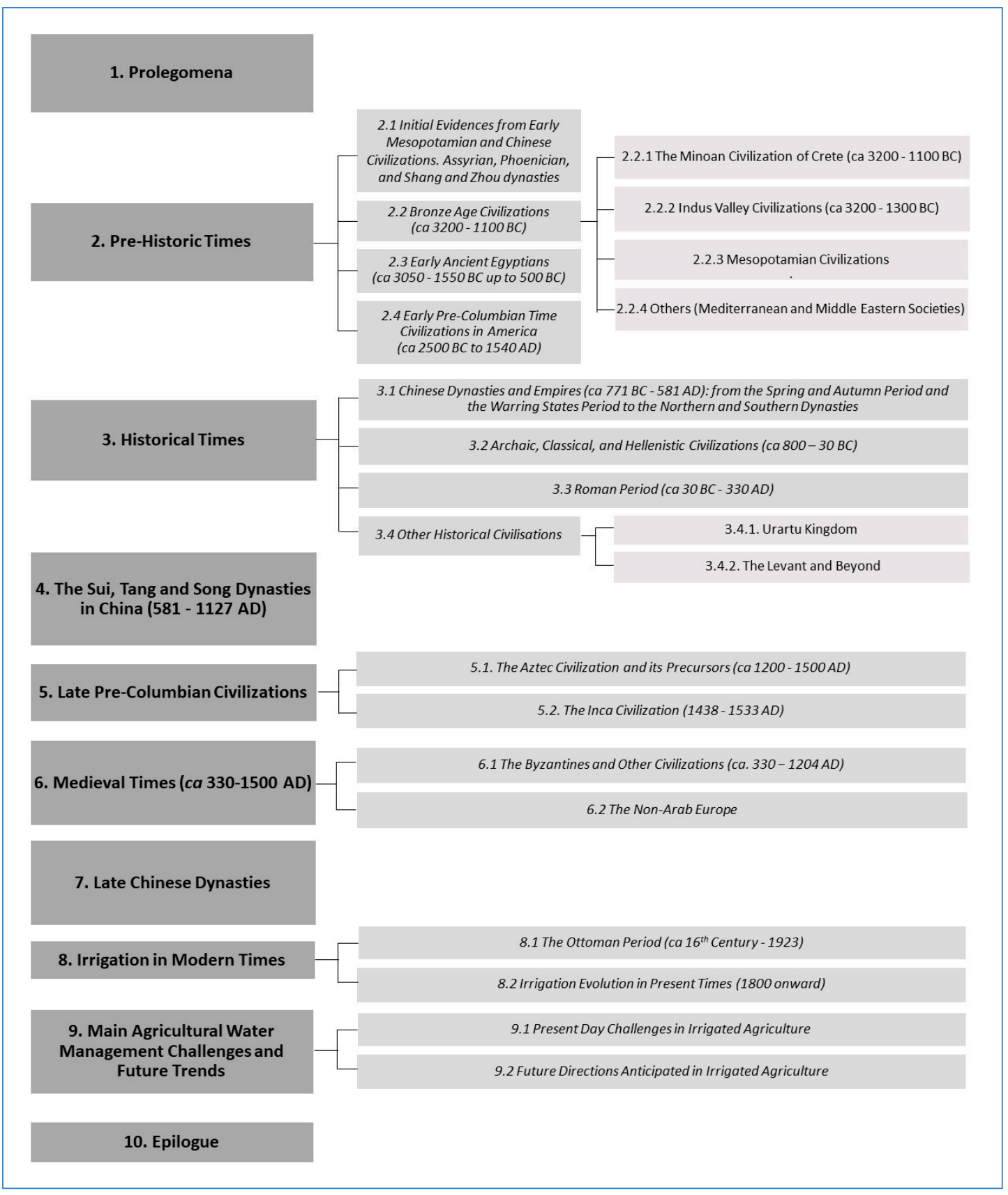

Figure 1. Structure of the present review paper. 


\section{Pre-Historic Times}

2.1. Initial Evidences from Early Mesopotamian and Chinese Civilizations. Assyrian, Phoenician, and Shang and Zhou Dynasties

The very early phases of irrigation development are difficult to document today. As indicated above, the initial irrigation practices at that time probably consisted of a simple diversion of water onto fields adjacent to watercourses. Physical remnants of such practices are not likely to last for more than decades after ceasing operation. The existing archaeological evidence of irrigation relates only to that irrigation infrastructure built for decades to a century of use. For instance, there is evidence that the oldest irrigated agriculture in the Fertile Crescent was practiced in Egypt some 5000 years $\mathrm{BC}$ and consisted of large flat basins built for diverting floods to grow winter crops along the Nile riverbanks [10]. At the peak of floods, water was naturally diverted into these basins where it remained for 40 to 60 days [9]. The system was later refined and gave rise to basin irrigation. More advanced systems comprising earthen banks, basins of various sizes, regulated sluices to direct floodwater, and other structures have been reported in the area [11].

Techniques similar to those used in Egypt, with adaptations to the Tigris and Euphrates rivers, were used in Mesopotamia ca 3000-5000 years BC [12]. In Mesopotamia, a canal connected to and crossing through the ancient Semitic city of Mari was used for irrigation [13,14].

Early farming and stock breeding communities appeared in China in the mid Neolithic period about 7000 years ago. Primitive paddy fields emerged in the mid and lower reaches of the Yangtze River, where abundant water resources and flat terrains could be found. Humans began to plant rice in the lowland areas near rivers and lakes, which resulted in the emergence of the primitive irrigation and drainage engineering practices in the present Hemudu, Yuyao County, Chekiang Province [15]. In the mid-late Neolithic period, humans began to settle in areas far away from the rivers, which led to the excavation of wells for irrigation.

According to archaeological discoveries, the earliest water wells in China were excavated about 6000 years ago also in Hemudu [16]. However, in this period wells for irrigation were mostly confined to courtyards and gardens.

Later, the Xia, Shang, and Zhou dynasties (ca 2100-771 BC) developed in the lower reaches of the Yellow River. The Shang dynasty - the first Chinese dynasty to leave historical records-is thought to have ruled from about 1600 to 1046 BC. However, one must distinguish Shang as an archaeological term from Shang as a dynastic one [10]. In this region, summer and autumn are typically heavy rainy seasons, so it became necessary to dig canals to drain off excess water from farmlands and reduce flooding. According to legends, excavation of farmland canals began taming water in the times of Yu the Great ( ca 2123-2025 BC). Based on archaeological research, the symbols for farmland and canal ('田 ('“') appeared in the oracle of the Shang dynasty, and referred to a canal near a plot of farmland [17]. Farmland canals became an integral part of a well system in the Western Zhou dynasty (ca 1045-771 $\mathrm{BC})$, leading to the well-field irrigation canals system of Jing Tian Gou Xue. Under this system, a piece of land was divided into nine '井'-shaped plots with a storage well in the middle, while the other eight plots were devoted to agricultural fields and surrounded by irrigation canals. When the dry spring and winter periods came, farmers diverted water from the canals and/or wells to the fields. Farmers who lived near the city of Haojing, the capital of the Western Zhou dynasty, diverted water from Biaochi, a storage pond connected to the rice paddocks with irrigation canals. In this period, the number and size of irrigation areas were very small.

\subsection{Bronze Age Civilizations (ca 3200-1100 BC)}

\subsubsection{The Minoan Civilization of Crete}

One example of an early civilization that focused on irrigation is the Minoan. The Minoans selected their first settlements based on defense, food and water conditions. During the Minoan era 
(ca 3200-1100 BC) the development of agriculture in Crete and other islands in South-Eastern Greece was necessary to support a rapidly growing population. Agriculture played an important role in the development of water management. Cereals, wine and olive oil were the three main agricultural products in Crete and throughout the Mediterranean prehistory. Sophisticated techniques were applied to increase the amount of food produced and secure its quality with the introduction of new plant species and terraced agriculture [18]. Although not documented in the archaeological records, irrigated agricultural lands should have developed in prehistoric Crete, especially in cereal and grapes growing areas [19] not only to increase but also to stabilize production.

In the Neopalatial period ( $c a 1750-1450 \mathrm{BC}$ ), the practice of irrigation and drainage of agricultural lands became very important. The most famous irrigation systems of that time are called linies (linea $=$ straight line), identified in the Lasithi Plateau in eastern Crete that were irrigated during the Minoan era [20]. This conclusion follows from findings in the Neolithic and Minoan settlements in Kastellos, Plati, and the Kronion's sacred caves in Trapeza and at Idaion Andro in the Lasithi Plateau. Numerous drainage and irrigation channels intersected groves, creating a very attractive view. These techniques are thought to have been transferred later by Minyans, another prehistoric people of Greece like Minoans, to Orchomenos in central Greece [20]. In fact, traces of these techniques were observed during the reclamation project of Lake Kopais in 1886 [2].

In Minoan Crete, environmental and socio-economic conditions forced the development of pioneering actions for implementing water technology in agriculture and water management in general. Such creative and innovative technologies can be traced in different areas of the world, at different times and for several activities, like in the terraced agriculture in pre-Columbian Peru [19].

In the Minoan palaces and settlements, management of water resources varied according to local conditions, which were determined mainly by climate, rainfall, groundwater availability and soils [5]. In settlements of the eastern Crete (e.g., Zakros, Palaikastro, and Komos) water needs were mainly met with groundwater. So far, several wells have been discovered in Palaikastro with depths ranging from 10 to $15 \mathrm{~m}$ [21]. There are also indications that the Minoans invented the shaduf or shadoof-the simple hand operated water-lifting device still used in India, Egypt, and some other countries-during the Meso-Minoan period ( $c a$ 2150-1600 BC) in the eastern part of the island. Similar devices were in use in Mesopotamia as early as at the time of King Sargon of Akkad of the Sumerian city-states in the ca 23rd and 22nd centuries BC [22].

In the valley of Choiromandres, located on the southeastern edge of the Zakros area at the eastern end of Crete, Greece, an integrated management system covering an area of around $7.5 \mathrm{hm}^{2}$ has been discovered [23]. The valley consists of a rocky ravine with high slope from east to west. During the second millennium BC, the residents attempted to regulate the flow of streams through a system of two dams in series. In addition to using water for irrigation, the dams were built for the protection of arable land from soil erosion caused by the storm water runoff flowing into the river after heavy rainfall. The first attempt was made during the Propalatial period ( $c a 1900-1750$ BC), with the dams built using megaliths during the Neopalatial period ( $c a$ 1750-1450 BC). The largest of them has a length of $27 \mathrm{~m}$ (at the top) and a height today of $3.10 \mathrm{~m}$, while the thickness of the base is greater than that of the crest. In the east side, a channel at the rock surface existed that probably served as a spillway. The upper part of the dam was rebuilt in the late Classical and Hellenistic periods. Hydro-technologies including irrigation systems developed by Minoans and Mycenaeans were transferred to neighboring civilizations such as Egyptians, Etruscans, and Dorians and later transferred by them to Archaic and Classical Greece, with which they had "built bridges" [5].

Along the watercourse downstream of the dam, retaining walls were built to support other walls parallel or perpendicular to the riverbed in order to achieve containment and proper flow channeling (Figure 2). At the lower end of the ravine, a permeable barrier was constructed, enabling control of irrigation water in the downstream terraces. 


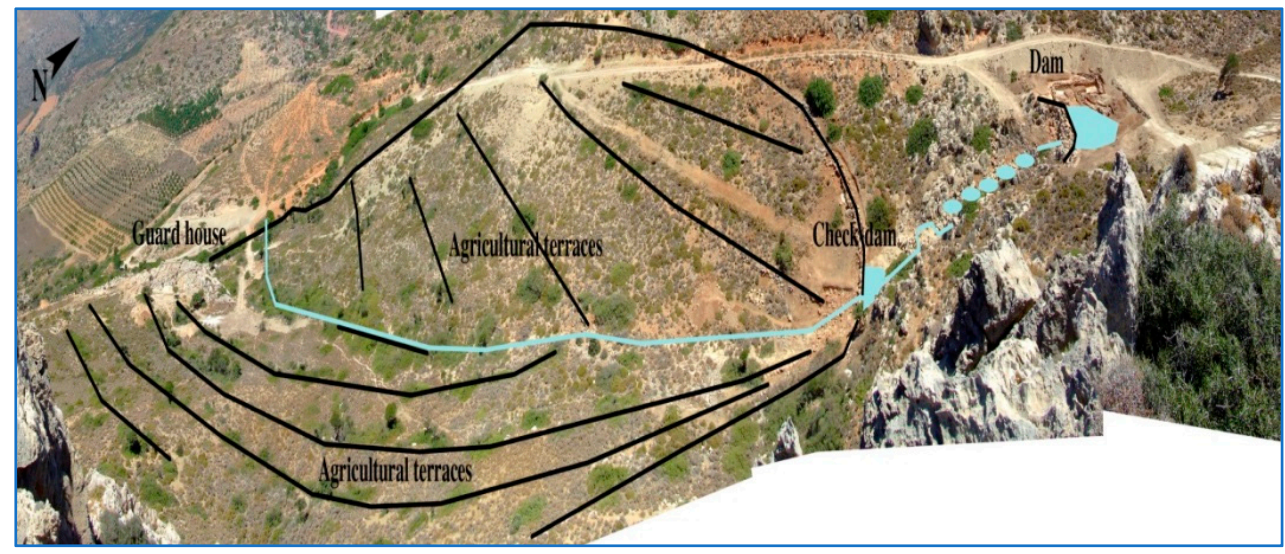

Figure 2. The main dam, the check dam, and the irrigated agricultural terraces in Choiromandres (modified from [23]).

Irrigation projects at Choiromandres remained in use until the end of the Classical period or the beginning of the Hellenistic period. This water management system can be considered as an example of public works originally constructed in the Bronze Age. This case could inspire to investigate other archaeological sites in Crete, contributing to a better understanding of the Bronze Age practices related to the management of water resources [24]. Other irrigation projects of that period are known from Pitsidia and Pseira, which are in Southeastern Crete [25].

General movement of populations from higher elevations and marginal zones with little arable land to landscapes of low alluvial terraces occurred during the late Protopalatial and the early Neopalatial period [26]. These areas provided better access to water supplies, whether groundwater or lower reaches of riverbeds, and they were better suited to the intensive cultivation of cereals, legumes, olives and grapes, as long as they were efficiently irrigated. Such developments are recorded at Malia and Pseira, where Neopalatial dams allowed more intensive exploitation of the limited agricultural potential of the island in response to increasing population [27].

Some other water management systems have been discovered in Crete. The outputs of the central sewerage and drainage systems in palaces and cities at Knossos, Phaistos, Zakros, and Malia appear to be similar. However, the palaces of Knossos and Zakros disposed rainwater and wastewater into the torrent Kairatos and the sea, whereas the palace of Phaistos had collection facilities and diversion of raw runoff into farmland. Angelakis and Spiridakis [28] described how similar techniques of sewerage and storm water runoff management were used in other cities and palaces of Minoan Crete.

\subsubsection{Indus Valley Civilizations (ca 3200-1300 BC)}

The Indus culture, one of the world's great civilizations, was based on two river systems, the Indus and the Ghaggar-Hakra [29]. To feed the inhabitants of its cities, this civilization relied on farmers of the Indus valley who produced peas, sesame seed and cotton, among other main crops. These farmers cultivated large fields using wooden ploughs pulled by oxen, as witnessed by model ploughs - possibly toys-that archaeologists have found in the area. They also domesticated wild animals for harvesting crops at their farms, and utilized their power for cultivation [30].

Irrigation systems of ancient India were infused from those developed earlier in Egypt and Mesopotamia. Violett [31] describes these early Indus valley cultures as the great hydraulic civilization of Harappa, which developed around the 3rd and 2nd millennium BC.

Farmers relied on water from the Indus and the Ghaggar-Hakra rivers for agriculture purposes, where multi-cropping systems were practiced. Channels connected to these rivers conveyed water to agriculture fields, which used "flooding-based irrigation" [29,32]. Seeds were sown after floods, which made the soil rich in nutrients and allowed growing different crops in winter and summer. During cooler wet winter periods, "Rabi" crops were grown and harvested in spring, whereas "Kharif" 
crops were cultivated and harvested in India, Pakistan, and Bangladesh during the subcontinent's monsoon season.

According to Wright et al. [29], the source of water used for irrigation and the method of its application for irrigating crops differed among the sites located in different agro-ecological zones. These differences can be seen in three subdivisions of the Harappan civilization, that is, sites such as Harappa, Mohenjo-Daro, and Lothal. In a Harappa site, on the Ravi River, people used summer flooding, summer oxbow lakes and summer and winter monsoons for agriculture, whereas in Mohenjo-Daro, located on the Indus River, farmers relied on summer sheet flooding, winter rains and hillside dikes. In a Lothal site, located on the Bhagavo River, monsoon season rains supported agriculture.

The Indus Valley Civilization (ca 2600 BC), in present-day Pakistan, also had early canal irrigation systems. Large-scale agriculture was practiced in the area and an extensive network of canals was used for irrigation. Sophisticated irrigation and storage systems of surface tanks and underground reservoirs were developed [33], like at Girnar ca 3000 BC [34]. These farmers were probably among the earliest to take water from underground wells, in addition to surface river water. The shaduf, known as denkli or paecottah in India, was used in the Indus valley at the time for pumping water and irrigating agricultural land. Besides, some of the pictures on toys from the Indus Valley civilization indicate that there was a proper system of water supply to different houses and places with underground pipelines or aqueducts (Figure 3). Women were responsible for the water supply to the different places in town.

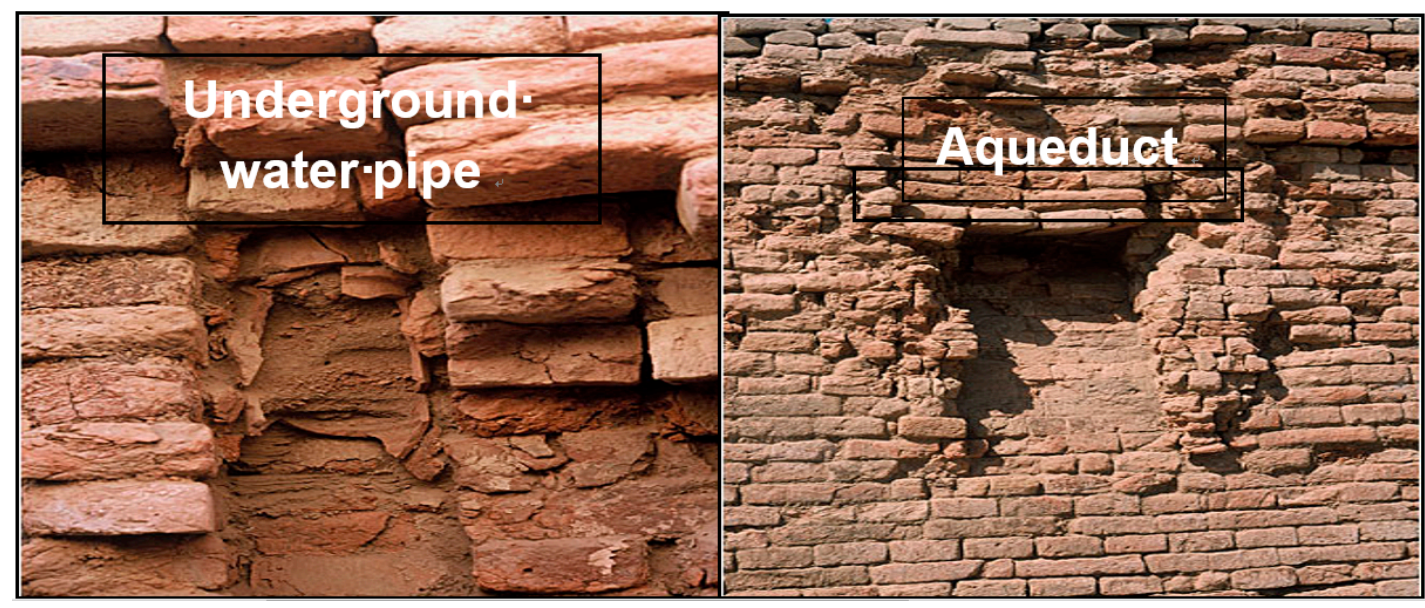

Figure 3. Underground pipe/aqueduct at Mohenjo Daro, Pakistan (modified from [32]).

\subsubsection{Mesopotamian Civilizations}

The city-state of Babylon, located along the Euphrates River, was founded ca. 2300 B.C. by the ancient Akkadian-speaking people of southern Mesopotamia, which became a major military power under Amorite King Hammurabi, who ruled from ca 1792 to 1750 BC. The regulation of water usage followed the initial irrigation developments in that region. The first known written rules related to irrigation date back to the era of that Babylonian King who wrote a code of law based on previous Sumerian rules. Additionally, the Hammurabi law code introduced three key concepts that created the foundation for collective irrigation management [35]. The key concepts were: (a) proportional distribution, whereby a grower receives water in proportion to the amount of farmed land; (b) definition of an individual farmer's responsibility towards the community, by safeguarding the canal sections on his property, accepting community-shared rules such as water rotations and liability for damages caused to neighbors owing to negligence or malice; and, (c) water apportionment and policy of irrigation arrangements being the collective responsibility of beneficiary farmers [36,37]. These concepts constituted the foundations of irrigation development in the region, and although they were abandoned for long periods in different areas, today they still represent excellent key principles for collective irrigation management. The goals were to ensure farmers' participation in 
the construction and management of infrastructures and achieve an equitable distribution of water to avoid conflicts. It is disputed among legal historians whether early Greek law was inspired by these early Mesopotamian examples [35].

The scale of irrigation in the Indus Valley was also larger than that in Egypt and Mesopotamia, but also more active due to the different characteristics of the rivers involved. Eridu is believed to be the first place that grew into a city as the result of irrigated agriculture development [9]. The region flourished later, during the period of the Babylonian dynasty, especially under the rule of Hammourabi. The well-known Hanging Gardens of Babylon-one of the Seven Wonders of the World-are believed to have been built during the Neo-Babylonian dynasty, under the king Nebuchadnezzar (ca 604-562 BC).

\subsubsection{Others (Mediterranean and Middle Eastern Societies)}

Other Mediterranean and Middle Eastern societies of the region also developed elaborate techniques for small-scale water collection, storage and conservation in the highlands. Rock-walled bench terraces and rainfall water diversion have been used in the present Lebanon nearly 3000 years ago. Similarly, Yemen is well known for its ancient terraces that facilitated the successful cultivation of crops on steep terrains. Archaeological evidence in the Negev have shown that arid-zone farming/irrigation techniques of the type known for North Africa (e.g., wadi valleys terracing) started developing as a viable alternative to exploiting the arid environment since the Bronze Age [38]. Examples of traditional rainwater harvesting, and soil and water conservation works known as "Jessours" have been developed in the southern part of Tunisia (Figure 4). They consist of systems with earthen dikes collecting runoff and spillways in areas where annual rainfall is less than $250 \mathrm{~mm}$.
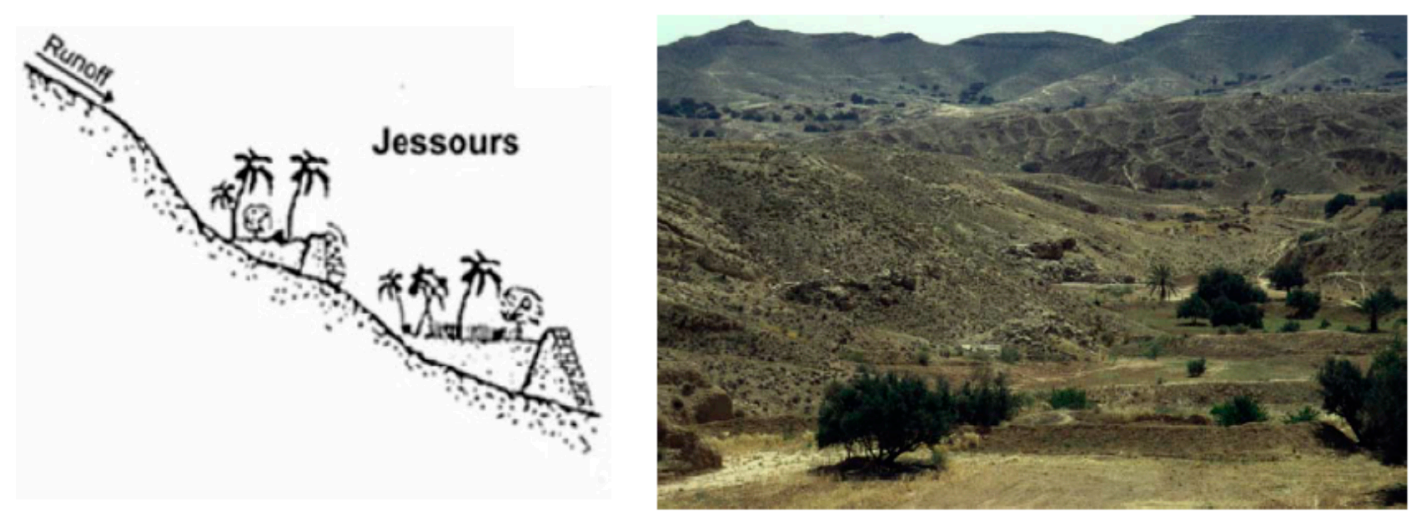

Figure 4. Jessours in southern Tunisia for growing tree crops (adapted from [39]; photo of A. Bahri).

Farmers used to build earthen dams (known as tabias) across the valley floors to trap run-off water and silt. Small terraces collecting this water were created for growing crops and fruit trees that would not survive otherwise in such arid climate. They were based on hydro-solidarity: farmers would help each other rebuild the spillways when they were destroyed by heavy rains and flash floods. Studies have been conducted at the INRGREF [39] on these early examples of water regulation and management works.

Another clever system of water collection and conservation in agriculture, believed to have originated in North Africa in the past, is "pot-watering" or "jar irrigation". It consists of burying a water-filled clay jar near a tree seedling to allow slow moisture diffusion to the plant roots. Such system is still used today to grow trees for halting the progression of sand dunes in southern Morocco. The jar helps capture and maintain moisture in the upper soil layers. All these desert agricultural systems represent general evidence of a well-established level of development by 1000 BC, which reached a rather high degree of sophistication in development by the so-called "Israelite III Period" ( $c$ a 850-600 BC) [38]. The use of soil-embedded porous jars is one of the oldest localized, high-frequency (or continuous) irrigation methods. Although the exact origin and antiquity of the method cannot be 
established with certainty, numerous reports have attested to its use by traditional farmers throughout North Africa and the Near East [40].

\subsection{Early Ancient Egyptians (ca 3050-1550 BC up to 500 BC)}

The ancient Egyptians developed irrigation systems to use water of the Nile River for a variety of purposes. Notably, the irrigation granted greater control over the agricultural practices [41]. Despite the fact that irrigation was crucial to their agricultural success, there were no statewide regulations on water control; rather, local farmers were responsible for irrigation. They practiced basin irrigation when water levels of the Nile were sufficiently high during flooding. The earliest and most famous reference to irrigation in Egypt was found on the mace head of the Scorpion King, which was dated to about 3100 BC [42].

The first major irrigation project in Egypt was built about 3050 BC by the First Egyptian dynasty. From around $2100 \mathrm{BC}$, several ingenious systems for irrigation were in use, including a $20 \mathrm{~km}$ long canal to divert Nile floodwaters to a lake. The Sadd el-Kafara was a masonry embankment dam, one of the oldest dams in the region that was built during the Third or Fourth dynasty, i.e., between $c a 2686$ and 2498 BC $[43,44]$, but was eroded by floods before being used. Across the Red Sea, the oldest dam on the Arabian Peninsula, Marib Dam in today's Yemen, was built ca 500-600 BC.

The Egyptian "shaduf" (Figure 5) and the water wheel, or "noria" or "sania" are probably among the earliest devices for lifting water from the Nile River for irrigation and domestic uses [12]. A modified version of the shaduf, called locally Diou or Dlou, was developed in North Africa and the Arabian Peninsula at the beginning of the $c a 12$ th century BC [45]. It was refined later on with the introduction of a pulley and animal traction for lifting water from deep wells.

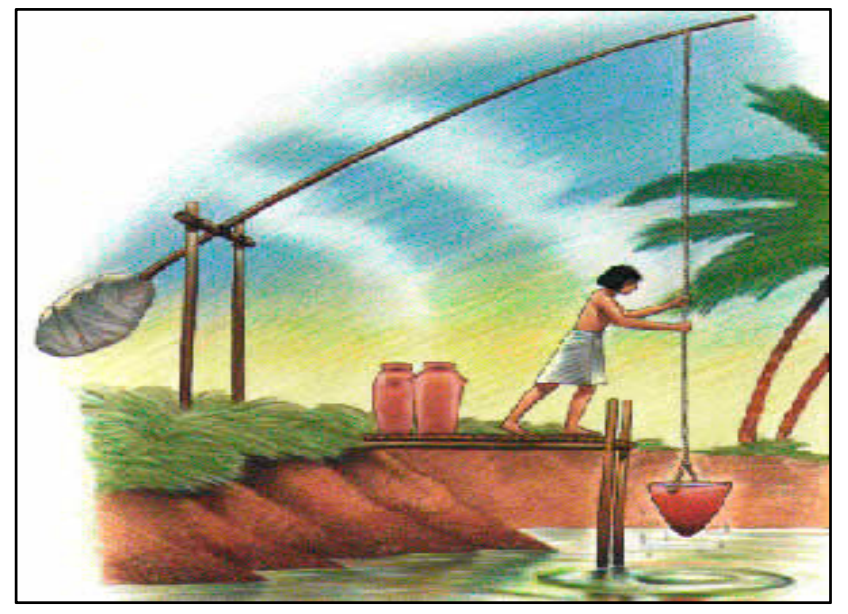

Figure 5. Egyptian Shaduf (adapted from [12]).

The noria or Egyptian Wheel, thought to be the first vertical water wheel, was invented in Egypt around the $c a$ 4th century BC [46]. However, its diffusion is typically associated with the Arab civilization, being the animal-powered noria considered as the higher symbol of the Islamic imprint upon irrigation technology. The hydraulic wheel was first built in Fez, Morocco, in the 13th century [47], then spread to other parts of North Africa.

A different version of the noria is the Persian Wheel (Figure 6), whose date of invention is not well known. It consists of an endless series of pots of unequal weight turned over two pulleys [48], and it is therefore classified as a pump rather than a water wheel. This device, in its different versions, represents the ancestor of water pumps and modern hydropower systems. The system used for lifting water to irrigate the Hanging Gardens of Babylon remains a mystery, although Greek historians describe it as consisting of something similar to an Archimedes' screw or chain pumps, each consisting of two large wheels powered by slaves. 


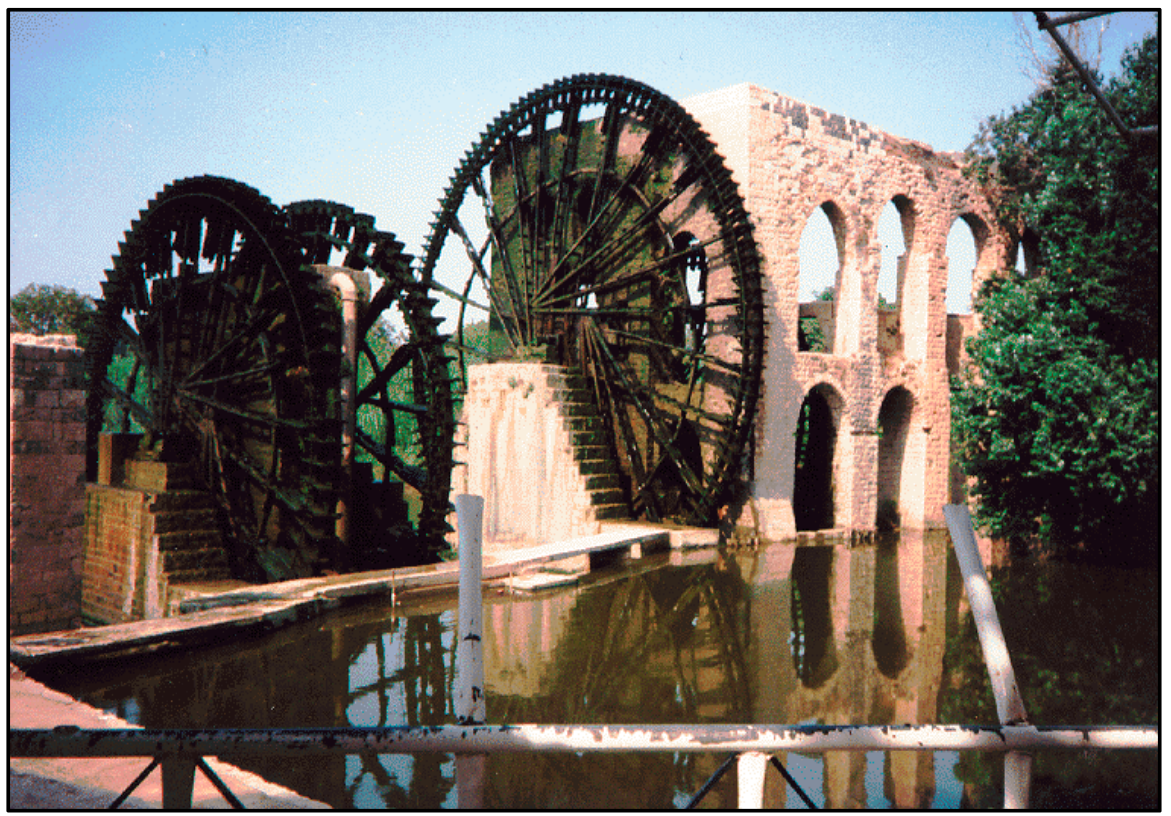

Figure 6. Noria in Hama, Syria [48].

The ancient Egyptians developed a system for monitoring the water flow in several places along the Nile River. The system (nilometer) consisted of marking the level of water and comparing it with those of previous years, thus allowing predictions with some accuracy of the following year's high marks. At least 20 "nilometers" were spaced along the river, and the maximum level of each year's flood was recorded in the palace and temple archives [49]. The early version of the system consisted of marked flights of stairs and has been used for thousands of years. The knowledge of Nile's flow level helped managing irrigation schemes.

\subsection{Early Pre-Columbian Time Civilizations in America (ca 2500 BC to 1540 AD)}

The Prehispanic Maya lived and farmed in a region with few permanent water bodies that were affected by distinct rainy and dry seasons (map presented in Figure 7). Maya farmers had to predict the start of the rainy season and the time for planting their crops, so that seedling could be sustained by the rains. Seasonal water bodies, such as 'aguadas' (rain-fed depressions), 'bajos' (wetlands), and swamps provided natural water resources that disappeared by the end of the dry season after supplying the needed water. As settlements grew, the Maya began to develop new ways of providing adequate water supplies. Unlike other civilizations, the Maya did not use real direct irrigation, but instead constructed rather elaborate water management systems to capture, store, and redistribute water for supporting both urban life and large-scale agriculture.

While most of Maya's water management systems were constructed to cope with water scarcity, in the wetlands of northern Belize the Maya built ditches and canals that recovered arable land from the karst seasonal wetlands, i.e., the bajos [50]. 


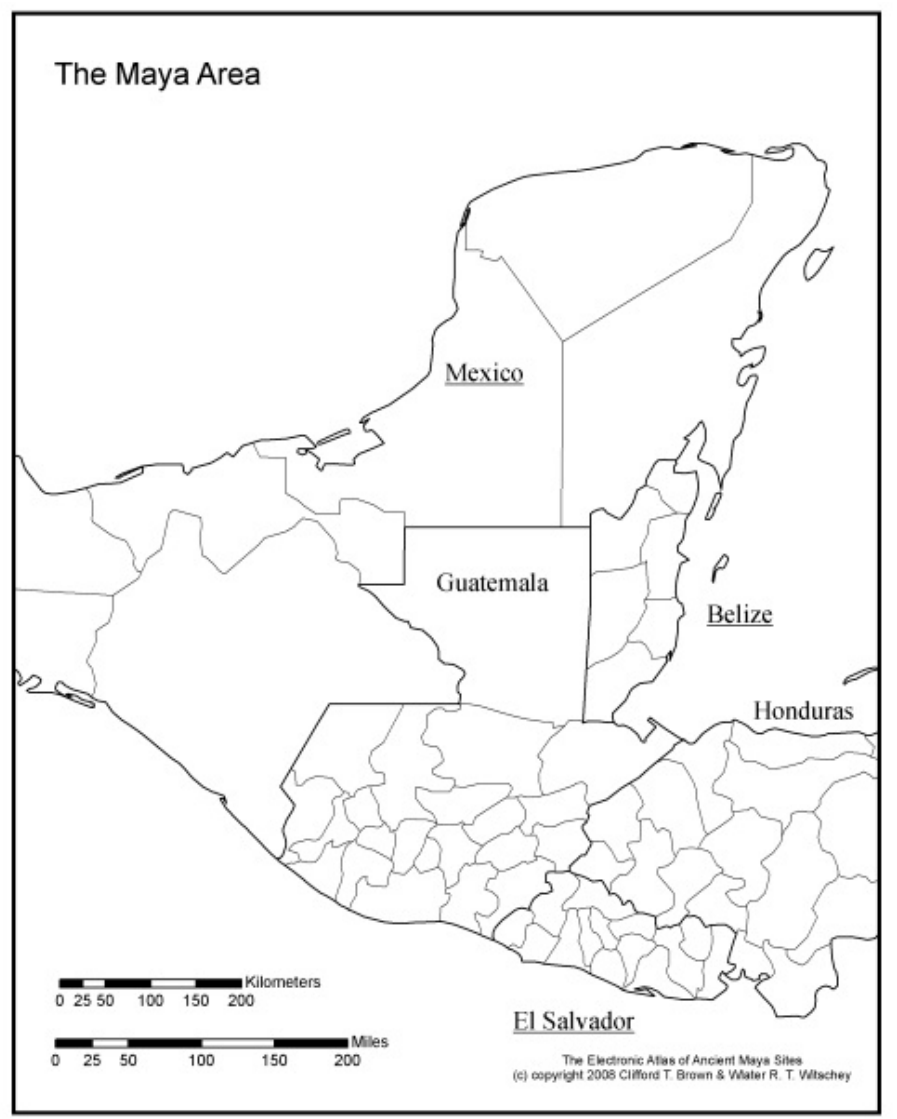

Figure 7. Map of the Maya area (modified from [51]).

Prehispanic Maya farmers practiced swidden agriculture (slash and burn). They cleared forest areas by burning prior to planting multi-crop fields, and then fertilized the system by letting the cinders remain in the field. Those areas were named "milpas" and were planted with both annual and perennial crops varying from corn to fruit trees. These sites were farmed for a few years, and then allowed to fallow to recover fertility and regrow forest vegetation before starting a new burning cycle. This agricultural system better maintained the fertility of the land, limited the susceptibility of crops to pest and diseases, and required little input from water management systems. Population expansion caused these systems to be unsustainable [52], as the fallow cycles were shortened beyond reasonable periods to maintain production. Nevertheless, milpa agriculture continues being practiced today by some traditional small farmers in Central America, with limited revenues. By the Late Preclassic period ( $c a 300 \mathrm{BC}-250 \mathrm{AD}$ ), Maya farmers modified the natural water bodies to create reservoirs and support growing communities. The largest Preclassic Maya centers, such as El Mirador, were built in the swampy Petén of North Guatemala, where naturally abundant water provided an ideal basis for constructing reservoirs capable of supporting cities [53]. Many of the great water management systems in the height of the Late Classic period ( $c a$ 600-900 AD) were built on the foundation of Preclassic reservoirs, modifying the natural 'aguadas' and 'bajos'. This is especially true at Tikal, where extensive study work has been done to understand the characteristics of the reservoirs system.

The natural water reservoirs were expanded, lined with plaster, and maintained with a system of plants and microbial flora that kept stored water potable throughout the dry season [54]. At its height, Tikal was home to as many as 100,000 inhabitants, whose needs for drinking and irrigation water were met by a system of ten reservoirs, at least four of which laid within the central precinct of the city. The reservoirs of Tikal stored runoff from rainfall that was flowing over the plastered ground, channeled into a series of reservoirs that fed first the elite residences, then those of lower-status families and finally ran towards agricultural fields in the outskirts of the city. Though the construction of 
Tikal's reservoirs (Figure 8) began in the Late Preclassic period, the construction program was greatly expanded in the Classic period to meet the needs of a rapidly growing urban population [52,55]. Later, despite Tikal being abandoned for nearly a millennium, the reservoirs continue storing and regulating water throughout the year.

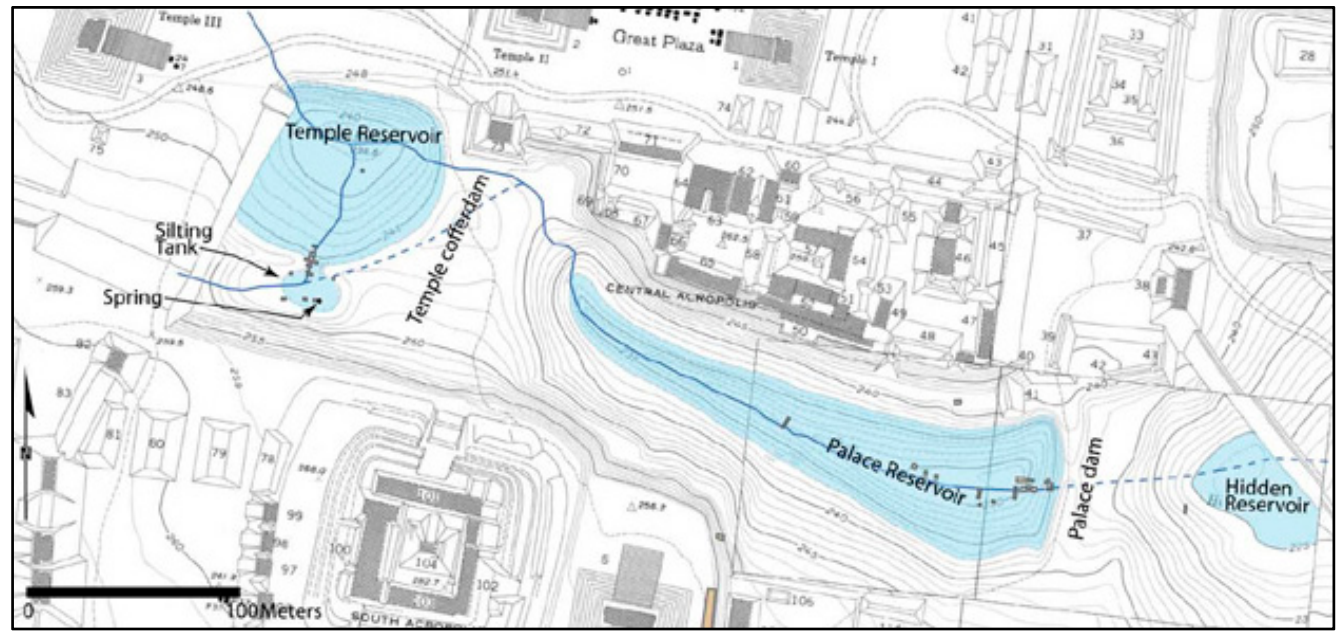

Figure 8. Map of Tikal's central reservoirs (adapted from [56]).

Unlike the Southern Lowlands, the Northern Lowlands of the Yucatán Peninsula have far fewer water bodies. In order to create reservoirs and store water, the northern Maya constructed 'chultunes', small storage tanks excavated into the bedrock. The chultunes were used by both hinterland farming households and larger centers, where the storage pits complemented the reservoir systems to supply larger urban populations with adequate water throughout the year [57].

In the wetlands of Northern Belize, the Maya faced a different problem, i.e., the overabundance of water. Maya farmers built a series of raised beds surrounded by canals, which enabled them to farm in swampy lands that provided fertile sediments and water for their crops, and aquatic animals to supplement their diet [58]. This system is reminiscent of the Aztec chinampas, though on a smaller scale.

Despite these elaborate water management systems, the Classic Maya, like all human societies, faced serious environmental challenges. A series of multiyear droughts, known from speleothems and sediment cores, hit Central America between ca 500 and 1000 AD, with the greatest occurring during the 9 th century AD [59]. The most severe droughts coincided with dramatic political changes, as Maya cities were abandoned and the elite fell from power. After the fall of major urban centers in what is often referred to as the Maya Collapse, the majority of water management systems were abandoned. Nevertheless, hinterland communities remained in place, and smaller reservoirs and other systems continued to be used by the Postclassic ( $c$ a 900-1521 AD) Maya. Spanish colonizers attempted to subvert indigenous practices and enforce European agricultural traditions; however, many traditional agricultural practices continued to today.

\section{Historical Times}

\subsection{Chinese Dynasties and Empires (ca 771 BC-581 AD): from the Spring and Autumn Period and the Warring States Period to the Northern and Southern Dynasties}

As a country built on the basis of agriculture, China has made a great deal of admirable achievements in agricultural related technologies, as indicated for the earlier periods of Chinese civilization. Irrigation, as a critical part of agriculture, witnessed some of the most important inventions during that time. Generally, all governing dynasties in Chinese history spent a great deal of manpower, material resources and money into various water conveyance projects. However, most of these projects 
were built in the major agricultural regions, and could not cover the high altitude areas or those located far away from water sources. Subsequently, the Chinese searched for water distribution equipment and devised the waterwheel to meet the need to extend irrigation throughout the entire country [60].

After the capital of the Zhou dynasty moved to Luoyang on Henan Province in 771 BC, China entered the Spring and Autumn Period ( $c a$ 770-476 BC) with the imperial power declining and the country torn apart by vassals. Along with the transformation of social system and the development of social productivity in this age, the ancient well-field system, described before, collapsed, thus the well-field irrigation canal system was abandoned. In the Spring and Autumn Period a new style of irrigation system suitable for the hilly areas was created, i.e., constructing several storage ponds at the sites of natural depressions, and connecting the ponds in series through excavated canals, storing surface run-off, and regulating water resources through these ponds for more efficient use of water. It was called melon-on-the-vine irrigation because its canals looked like vines and its storage ponds looked like melons on the vine. The earliest irrigation system of this type was in Quebei, located in Shou County, Anhui Province, and came into operation about 2500 years ago.

In the Warring States Period (ca 457-221 BC), while vassal states vied for supremacy, irrigation received universal attention in order to make their states rich and build military power, leading to the construction of large irrigation projects, which had additional functions. Three of these projects are famous: the first is the Zhengguo canal diverting water from the Jinghe river, built by the Qin dynasty and located in the middle of the Yellow River basin; the second is the Dujiang weir, located in the Minjiang River, tributary of the Yangtze River, also built by the state of Qin; the third consists of 12 canals diverting water from the Zhanghe River, tributary of the Haihe River, which was built by the Wei dynasty. The capital of Qin state, Xi'an, was located in the Yellow river basin as previously indicated. The construction of the Zhengguo canal made the state of Qin powerful and prosperous, ultimately leading to annexation of the Qin state by other vassal states. In addition, mostly depending on irrigation by the Zhengguo canal, the Yellow Rriver basin became the first economic center of China [61]. Afterwards, building of the Dujiang weir made the state of Qin smoothly unify the South of Five Ridges area, and made the Chengdu Plain known as the "land of abundance" because people there were able to control floods and droughts diminishing hunger in the region.

During the Qin and Han dynasties ( $c 221$ BC-220 AD), with the capital still located in Xi'an, development of irrigation in the Yellow River basin continued receiving high attention. Many irrigation projects, such as Baigong, Liufu, Bai and Longshou and other canals, were constructed during the Western Han dynasty. The Central Shaanxi Plain became the richest region in China, with its wealth representing $60 \%$ of the entire country. Meanwhile, the storage pond irrigation systems had greatly developed in the Central Shaanxi Plain of the Hanshui River basin, and in the Nanyang and Runan areas of the Huaihe River basin. Moreover, irrigation appeared in the Ningxia Hui Autonomous Region and the Hetao area of the Inner Mongolia, with the implementation of measures directed at cultivating wilderness and guarding the frontier in north-west region.

With Luoyang as the capital of the Eastern Han dynasty, the economic center of China moved southwards. During this period, the number of storage-pond irrigation systems in the Huaihe River basin had increased substantially. Several storage-pond irrigation systems were built along the main rivers in Nanyang area, such as the Tuanhe, Tanghe, and Baihe rivers, and built along the main rivers in Runan area such as the Rushui River. Among these storage ponds, the Liumenbei built along the Tuanhe River, and the Hongxibei built at the Ruhe River were the most famous. The use of these storage-pond irrigation systems led the areas of Southeast Henan and West Anhui to richness and prosperity. Millet had once been the major cereal crop in the north, but wheat gradually grew in importance. Rice, imported from the south, was extended to the dry soil of the north. The soybean, in a number of varieties, proved to be one of the most important crops, and Chinese farmers gradually developed a sort of intensive agriculture. Soil was improved by adding manure and other soil amendments. Planting fields in carefully regulated rows replaced the fallow system. Great importance was placed on plowing and seeding at the proper time, especially in the fine-grained loess soil of Northern China. Fields were 
weeded frequently throughout the growing season. Farmers also knew the value of rotating crops to preserve the fertility of the soil, and soybeans were often part of the rotation. Irrigation became necessary as population pressure forced cropland expansion, and construction of irrigation works in many states beginning in the late Chunqiu period. These projects were built to drain swampy areas, leach alkaline soil and replace it with fertile topsoil, and, in the south and in the Sichuan Basin, to carry water into the rice paddies. The irrigation systems unearthed by archaeologists indicate that these were small-scale works presumably carried out by state or local authorities [10].

In the period from the end of Eastern Han dynasty to Sui dynasty (ca 220-581 AD), the previously united country had been divided and the regime changed frequently. The longest government lasted about 100 years, while the short ones could only last 10 or 20 years. Because of incessant wars, a large population of Chinese Central Plains moved southward with their agricultural technologies. Areas in the south of Yangtze River were mountainous but suitable for building ponds, thus storage-pond irrigation systems were popularly built there. Examples are the Chengongtang Pond in Yangzhou, Lianhu Lake in Danyang of Jiangsu Province; Jianhu Lake in Shaoxing, and Nanhu Lake in Yuhang of Chekiang Province [60].

\subsection{Archaic, Classical, and Hellenistic Civilizations (ca 800-30 BC)}

Past and present unpredictable precipitation patterns and geological variations of mainland Greece and the Aegean islands remain the "raison d'être" for the erratic nature of hydrology in the regions where the Greeks developed city-states. Since early dates, the existing evidence suggests developments of diversified and changing strategies for water management, including drainage and irrigation. With the emergence of the polis, the city-state in the Archaic age (ca 800-500 BC), the state formation involved controversial questions on how communities should manage and distribute water resources.

The division of Greece into a "dry" southwestern part and a "wet" northwestern part serves as a general and valid description of the regions' hydrology [62]. Early epic poetry-Homer and Hesiod-alluded sporadically to the complexities of cultivation and water management; however, these were not performed in a practical manner until the reforms of the Athenian magistrate (Archon) Solon in 594 BC. From that, there is a substantial evidence for state-induced legal action to secure "neighbors" access to water. If their distance to public water supply was more than "four furlongs", citizens were entitled to "fill a five-gallon jar twice a day" (Plutarch. Solon, 23.5). Clearly, this limited volume suggests the fulfillment of basic requirements for households and gardens rather than sustainment of large-scale irrigated farmland.

However, Solon's law makes it clear that Archaic and Classical Attica was a region of diverse hydrology, alluding to the fact that the present Greek peninsula experienced profound variations in rainfall-past and present $[63,64]$. In addition, frequent food crises triggered by local droughts or by the disruption of grain imports, due to overseas calamities, were recurring threats to the city-state's food supplies [65].

Crouch [66] documented how urban and rural developments from the Archaic through the Hellenistic period were intrinsically associated with water management and drainage. Moreover, he elucidated the dependency of urban and rural developments on the presence of karst areas, suggesting that many cities of the ancient world depended upon this geological structure for their water supply [66,67]. Crouch [66] also pointed to the importance of wastewater disposal, and indicated how drainage techniques and technology derived from agriculture could also be applied to clean urban infrastructure.

The pivotal question of when and where Greek societies developed irrigation techniques is however debatable. Hitherto scholars have convincingly argued that the kepos — the garden-developed from the archaic age onwards as a confined cultivated location where "small-scale" irrigation was practiced [7,67]. The epigraphic evidence from Classical and Hellenistic Athens and elsewhere frequently lists lease contracts of gardens as well as other forms of cultivated plots' management. 
Theophrastus ( $c$ a 371-287 BC) relates how gardeners cultivated a variety of plants, including the so-called potherbs, vegetables, but also flowers and other herbs. Thus, intrinsically, the 'kepos' potentially held wider range of crops than the modern concept of the kitchen garden [7,68-71]. Undoubtedly, in the Classical and Hellenistic periods, the ubiquitous kepos represented a location where manure, water and manpower were concentrated and it is borne out of the literature and epigraphic evidence that it was often located at or near the household (oikos).

It has been speculated, however, that a noticeable development surged in the Classical period where regular kepos-landscapes emerged [72]. According to Plutarch ( $c a$ 1st century BC), a larger area of Athens was named "The Gardens" and later tradition indicates that Boeotian Thebes was renowned for its gardens before it was destroyed by Alexander in 335 BC (Heracleides Creticus, 1.1-2 in [73]). The fundamental question is to determine whether large-scale irrigation was implemented to aid cultivation of garden systems or field crops. Possible locations of large-scale irrigation facilities in the Classical and Hellenistic periods were in Athens, Kopais, Eretria, Delos and Gortys (in Crete) and Metaponto and Herakleia (Greek colonies in the present-day Italy).

The material evidence suggests that the Minyan culture developed water works, irrigation and drainage in the 2nd millennium $B C$ to manage the effects of seasonal rainfall at the greater polje of the Lake Kopais [74-76]. Also, Minoan Crete probably saw an intensification of irrigation schemes at the Messara plain [20]. The question however is whether this early development left a lasting impact on the Hellenic water management for the following centuries.

The major challenge is to understand how large-scale irrigation and drainage may have developed in the Archaic and Classical periods to support regular field cultivation. First, available facts on the ground seem indicating development of such a scheme in the rugged "highlands" around 5th century BC Delos. Whether this development emerged in ca 4th century BC Southern Attica remains to be seen $[64,77]$. In effect, this example points to collection and storage of water by controlling the torrential autumn and winter rains, which made it possible to perform limited irrigation of large cultivated areas, predominantly terraced agricultural lands $[7,64]$. Terraces demanded intensive labor to be built and maintained, but at the same time, their construction improved soil depth and quality. This was done partly by removing the stones from the land, which were then used for building terraces and field retaining walls $[70,78,79]$.

Finally, the material and written evidence indicates the construction of large-scale irrigation systems at Metaponto of Magna Graecia and Gortyn, Crete, and a large drainage project at Eretria on Euboea in the late Classical-early Hellenistic period has been interpreted as a combined drainage and irrigation system $[7,80]$. The famed water works at Lake Kopais, allegedly clocked and malfunctioning, called the attention of Alexander the Great (Strabo IX 2.18; in [81]). Ostensibly, Alexander launched a project for its restoration but evidently, the project was never completed until the restoration and drainage of the lake in the 19th century.

\subsection{Roman Period (ca 30 BC-330 AD)}

Cereals were the most important part of the Roman diet and were grown during the rainy season, but required sufficient water to achieve adequate yields. Their production in Mediterranean environments was dependent on water availability through rain or irrigation, and was often associated with the fallow practices, where fields were left to rest in rotation. This agricultural practice was well known by Greeks and Romans [82], and such rotation was also applied to the cultivation of legumes, as reported by Pliny the elder (Nat. Hist., XVIII, 91). The crop yield varied with region and also with rainfall fluctuations. For these reasons, and also to ensure crop safety, irrigation was implemented when possible. For instance, Varro reports that in some areas of Etruria a single seed, with sufficient water, could make up to fifteen times its equivalent [83]. There, irrigation was an important element for agricultural practices during the dry summers. Drainage schemes for large areas, involving also runoff water reclamation, flood control, and navigation, were typical of the Hellenistic period. In Italy, the Etruscans used mainly underground galleries, while Romans preferred simple ditches or channels [84]. 
Romans did not add to science as Greeks did; however, they contributed tremendously to the practical application and deployment of engineering techniques [85]. Water was channeled from its sources, conveyed long ways, and distributed for irrigation of arable fields, orchards, vineyards, pastures, and gardens [86]. However, this method was rarely used for the wheat fields. Irrigation channels could be made of wood, clay, stone, or excavated into the ground. Romans also invented the Roman concrete (opus caementitium), which allowed the construction of long canals, very large bridges and long tunnels in soft rock [87]. For instance, these works were used for eleven aqueducts, which had a total length of about $350 \mathrm{~km}$ that ensured the supply of water to ancient Rome. Some of these channels are still working and used nowadays to supply the fountains in the city.

In the Italian peninsula, there was a widespread use of drains for irrigation, especially in orchards and pasture crops, more rarely for vineyards and olive orchards. In Central and Northern Italy drains were used for irrigation of crops and they often marked the limits of centuriation; i.e., the process or act of dividing land into centuries or equal areas undertaken by the Romans and known as Roman grid [88]. Emissaries of lakes, such as Lake Albano (Figure 9), were also used for irrigation and this and other water infrastructures were built by the legions (Figure 10). Among the eleven aqueducts, the Old Aqua Anio and the Aqua Alsietina were used only for irrigation and for feeding the Nymphaea because of their low water quality.

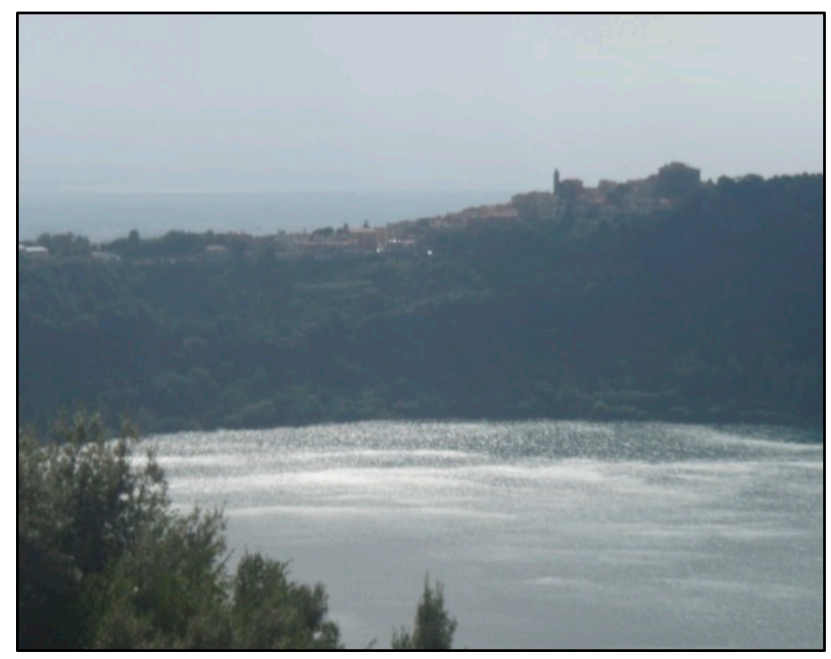

Figure 9. Lake Albano, Italy (Photo by M. Salgot).

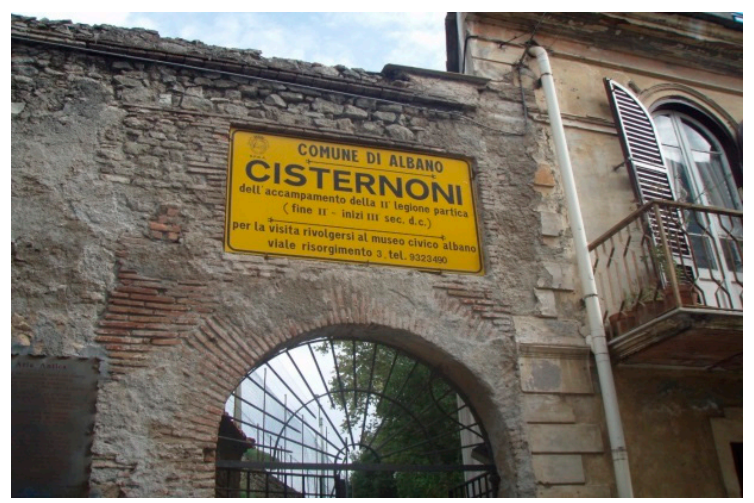

(a)

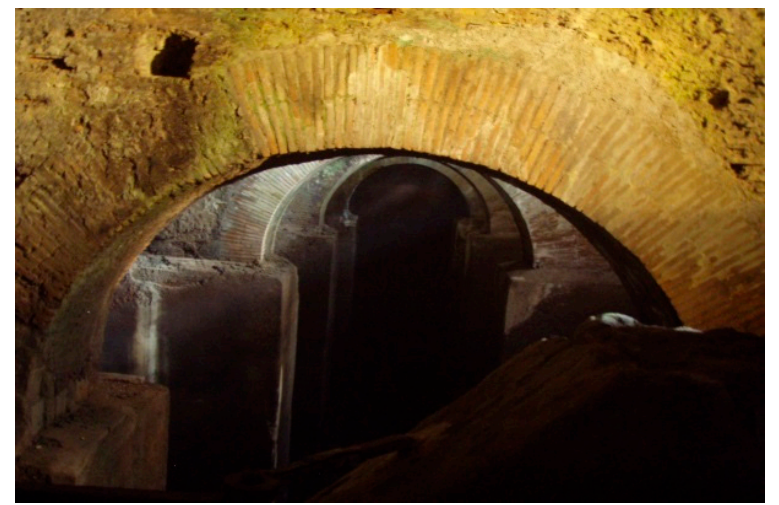

(b)

Figure 10. Cistern built by the II Legio Partica": (a) access, in the Albano municipality, Italy and (b) view of the interior (Photo by M. Salgot). 
Gardens were closely linked to irrigated agriculture [89]. Pomarium (apple tree garden) was a common feature of every agricultural property, irrespective of its size. It included several fruit trees such as almonds, hazelnuts, nuts, apples, pears, plums, figs, and quinces; with the later addition of other species coming from the East (e.g., cherries and peaches). The newly introduced species were planted interspersed among the existing ones and grafting was frequent. Columella $(V, 10,6)$ stressed the importance of this practice, which enabled farmers to improve the quality of native species through the introduction of stronger or most valuable varieties [90].

The Romans exported their skills as engineers not only throughout Italy but also all across the Mediterranean basin, including Gaul and Iberia, and especially along the African coast. Indeed, during the Roman Empire the cultivation of grains was extended even to deserts. In Libya, large areas, now abandoned, were enclosed by terraced walls along the edges of the hills, which, at the end of the wadis, collected the silt from floodwaters and the scarce runoff. The land bounded by these terraces was fertilized and the deposited moist layer often led to very high crop yields. These techniques of "dry or rain farming", although traditionally Saharan, were undoubtedly enhanced by the Romans. Generally, in North Africa and in the Eastern regions, Romans established permanent irrigation systems, which allowed for agricultural exploitation of otherwise arid and unproductive territories [91].

Research and examination of aerial photos make it possible to recognize the exceptional breadth of areas served by irrigation systems, in some cases related to the centuriation. Water from natural or man-made watercourses and other sources was collected in canals, with parallel paths, concentric or fan in shape. In some cases, the basins were constructed either isolated or arranged in series along the slopes, resulting in terraces, as in the case of the impressive facility of Oued Ogrib, in Algeria. The canals could be excavated into the ground or contained on the sides of the land, possibly by using retaining walls made of stones and gravel; they were generally small in size, however there are examples of larger size (e.g., in the plain of Caesarea (now Israel), a $27.5 \mathrm{~m}$ wide and $0.46 \mathrm{~m}$ deep canal. In other Regions of the Roman Empire (e.g., Egypt and Syria), Romans also improved the irrigation systems, using the existing structures in some cases and in others building new canals (e.g., Trajan's works). Furthermore, they introduced technical and administrative changes such as tax incentives, operating rules, and cadastral divisions linked to irrigation systems [90].

The existing regional differences in geo-morphology and river water availability had a significant impact on the distribution of irrigation techniques across the Near East in the Roman period. The distribution of irrigation canals and qanats was mutually exclusive, as illustrated in Figure 11 [92]. Irrigation technologies were inextricably tied up in the complex and shifting relationships between technology, social factors and environmental challenges. Sharing the existing water availability between urban centers and agricultural fields illustrates the fact that agricultural concerns coexisted with broader social and environmental challenges, and the unpredictability of water supply in the region played a role in tightening these relationships [92].

Finally, when the Sassanian Shah Shapur I defeated the Roman emperor Valerian (ca 250), he is said to have ordered the captive Roman soldiers to build a large bridge and dam stretching over $500 \mathrm{~m}$. Lying deep in Persian territory, the structure exhibits typical Roman building techniques, and became the most eastern Roman bridge and Roman dam [93]. Its dual-purpose design exerted a profound influence on later Iranian civil engineering and was instrumental in developing Sassanid water irrigation and management techniques. 


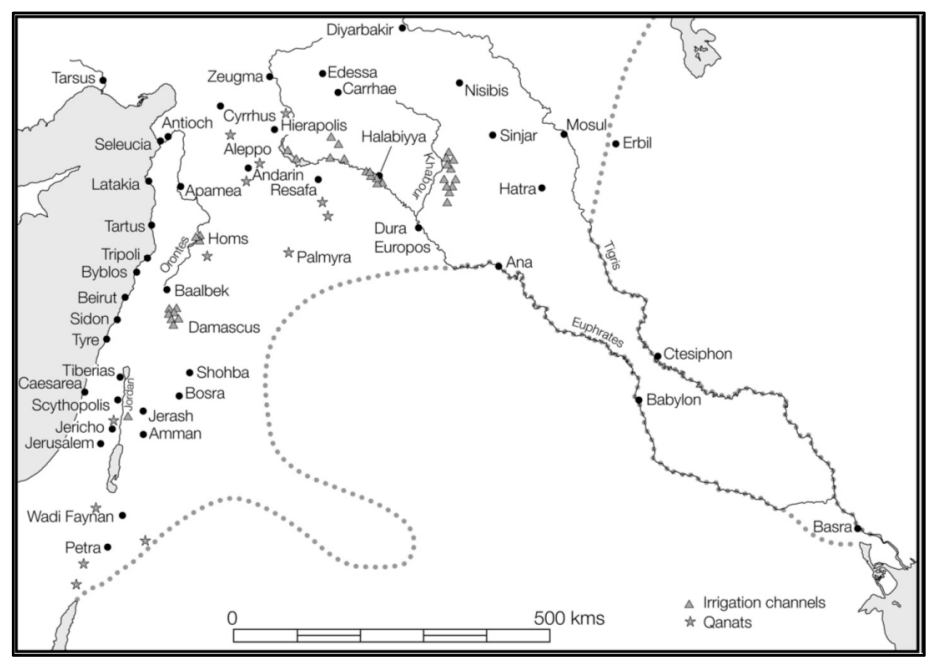

Figure 11. Map of the near east in the Roman period, showing the distribution of irrigation channels (triangles) and qanats (stars) (prepared by Alison Wilkins [92]).

\subsection{Other Historical Civilisations}

\subsubsection{Urartu Kingdom}

Advanced water management emerged in Anatolia during the Urartu Kingdom, which rose to power $\mathrm{ca}$ mid-9th century BC. Belli [94] performed a systematic study in eastern Anatolia to identify Urartian dams, reservoirs and irrigation systems, with particular focus on the agricultural infrastructure of the Van Lake basin. In the Van basin and its surrounding areas, located in the western part of Anatolia, irrigation canals and dams dating from the time of the Urartian Kingdom (ca 840-590 BC) can be still observed. This Kingdom was located in the highlands of Eastern Anatolia, the Ararat plain of Armenia, and in the present northwestern Iran. This region is located on an active tectonic zone, but earthquakes have not affected its irrigation systems. There are very few places in the world with a water supply and conveyance infrastructure that has been in operation for ca $2700-2800$ years. That is why the Urartian Kingdom is named the greatest Hydraulic Civilization of Anatolia and Asia [94,95]. The tradition of building water works began with the Hittites and Assyrians, which used to live in Urartian/Urartu and thrived during the medieval and Ottoman times in Anatolia. The Urartian thus represent an important connection in the development of agricultural irrigation and dam construction in Anatolia up to the present day. The Urartu dams built nearly three thousand years ago on streams and small rivers are the forerunners of the modern dams on the Euphrates and Tigris rivers in Eastern Anatolia today [94,95].

One of the most interesting sites relating to the development of Urartian water facilities is Lake Aygir in northwestern Van. Here, terracotta (clay) water pipes and stone channels were laid down to convey water out of the artificial lake [96].

The irrigation systems set up by the Urartians made use of surface water from one of two existing systems. The Menua or Shamram Canal, built by King Menua around 800 BC conveyed water for downstream irrigation (Figure 12). To our knowledge, this canal is the only irrigation canal in the world that has been in continuous use for nearly 2800 years. The second is irrigation supplied by water from Lake Keşiş (Lake Rusa) and the smaller dam lakes in the vicinity. Lake Keşiş, which was dammed by Rusa II (680-654 BC) and lies east of Van at an altitude of $2890 \mathrm{~m}$, stored sufficient water for meeting the needs of the new kingdom capital, Rusahinili, and its surrounding areas to last through the summer months. About $20 \times 10^{6} \mathrm{~m}^{3}$ of water could be stored in the still-existing dam. 


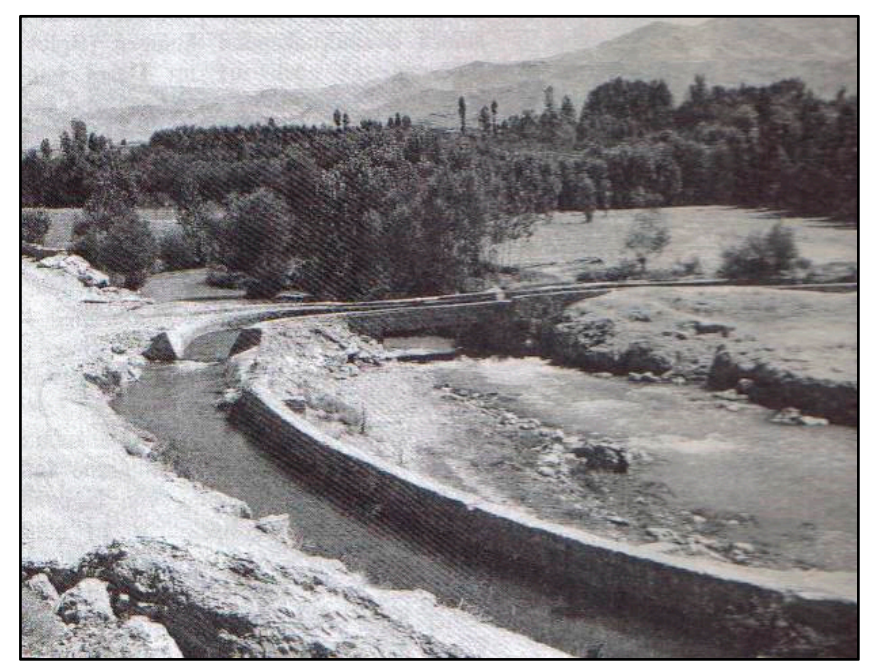

Figure 12. View of ruins from Menua canal [97], which still conveys water from Lake Keşiş [94].

\subsubsection{The Levant and Beyond}

Water diversion devices for irrigation and other purposes have been used in various other locations in the Fertile Crescent. For instance, in Yemen, the oldest dam, constructed in masonry over a length of about $500 \mathrm{~m}$, was built in ca 600-500 BC for flood protection and irrigation [10].

North of Mesopotamia, in western Persia and eastern Turkey, farmers began construction of elaborate systems for extracting groundwater for irrigation about 2500 years ago [98]. The system, called "qanat", consists of a series of wells for extraction of material, 20 to $30 \mathrm{~m}$ apart, connected at their bottoms by a tunnel with controlled slope, in order to tap groundwater without lifting devices. The technology extended with Persian rule during the period ca 550-331 BC, from the Indus to the Nile River basins [10]. Further expansion took place in the Mediterranean basin, Egypt, Afghanistan, the Silk Road, oases settlements of central Asia, and Chinese Turkistan [99]. During the Roman-Byzantine era, large numbers of qanats were constructed in Syria and Jordan. The Romans also used qanats as subterranean parts of aqueducts, forming complex water transportation systems, in Tunisia and Turkey. Another major expansion of the technology in North Africa, Cyprus and Sicily took place during the early Islamic period.

The early developments of irrigation in Egypt and Mesopotamia extended first to North Africa and the Mediterranean under the Carthaginians (Phoenicians), during the $c a$ 9th century BC, and then to the south under the Greco-Roman Empire. The latter focused on harnessing existing water sources and rainfall water collection, with structures such as blocks of masonry dams, reservoirs and cisterns for rainwater, canals and aqueducts, and dams made of dry stone to divert water for irrigation.

Solomon's Pools in Bethlehem, Palestine, are three large catchment reservoirs, each of around $160,000 \mathrm{~m}^{3}$, built with stone and masonry between $c a 1000$ and $30 \mathrm{BC}$ in two stages. Ancient aqueducts in the area collected water from springs and conveyed it to the pools. Some of the springs with channels are still used for irrigation today.

\section{The Sui, Tang, and Song Dynasties in China (581-1127 AD)}

The Tang dynasty, established on the basis of the Sui dynasty that reunified China, represented a period of brilliant ancient Chinese civilization. Before the An Lushan-Shi Siming rebellion in 755 AD, with the unity and prosperity of the country and regime stability, irrigation in China underwent further development, especially in the Yellow River basin. Along with the spread of rebellion, the Tang dynasty experienced a process from prosperity to decline. Not long after that, several separatist regimes were set up by force of arms. It was the same situation in the following Five Dynasties and Ten Kingdoms. There was a long-term confrontation with Khitan, Dangxiang, and Nuchen in the Northern Song dynasty, and the emperors of the Southern Song dynasty were all contending to exercise 
sovereignty over only a part of the country. Incessant war spread all over the middle and lower reaches of the Yellow River in this period, but the regime was relatively steady in South China because of the effective defense of the Yangtze River, which was viewed as a natural moat, enabling further economic development demands in South China. Thus, the pond-canal polder system in the Taihu Lake and the Yangtze River basin, and projects limiting seawater intrusion and restoring freshwater in the southeast coast emerged and gradually grew as required.

The pond-canal polder system in the Taihu Lake basin was built during the Tang dynasty and was more advanced than the original fragmented water reclamation system [100]. Natural rivers in the basin were used to develop the ponds and canals, with the excavated soil used to build the dike, so that farmlands were enclosed. Inside the polder, locks were installed on the dike to enable irrigation and drainage. With the building of Taihu Dike and the seawalls, the pond-canal polder system was gradually improved. However, shortsighted reclamation in the Song dynasty destroyed the original irrigation and drainage canal systems, leading to large polders being divided into small pieces. Polders in the lower reach of Yangtze River were developed rapidly during the Tang and Song dynasties. Because of the fairly large hydraulic head of this region, their dikes were very high.

Projects for preventing seawater intrusion and storing freshwater in the southeast coast played an important role in the rapid development of local economy. The infrastructures were mainly consisting of the flash dam and the canal. The flash dam was used for warding off tides and storing freshwater from the upper reach. The canal was used for diverting stored freshwater and conveyance to farmland. Among these projects, two are most famous: one is Tashan weir, located along the Yinjiang River of Yin County, in the Chekiang Province; the other is Mulanbei, located along the Mulan River of Putian County, in the Fujian Province. With all these water conservation projects, the Taihu Lake basin and the Yangtze River basin gradually replaced the Yellow River basin as the economic center of China during the Tang and Song dynasties. Bamboo pipes were utilized as inverted siphon during the Tang dynasty [101], and then used for irrigation. These pipes are illustrated in Figure 13. The proverb "when there is a bumper crop in Taihu Lake basin, the country will be free from hunger" vividly reflected this change.

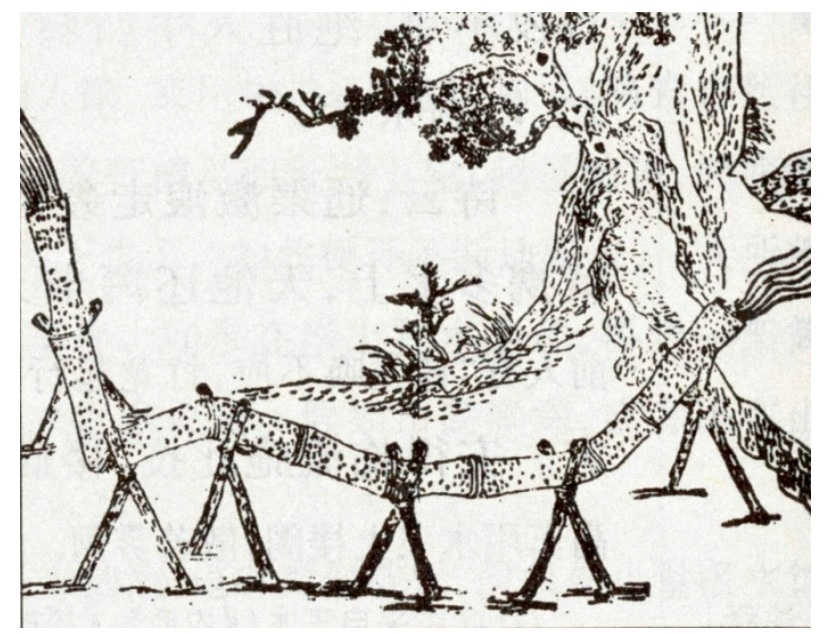

Figure 13. Bamboo pipes.

\section{Late Pre-Columbian Civilizations}

\subsection{The Aztec Civilization and its Precursors (ca 1200-1500 AD)}

Recent awareness of the need to address water and food security as a joint issue for achieving sustainable development [102] runs alongside the need to recover nutrients from treated wastewater re-used for irrigation. Recovery of nutrients as fertilizers during agricultural irrigation is being promoted as a recent discovery in some developed countries. However, these goals were already 
achieved by ancient agricultural techniques such as the one of chinampas. The chinampas were a crop-growing method used in the Valley of Mexico before Aztec times [103] and extensively developed by the Aztec from ca 1350 to 1500 AD [104]. The chinampas are a UNESCO world heritage center since 1987. They are a model of sustainable agriculture because of their high productivity, use of waste as fertilizer, beneficial impacts on local fauna, responsible use of natural resources [103], and recovery of nutrients.

Around the 12th and 13th centuries, several civilizations settled in the Valley of Mexico, in an area of around $9600 \mathrm{~km}^{2}$. This Valley is located in the center of present Mexico at an altitude of $2430 \mathrm{~m}$ a.s.1. and is surrounded by mountains. The climate is temperate humid in the south (1200 mm year $\mathrm{mof}^{-1}$ rain) and temperate dry in the center and the north (800 $\mathrm{mm} \mathrm{year}^{-1}$ of rain). The rainy season is well defined and lasts from May to November. These are the conditions for which irrigation is necessary to produce food all year round.

The Aztec people ( $c$ 1200-1500 AD) was the most important of those civilizations and was the head of an empire comprising around 400 towns [105]. In 1519, before the Spanish conquest, the population of the Valley was very large, estimated to be 1.3 to 3 million inhabitants [106]. This population presented a high demand for food and water, a situation forcefully linked to the development of innovative solutions for both these supplies.

During the Aztec times, the valley was covered by several lakes—some of them were saline-and wetlands, marshlands, springs, and perennial and permanent rivers [107] were also present. The Aztec developed several hydraulic solutions to separate saline water from freshwater, control lake levels and floods, supply water for municipal use, as well as consciously feed water for agriculture [108]. A map of the lakes of Mexico Valley at the Aztec time showing the area occupied by the chinampas is presented in Figure 14. Because of the particular geography of the area, the Aztecs developed a complex and efficient management of the water [109].

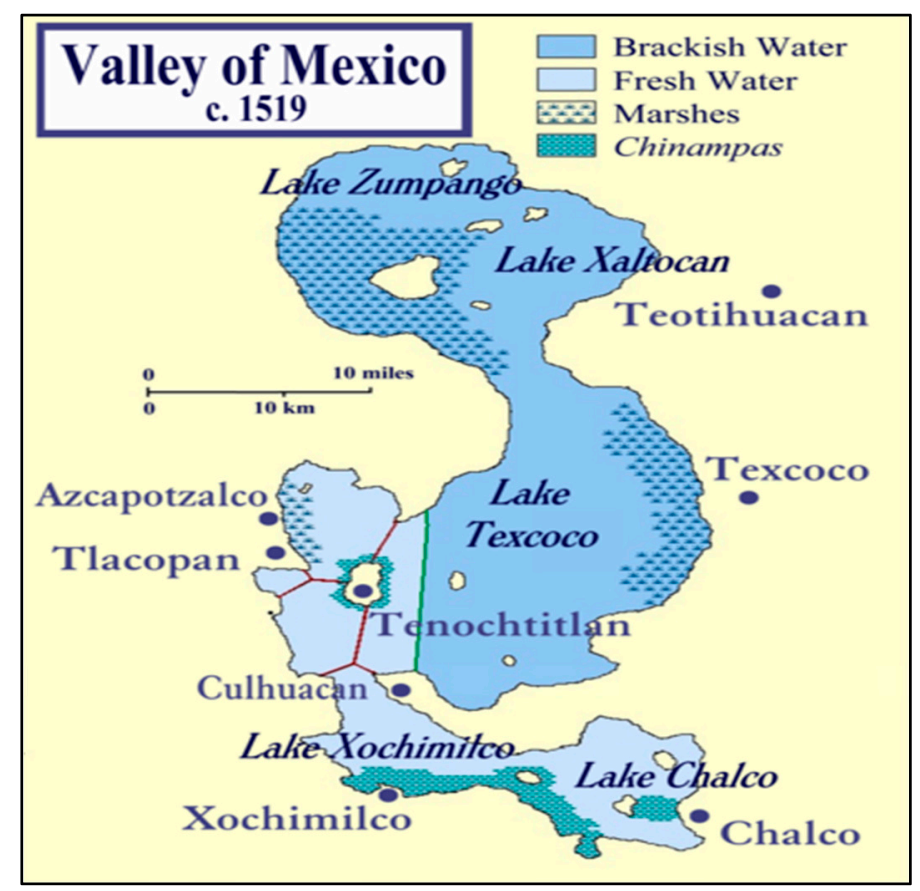

Figure 14. Lakes of Mexico Valley at the Aztec time, with areas occupied by the chinampas (adapted from [107]).

One of their main achievements was the mentioned chinampas. The study of the chinampas has been conducted through techniques such as aerial photographs [103,104], archeology, investigation of historical documents, and more recently computer programs that integrate geographical and archeological data [109-112]. 
The chinampas occupied at least $1200 \mathrm{~km}^{2}$, i.e., $120,000 \mathrm{hm}^{2}$ [104], and were enough to produce the food to feed the entire population of the Valley. Thus, just prior to the Spanish conquest in 1521, the chinampas supported about 10-18 persons per hectare. The most productive chinampa area of the Valley, located near the Xochimilco-Chalco Lake, was used to feed the high social classes in Tenochtitlán [113].

The chinampas (Figure 15) consists of small manmade islands for growing crops, placed on lakes or marshes, 40-100 m long and 2-9 m wide in strictly rectilinear and parallel plots surrounded by canals [112]. The soil of the chinampas is continuously renewed by adding sediments and mud from the bottom of the waterways over the previous surface to maintain their height and fertility. It has been estimated that $10,000 \mathrm{hm}^{2}$ of chinampa fields could provide at least half a million people with their staple food [113]. There are some inaccuracies regarding the details of the original use and productivity of chinampas (Figure 14). This is due to the bias of historical sources and the difficulty of conducting archeological investigations on the Valley of Mexico, given that it is now the urban area of Mexico City [104]. However, it is still possible to get a picture of the role the chinampas played in the Aztec civilization. Chinampas are considered the most productive and ecologically sustainable form of agriculture in pre-Hispanic Mesoamerica, as they recycled nutrients and increased biodiversity [112].

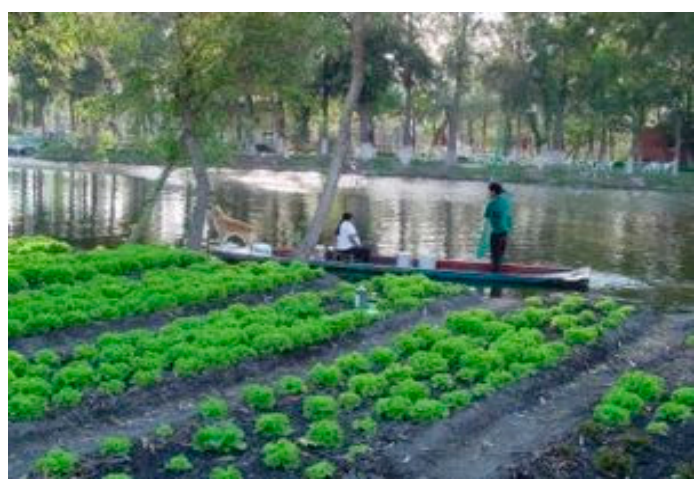

(a)

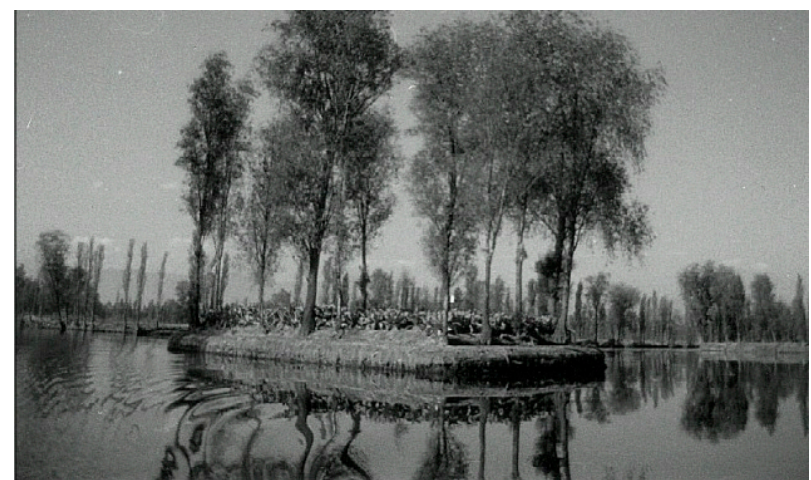

(b)

Figure 15. Chinampas: (a) View of current plots and (b) view of an entire chinampa (http://trabajosnakos22. blogspot.fr/).

The site of a new chinampa was selected using a long pole or based on the remains of an old one. The foundations were built by anchoring strong reeds to the roots of native cypress trees [113]. Afterwards, mud was piled atop the reeds as a base and then alternate layers of chopped algae, tule, and mud were laid making the bottom of the chinampa very porous, thus allowing water flow and permitting capillary action for watering the crops. The topmost layer was made with mud from the bottom of the canals, manure and human waste to make it high in nutrients $[111,112,114]$. The height chinampas were raised above the water is estimated to be between 0.2 and $0.7 \mathrm{~m}$.

Seeds were not planted directly in the chinampas; instead, they were grown on rafts, back yards or 'almácigas'. Almácigas were customized environments consisting of low terraces at the water body's edge. They were perpetually moist and filled with ultra-nutritious sediments scooped from the bottom of the canals. When seedlings were mature enough, the healthiest were selected and planted on the chinampas by cutting a cube of the soil around them and placing them on a spot preconditioned with canal mud and water plants on the chinampa [115]. The soil of the chinampas was kept rich in nutrients by periodically spreading manure, water algae, human excrements and mud from the surrounding canals.

There are several reasons for the high productivity of chinampas. First, the practice of growing seedlings and then transplanting only the healthy ones to the chinampas led to higher yields since the space and resources were not wasted on unhealthy plants, and the crop cycle was shortened. Secondly, 
the use of local organic matter to fertilize the plants meant that the crops were nourished from richer soil [104].

The chinampas were also efficient at using water. Since the chinampas are narrow strips of land perpetually surrounded by water, irrigation was not necessary. Consequently, time and energy were saved and the cultivation was possible all-year round, including the dry season. It is also important to highlight that chinampas allowed plants to be moist at root level (capillary rise), therefore avoiding the water loss occurring when watering plants from the top. In addition, chinampas promoted the growth of local fauna, being the patches of land in the lake served as resting places or as habitats for several animals; and promoted the growth of populations of migratory birds, fish and axolotl [111].

Nowadays it is still possible to visit $1000-2000 \mathrm{hm}^{2}$ of chinampas at the UNESCO world heritage center (established in 1987) on what remains of the ancient Xochimilco Lake located in the southern axis of Mexico City's urban sprawl. These chinampas are used for the cultivation of corn, vegetables and flowers commercialized in Mexico City and use the same ancient procedures for production.

\subsection{The Inca Civilization (1438-1533 AD)}

The Inca or Inka (Quechua: Tawantinsuyu) was the largest empire in pre-Columbian America. The administrative, political and military center of that empire was located in Cusco (or Cuzco in Spanish) in the modern-day Peru. The Inca civilization arose from the highlands of Peru sometime in the early 13th century, but the Inca Empire was short-lived (1438-1533 AD). The Incas used a variety of methods, from conquests to peaceful assimilation, to incorporate a large portion of western South America, centered on the Andean mountain ranges.

Andean farmers faced the problem of two dramatically different environmental regimes: the coastal desert that receives minimal rainfall, and the highlands that receive substantial rain that drains through river valleys and finally passes into the coastal plain. In order to control, divert, and redistribute river water, ancient Andean peoples built a series of canals that grew in scale as population densities rose and a more sophisticated arrangement was needed to support larger and more complex societies. The canals began in the valleys but soon extended into the coastal desert, greatly increasing the areas of arable land suitable for farming.

Fields in the upper reaches of river valleys had the greatest access to water, while the fields at the ends of the canals had water only during the rainy season. Netherly [116] classifies Andean farmlands according to their access to water and productivity. In her system, Category 1 land may have permanent access to water, whether through irrigation or natural water abundance. Category 2 land is irrigated and produces two crops annually, whereas Category 3 land is flooded annually, like the farms along the Nile River, and produces a single annual crop. Finally, Category 4 land is irrigated only during the part of the year when water is most abundant, and produces a single crop each year. Each of these land types expands the naturally arable land, so that Andean agricultural farmers were able to move from farming only the riverbanks to successfully producing an annual crop in the desert at the edges of the canal systems.

By the rise of the Inca Empire, these canal systems were controlled by elites at several levels, ranging from valley-wide distribution to a corporate groups' control of local water allotments. The Inca took an existing system and added a second level of political control, instituting a moiety system that doubled the levels of socio-political control over this elaborate system. The Incan imperial hegemony operated by choosing two new local authority figures from the conquered indigenous elite to administer tribute and supervise the allotment of water and maintenance of the canals. While this system appears to disrupt local socio-political organization, it adheres to Andean practice. The new moiety division drew on an existing Andean framework, whereby the world is a series of opposing but complementary halves [117]. What we know of this system comes primarily from post-Conquest Spanish chronicles, but it seems that the existing Andean system continued largely undisturbed into the historic period, with local elites at different levels of political power controlling each step of the water allotment process. 
The system governing the canals can be classified as one of the three types: canals controlled by one polity, canals controlled by multiple polities, and canals that connected two valleys [116].

\section{Medieval Times ( $c a$ 330-1500 AD)}

The concept of medieval times is basically applied to the civilizations related to Europe and the Mediterranean, which implies that the rest of the world (present America, China, and India) is somewhat independent from this definition. In this limited part of the world, water-related history is more known than elsewhere due to the presence of historians who have been finding, recovering, elaborating and publishing documents on the subject.

Concerning irrigation, since it developed in places where growing crops required supplementary water in addition to rainfall, there is an additional geographic limitation: the arid and semiarid climates are the only ones included in the work and will be a center of the attention for this section. As such, Northern Europe is excluded because irrigation was mainly not needed there. This difference was evident, even in the type of plough used (soil differences were also important) and the animal force (ox instead of horses) as explained by [118]. The development of agriculture was related with the need to supply food to an increasing population with the same amount of land. Barnebeck [118] reported that economy appears to relate to agriculture in the moment when farmers were supposed to supply food to a certain number of persons not living on the agricultural lands, and this is when agricultural water management matters.

Populations did not increase linearly during the medieval ages in Europe because of recurring local, regional or continental wars and epidemics, including the bubonic plague or Black Death that ravaged Europe on several occasions. Malaria also caused many problems in relation to water management [119].

The irrigation practices during those times were an evolution of previous techniques implemented by Greeks, Romans, and Arabs. While in the north of the Mediterranean Basin medieval times was a dark period with little technological progress, the Arab domination of the basin expanded irrigation technologies from the east to the west of Southern Europe [120]. Some limited technology survived in the north however, mainly due to the knowledge maintained in monasteries of religious orders. The crusaders also helped to transfer Arabic science and technology to the Christian world. In fact, due to their expansion throughout the Mediterranean, the ancient irrigation systems were implemented in the dry lands of North Africa and in the arid part of the Iberian Peninsula, as well as in the south of the present-day Italy and the large Mediterranean islands.

During a few centuries, several Italian city-states dominated the Mediterranean Sea, sometimes fighting, other times collaborating. These cities aimed at extending their possessions and establish rule in other countries or cities [66]. Among them, Venice and Genoa established commercial routes and ruled over foreign territories, e.g., parts of Crete, Sardinia, south of Italy, and Sicily. The commercial exchanges and domination favored technology transfer including irrigation. Apart from "high-technology" facilities, small solutions were maintained in the entire Mediterranean area, e.g., the cisterns, still in use in many places. "Subperiods" can be defined in medieval times, in relation with the dominating states or towns, as indicated in the next two sections.

\subsection{The Byzantines and Other Civilizations (ca 330-1204 AD)}

Since the Eastern Roman Empire, also known as Byzanthium, continued the Roman civilization, the technologies in use for water management did not change in this part of the Mediterranean basin, where the remnants of water infrastructures using Roman or older techniques are common. Some of the related features remain visible, like the public baths or hammams, maintained and utilized by the Arabs throughout the centuries, and afterwards backed again by the Turkish domination of the eastern part of the Mediterranean in later historical periods. Remnants of irrigation systems (rain farms), cisterns and other features from Nabatean and Byzantine periods can still be seen in several places, e.g., in En-Avdat, near the Ben-Gurion University in the Negev in present-day Israel [121-123]. 
The Arab conquests of the 8th century and the later initiated a great era of agricultural revival, which resulted in an intensification of irrigation practices throughout the Islamic world. Technologically, the civilization of Islam was a synthesizing one, just as the prior Roman Empire. The Arabs may have invented little by themselves, but they preserved, refined, developed, and intensified the technological practices of the ancient world. The spread of Hellenic scientific ideas to the West of the Mediterranean through the Arabic language is well known, and a parallel process can be described in the preservation and extension of ancient Iranian, Babylonian, and Nabataean agricultural techniques [124]. The westward spread of irrigation technology across the Mediterranean followed a pattern that might also serve to illustrate the diffusion of eastern concepts of water distribution and measurement [120].

With the spread of the Islamic Empire westward in the Mediterranean Basin, agricultural and irrigation methods and techniques were brought into conquered areas. The rulers of Al-Andalus (Andalucía, Spain) and many of their followers were of Syrian origin, and the climate, terrain and hydraulic conditions in parts of southern and eastern Spain and North Africa resemble those of Syria. Therefore, it is hardly surprising that the irrigation methods-technical and administrative-in Valencia (Spain) closely resemble the methods applied in the Ghuta of Damascus [120].

There is a unanimous consensus among historians that the present Spanish irrigation systems of Valencia, Murcia and Andalucía are of Muslim origin [125], as well as those in the South of Portugal. In 1960, a celebration was held in Valencia commemorating the "Millennium of the Waters", which expressed public recognition of the establishment of the irrigation system, and specifically of the Tribunal of Waters (Tribunal de les Aigües) during the reign of "Abd al-Rahman III". It should be noticed that the Tribunal of Waters is a UNESCO world immaterial heritage since 2009. Water distribution and irrigation in the Balearic Islands also have Arab origins as is the case for Palma de Mallorca (Madina Mayurqa) where many 'sequias' (siquias or small canals) still remain [126].

As an example, it is worth noting that there are many remains of historical irrigation systems of Muslim heritage still in operation in Spain, as is the case in the watershed of the Poqueira river, in the high Alpujarra, Southeast Spain. The area of the watershed is $9000 \mathrm{hm}^{2}$ and its elevation varies from $400 \mathrm{~m}$, where the Poqueira River joins the Guadalfeo River, to $3479 \mathrm{~m}$ at the peak Mulhacén, the highest summit in the Iberian Peninsula [127]. The irrigation canals, known as acequias, were excavated; however, the history of the acequias is uncertain and to some extent speculative. Documents from the Early Modern Age improved our understanding of the layout and organization of the acequias network. The longest acequia is the Acequia Nueva (Figure 16), with a total length of $10045 \mathrm{~m}$, a conveying capacity of $4591 \mathrm{~s}^{-1}$, and an irrigable area of 827 ha. The smaller acequia is the Acequia Cachariche, with less than $5 \mathrm{~km}$ of length and a conveyance capacity of $2431 \mathrm{~s}^{-1}$, as indicated by [128].

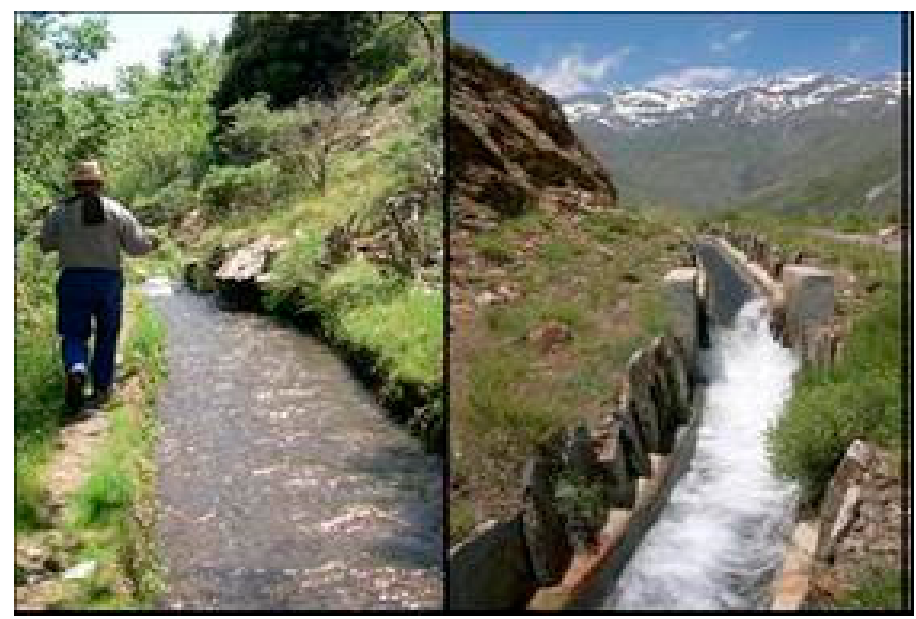

Figure 16. Views of the Acequia Nueva, watershed of the Poqueira River (adapted from [128]). 


\subsection{The Non-Arab Europe}

The Arab armies were halted in their northward expansion in the early 8th century by the army of the Franks, near Poitiers, and later on, they returned to the south and ruled an important part of the Iberian Peninsula for more than seven centuries. While in the Christian Western Europe science and knowledge were mainly sheltered and survived in Monasteries, the rest of Europe entered a time of technical obscurity. For the monastic orders to survive, it was extremely important to have water to establish a monastery and keep it active. The requisite of sufficient water availability was so strict that the monastery should be rebuilt in a different location if the original site did not have sufficient or reliable water supply, or if it was exposed to flooding hazards. For example, the bylaws of the Benedictine order in its Chapter 66 recommended that the monasteries of the Cister (a branch of Benedictines) must have sufficient water supplies to be independent from external resources. Thus, the majority of the monasteries of the order were located in valleys, where usually plenty of water was available and the water level was high enough to allow direct access and use of the resource. Water was so important that the church could even be rebuilt in another location in the precinct in order to avoid interference with water management. An additional requisite was the preservation of buildings from possible flooding, and specific defenses against flood water and drainage channels were usually installed. If needed, riverbeds could be diverted to protect monastery infrastructures [129].

By the end of the medieval period, several Mediterranean states started developing as independent town-states and to guarantee food supplies, they re-developed, recovered or constructed brand-new irrigation and drainage infrastructures to control seasonal floods and cope with droughts. In this respect, great advances were also made. It should be noted however, that in medieval records there is no clear indication of distinction between irrigation systems and drainage; the two purposes were related and, where possible, combined. However, the conditions were not equally favorable everywhere [130].

Thereafter, references in Piedmont about partnerships for the maintenance of irrigation works were found. Shortly after, the first record of permanent water meadows or marcite appears in 1138 in the present-day Italy on the estates of the Cistercian abbey of Chiaravalle near Milan (Figure 17). South of the Po River, in Emilia, where water supply was dependent on the irregular Apennine streams, irrigation was more limited and subjected to state control. However, here too, by 1330, in the territory of Parma, Modena and Bologna, it had begun to encroach on farm and meadowland. With irrigation and drainage, dykes, canals and ditches, medieval farmers and engineers were preparing changes in Northern Italy, far exceeding anything achieved in Etruscan or Roman antiquity [131].

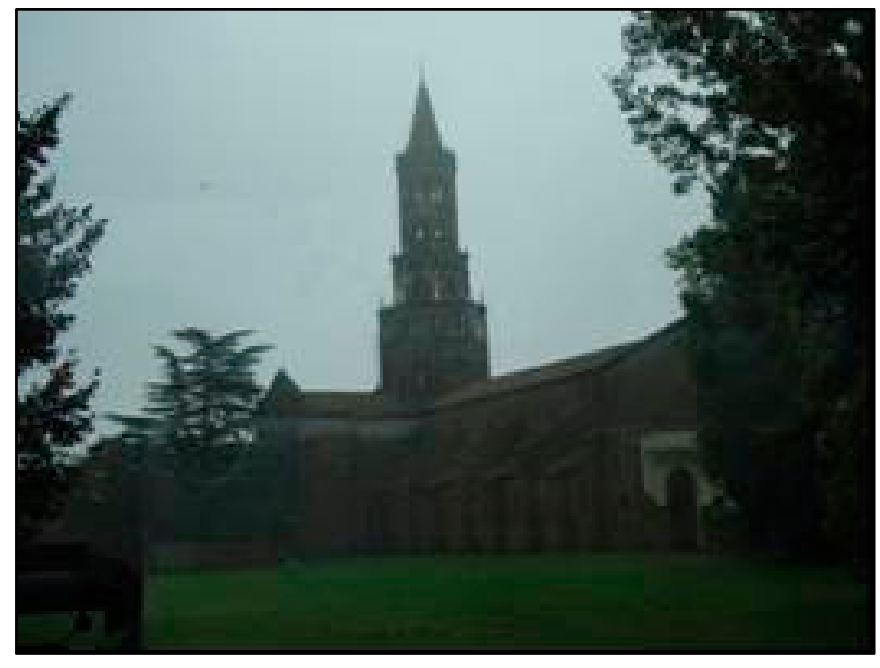

Figure 17. Chiaravalle abbey, near Milan, Italy (photo by M. Salgot).

In the hills and highlands particularly, irrigation was restricted, as it still is today, to certain privileged areas where easy access to markets encouraged limited seasonal irrigation of market-gardens 
and orchards. Irrigation practices are found of this form in present Italy by the 13th and 14th centuries near several Tuscan towns and on the slopes of coastal Liguria, as well as in the upper Adige valley. In the arid Val d'Aosta there may also have been some irrigation of cereals [131]. In other places of the Mediterranean, where towns were developing an industry (e.g., textile), water was brought from different distances to feed the population, industry and agriculture, sometimes with huge problems of coexistence of the different uses. This was the case, for example, in the medieval Barcelona, Spain.

\section{Late Chinese Dynasties}

A united country and steady regimes during the Yuan, Ming, and Qing dynasties led to economic development and population growth in China. This encouraged substantial development of irrigation with system planning being more scientific, technologies more mature and project styles more diversified, in addition to facilitating the expansion of irrigation throughout the country.

During this period, the polder concepts and technology in the Taihu Lake basin greatly improved. The polders in the Poyang Lake and Dongting Lake of the Yangtze River basin and Dike enclosure at the Pearl River delta all entered the large-scale development period, which led the Yangtze and Pearl River basins to become economic centers of China. In Northern China, ancient irrigation districts in the Yellow River basin, such as Ningxia and Hetao, further developed. Farmers in semi-arid areas such as Hebe, Shanxi and Shaanxi and other provinces, excavated wells and springs with the purpose of using groundwater. The Ming and Qing dynasties adopted the practice of stationing troops that would cultivate and guard frontier areas as an important state policy for developing border areas and consolidating frontier defense. This made the irrigation in remote areas advance with unprecedented development. Among these irrigation projects, karezs (qanats), mainly distributed along the Turpan Basin and Hami in Sinkiang, were well established irrigation systems. A karez mainly consisted of the shaft, the underground blind drain, the canal and the end pond. Shafts were laid out along the terrain from higher to lower elevations with the depth thereof changing with the ground elevation gradient. A blind drain was developed at the bottom of shafts so that these could be connected to divert water out of the drain. Water flowing from the drain was stored in ponds, and finally delivered to the farmland through canals.

The Sinkiang area was characterized by a dry climate with high evaporation. With water flowing through the ground blind drain, the high evaporation losses associated with general water diversion works could be avoided, so that precious water resources could be effectively spared and subsequently used. In addition, the development of Tien Lake water conservancy project in Yunnan Province made Kuming a beautiful and prosperous city in southwestern China.

\section{Irrigation in Modern Times}

\subsection{The Ottoman Period (ca 16th Century-1923)}

As indicated before, during the early Islamic period irrigation was further developed and up-scaled to large schemes fed by long water conveyance canals. This was done by the Abbasid dynasty, which was headquartered in Baghdad (762-1258 AD) [12]. A major expansion of the qanat technology to North Africa, Cyprus, and Sicily also took place during this period.

Afterwards, Turks founded the Ottoman Empire in 1299 near present-day Bursa. The Empire expanded its territory, eventually covering a large part of Europe, the Middle East and North Africa at the end of the 16th century. The Ottomans constructed important engineering works in that part of the world, and numerous bridges and irrigation systems, including dams and canals, can be found even today in Algeria, Syria, Anatolia, and the former Yugoslavia. The particular techniques Ottomans used to build those engineering structures are not known, unfortunately, as they did not report or publish their knowledge so that one could be aware of solutions used for solving different kinds of problems. The early Ottoman dams were used to store water for domestic purposes, and special devices were used for delivering water to users [132]. 
The Sultan Mehmed II (1451-1481) commanded that urgent repairs be made to the existing water systems. During his reign, a water department was established, underscoring the relevance of water supply to the Ottomans, as it was for earlier civilizations. During the reign of Mehmet II's son Sultan Bayezid II (1481-1512) the Bayezid waterway was built and during that of Bayezid II's son Selim I (1512-1520), various and diverse waterworks were constructed. Aqueducts in the form of arched bridges had been used since Roman times to convey water across valleys and streams, dividing two areas of high grounds so that water did not lose head. During the reign of Süleyman the Magnificent (1520-1566), the former Roman water system, which conveyed water from the Belgrade Forest to İstanbul, was rebuilt with additions and extensions by Mimar Sinan and became known as the Kırkçeşme water system. Preliminary solutions for the water demand problems of İstanbul were handled with the construction of 40 fountains in Fatih Sultan Mehmed (also known as Mehmed the Conqueror) era. This duty was given to Mimar Sinan in the era of Sultan Süleyman. In this period, new water aqueducts were constructed, while repairing works were performed for the existing ones $[133,134]$. In the period of Sultan Süleyman, not only numerous fountains for each district of Istanbul were constructed, but also many waterways were either constructed or repaired in the Medina and Kudus provinces. This indicates how the Ottomans effectively associated the importance of urbanization with water management [133,134]. Most of the water conveyance structures built in Ottoman times are still in use today [135].

Irrigation was actively performed in the Fertile Crescent (Mesopotamia, Egypt, Jordan, etc.) and other adjacent regions during the Ottoman period. Ottomans developed irrigated agriculture in river basins' areas such as Danube, Nile, Euphrates, Tigris, Sakarya, Red, Yeşilırmak, Çoruh, Seyhan and Ceyhan, which are next to the sea in three continents.

One of the important irrigation projects in Anatolia was constructed during the Ottoman period. There were no large water structures except for the Konia Plain Irrigation (Figure 18) in the Ottoman period [136], and the last Sultan, Abdul Hamid (1876-1909), instigated this important irrigation project. The land to be irrigated begins at Konya and extends southeasterly, east, and west of the railway for a distance of $50-60 \mathrm{~km}$, covering an area of some $500 \mathrm{~km}^{2}$. This plain lies from 1000 to $1200 \mathrm{~m}$ above sea level. The rivers Beysehir and Carsamba convey water from Lake Beysehir to the Konia plain (in the present-day Turkey), where it is delivered into a system of secondary canals through three main supply canals, and then into tertiary canals. By cutting the banks of the last canals, farmers delivered water to these parts of their land for irrigation, and afterwards water could flow off into drains. A considerable amount of water was lost by evaporation, and the rest reached the main drains, which discharged onto low-lying grounds to the northeast and east of the plain [137].

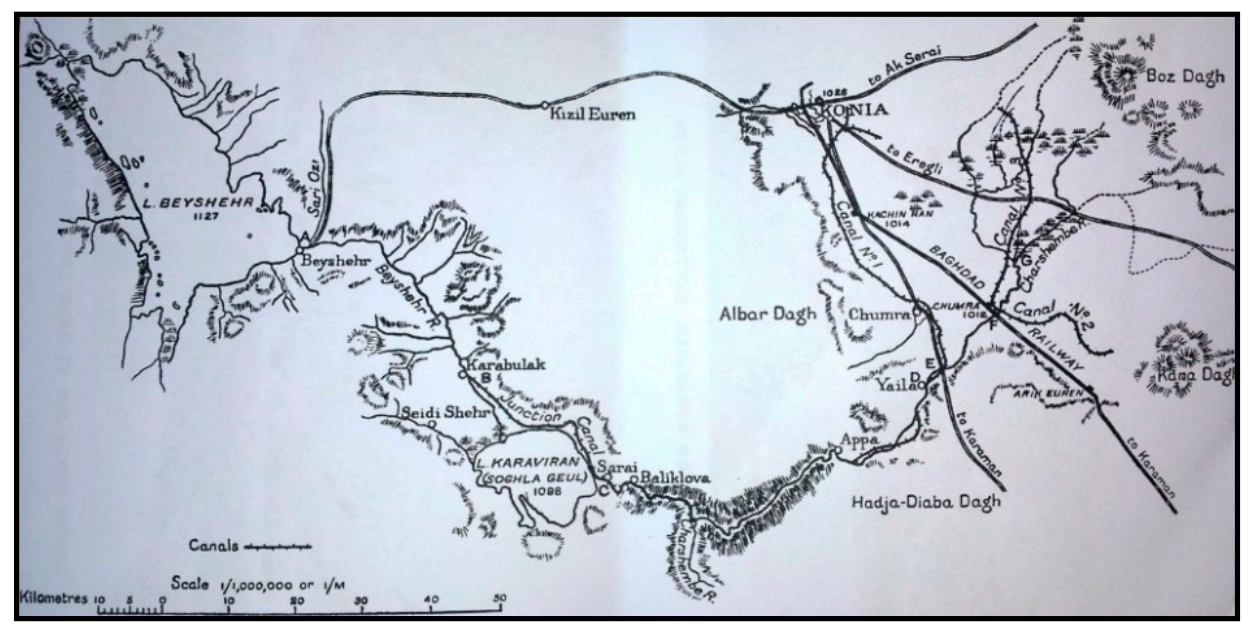

Figure 18. Sketch map illustrating the irrigation network of the Konia Plain (adapted from [137]). 
During the Ottoman domination, irrigation projects developed in some areas of the present day Turkey and Egypt, such as Konya and El-Fayyum. The Fayyum lies in a large natural depression in Egypt's western desert, known as the Libyan Desert [138] (Figure 19), and irrigation provides a particularly good lens through which the history of Ottoman Fayyum becomes visible. Irrigation structures also allow understanding the region's relationship to the rest of the Ottoman Empire, because it was a local process, and differed according to each particular village environment, canal, sluice gate, and embankment. Water had to be managed and controlled by individuals on the ground with in-depth knowledge and experience of the local environments. At the same time, irrigation was a process of wide concern [139].

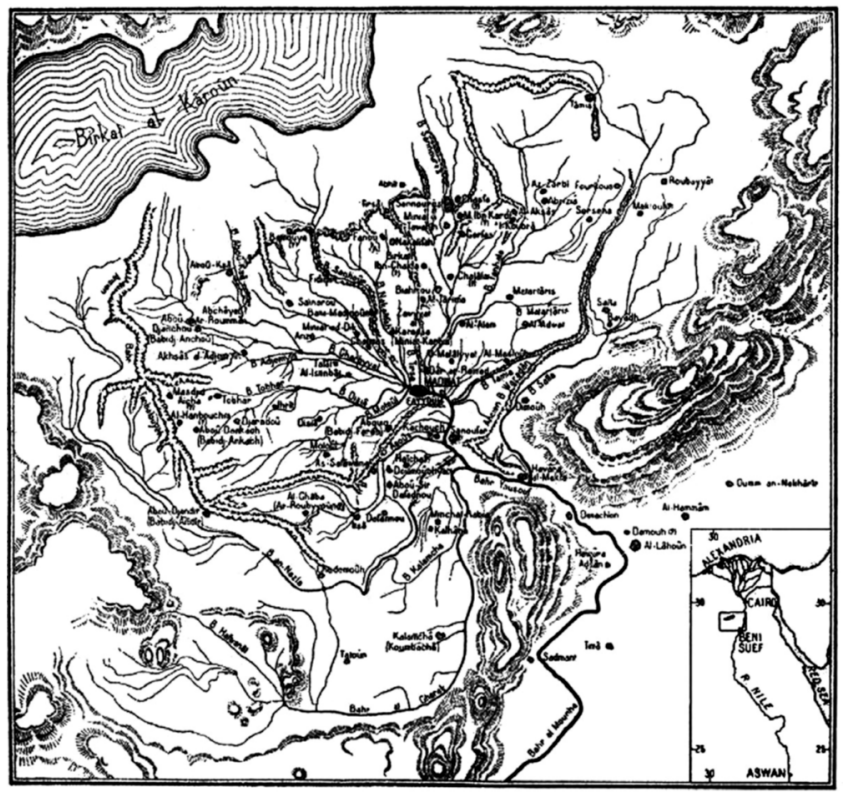

Figure 19. A map of El-Fayyum in Ottoman times (modified from [139]).

El-Fayyum is separated from the Nile Valley to the east by a high ridge of loose stones and soil. The area of El-Fayyum is roughly $1733 \mathrm{~km}^{2}$, with nearly all of it being suitable for farming and crop production (Figure 20). This ridge is pierced at only one point by a natural opening, and through this inlet a canal conveys all of its water (except scant amounts from rain) to El-Fayyum for irrigation and other purposes. This extremely important waterway is known as Bahr Yusuf and branches off from the Nile at Beni Suef. The canal leaves the Nile Valley at an area known as al-Lahun and enters El-Fayyum later, at a point known as al-Hawara. The two most important irrigation features on Bahr Yusuf were the regulating dike of al-Lahun and the seawall-like dam of al-Gharaq $[139,140]$. The dike of al-Lahun was built at the narrow gap that allowed Bahr Yusuf enter into El-Fayyum, and thus was crucial for regulating the canal flow and the amount of water entering the region. The dam of al-Gharaq was located farther along the canal and was much larger in surface area than the dike of al-Lahun. Ottoman information sources from the period describe it as a huge dam of impressive stature that had been in existence since ancient times [139].

Thanks to the new/expanded/improved irrigation systems and use of modern agricultural tools, the variety of crops increased during the 19th century [141]. These systems also improved the socio-economic situation of the country. 


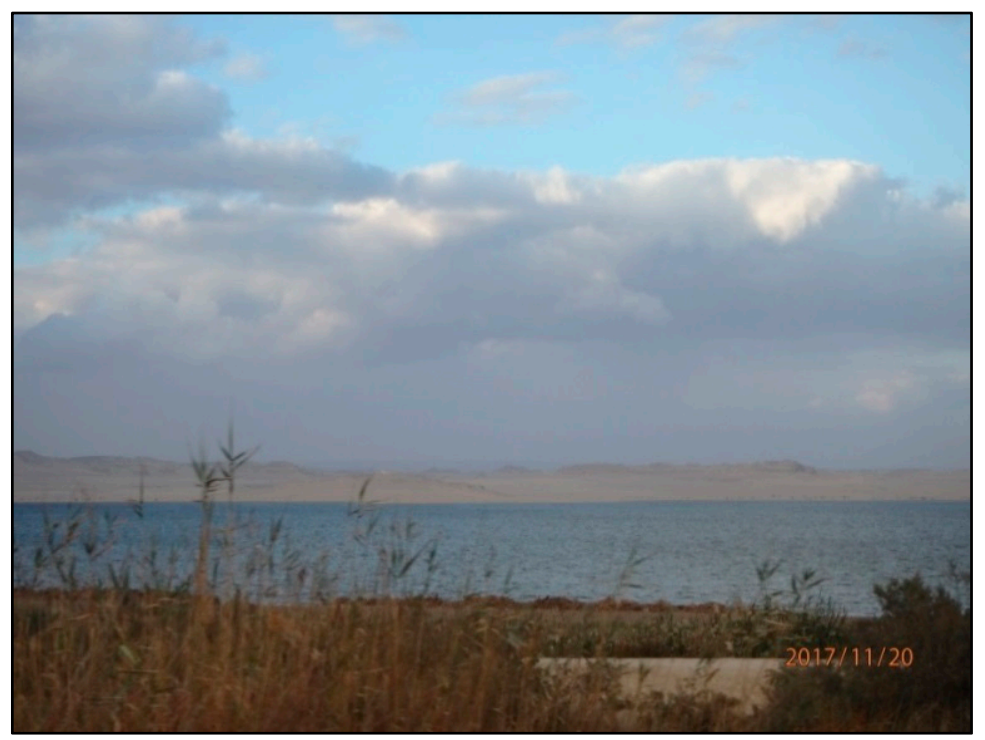

Figure 20. El-Fayyum Lake (photo by M. Salgot).

\subsection{Irrigation Evolution in Present Times (1800 onward)}

Although farmland irrigation has been practiced for millennia to increase and secure food supply for an exponentially growing humanity, a vast expansion in irrigated land mainly took place during the 19th and 20th centuries, with irrigated agriculture becoming the principal water consumer in many countries. Some historians referred to the large development of irrigation in these two centuries as the true catalyst for the interaction of engineering, organizational, political and entrepreneurial skills and activities that contributed to food security and produced increasingly wealthier living conditions [142-144].

In terms of worldwide figures, it was estimated that around 1800 the extent of irrigated land was about 8 million $\mathrm{hm}^{2}$, and it reached 47 million $\mathrm{hm}^{2}$ around 1900. The four countries with the largest irrigated areas in 1900 were India, China, the USA and Pakistan, respectively [145].

During the 20th century the extent of areas equipped for irrigation doubled by 1945 and doubled again by 1980 [146]. The area equipped for irrigation between 1900 and 2000 at global level, in stacked order for the four major irrigation countries is shown in Figures 21 and 22; whereas the information about growth in irrigated areas by decades from 1950 to 1990 is presented in Table 1 as reported by [147].

However, in some regions such as sub-Saharan Africa, irrigation expansion and advances were limited with respect to the available land and water resources. In this region, many irrigation developments were attempted in the past, and several irrigation projects failed because of a combination of high investment costs, poor planning and lack of maintenance. As a result, until very recently, sub-Saharan Africa continues to have untapped water resources and a large potential for irrigation development [148], although there are various constraints to consider [149]. 


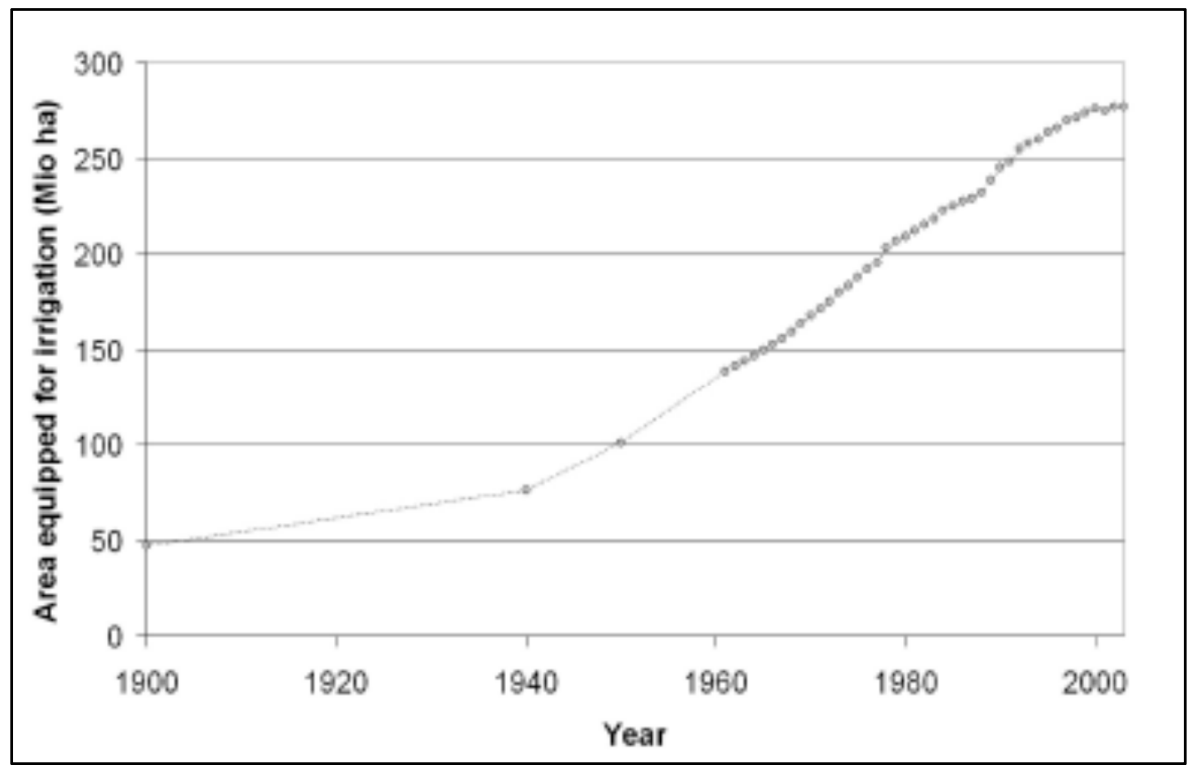

Figure 21. Global extent of the area equipped for irrigation during the period 1900-2000 (adapted from $[146,150])$.

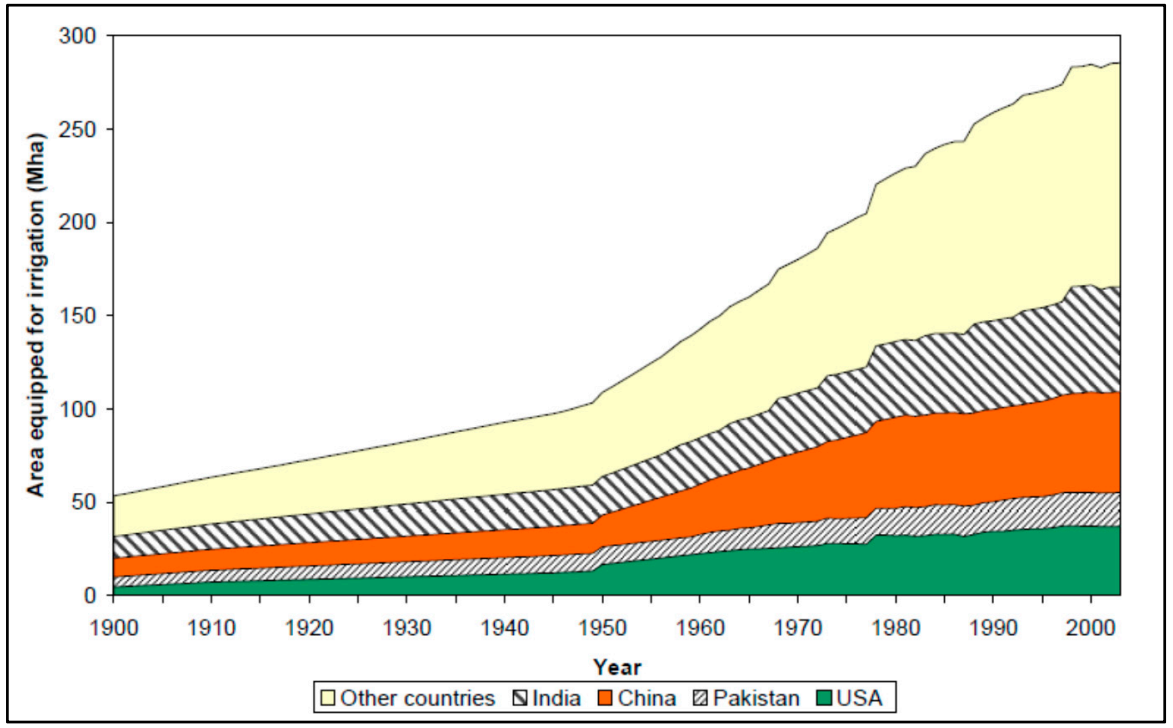

Figure 22. Area equipped for irrigation between 1900-2000 for the four major irrigated countries and the rest of the world (adapted from [145]).

Table 1. Growth in irrigated areas from 1950s to 1990s (adapted from [147]).

\begin{tabular}{|c|c|c|c|}
\hline Decade & Annual Growth (M Ha) & Annual Rate of Growth (\%) & \multicolumn{1}{c|}{$\begin{array}{l}4.5 \% \\
4.0 \%\end{array}$} \\
\hline $1950 \mathrm{~s}$ & 16.5 & $4.30 \%$ & $3.0 \%$ \\
2 & $2.50 \%$ & $2.0 \%$ \\
$1960 \mathrm{~s}$ & 13.3 & $2.50 \%$ & $1.5 \%$ \\
& 16.8 & $1.70 \%$ & $0.5 \%$ \\
\hline $1970 \mathrm{~s}$ & 14.5 & $1.30 \%$ & $0.0 \%$ \\
\hline $1980 \mathrm{~s}$ & 12.6 & & \\
\hline $1990 \mathrm{~s}$ & & & \\
\hline
\end{tabular}


The UN Food and Agriculture Organization (FAO) $[150,151]$ reported that the global area equipped for irrigation worldwide increased from 184 million hm $\mathrm{hm}^{2}$ in 1970 to 258 million hm² in 1990 and finally reached 324 million $\mathrm{hm}^{2}$ in 2012. In the 1980s, the rate of increase in irrigated areas slowed considerably [152,153]. Siebert and Doll [154] attributed this slower expansion of irrigated areas after 1980 to the fact that many large-scale irrigation schemes in Eastern Europe and the former Soviet Union (regions characterized at that time by the transition from central planning economies to market economies) went out of operation because water infrastructures were not sufficiently flexible to meet the requirements of new market-oriented private commercial farming models. In other irrigated areas, the lack of adequate drainage infrastructures caused water-logging and salinity problems that impaired the productivity of irrigation schemes and created urgent needs for costly rehabilitation. At the same time, limited water resources, increasing competition for water by other sectors, and environmental regulations strongly restrained irrigation expansion in many arid areas. For the period after 2000, the World Water Resources Report [146] indicates that in a number of developing and developed countries the extent of irrigated land has stabilized or even diminished due to the very high cost of irrigation networks, salinity-induced problems, depletion of water-supply sources, and rising public concerns on environmental protection.

The rapid irrigation expansion during the 19th and 20th centuries can be related to several factors. Sojka et al. [155] pointed out that, while the main physical relationships related to water flows, i.e., among mass, energy and turbulence, were well investigated and mastered at remarkably high levels of proficiency in the ancient cultures, the understanding of physical and chemical soil-water interactions was somehow inadequate until the beginning of 19th century. In ancient irrigation development, the combination of soils, climate, water quantity and quality knowledge were more established at some locations than others. At some schemes, in fact, irrigation has continued to the present day without skilled or sophisticated management, either because seasonal rains provided sufficient leaching, or because soils were sufficiently permeable and well drained to prevent water-logging and salinity accumulation. In other cases, irrigation water had favorable chemical composition that avoided the occurrence of land-impairing situations. In other areas, increased soil salinity and/or sodicity, as well as raised water tables, have either limited the functionality of irrigation schemes or adversely affected land productivity. The success or failure of irrigation schemes, as well as their productivity and sustainability, became tightly dependent on skilled design and management, as populations grew and the need for increased food supplies encouraged irrigation development on more marginal areas with less productive soils, poorer drainage, and greater natural or induced salinity and sodicity problems. In turn, these aspects required the knowledgeable application and adaptation of scientific principles that started being developed and consolidated from the mid-19th century onwards.

Then, a conjunction of progress and learning in several scientific disciplines, including soil science, hydrogeology, chemistry, physical-chemistry, physics, and plant physiology occurred and contributed to foster irrigation development. These disciplines were adapted, blended and applied in the sub-disciplines of soil chemistry, soil physics, soil biology, crop physiology and agronomy, whose fundamentals proved being essential knowledge for irrigation design, construction and operation, as well as for their economic, social, and environmentally sustainable management.

Similar patterns occurred both in the old and new continents. For instance, from the turn of 19th century onwards, Southern Europe experienced a vigorous upturn and expansion of irrigation, which was mainly fostered by an upcoming industrial economy, high demographic pressure and adapting agriculture, as well as by the availability of affordable energy. Leibundgut and Kohn [156] report that specific new laws for field irrigation and grassland (meadow) cultivation frequently encouraged the modernization of existing and the implementation of new irrigation systems, as well as the foundation of large irrigation cooperatives/associations. In comparison to more traditional irrigation schemes developed in historical periods (e.g., middle ages), the newly developed irrigated areas of 19th and 20th centuries were usually large-scale upstream-controlled systems laid out by engineers. Such systems were characterized by gravity-fed designs, whose implementations required labor- and 
capital-intensive works to reshape and modify valley-floor plains, as opposed to earlier projects largely adapted to natural landscapes and land contours. Official regional statistics and land register records begun to be available from the 19th century onwards, which provide quantitative information about the overall irrigated area [157].

Leibundgut and Kohn [156] indicate that, in terms of spatial extension and geographical distribution, irrigation in Europe probably reached its peak around the turn of the 20th century. Modern irrigation developments were launched in Spain soon after the end of the Civil War in 1939, based on a national water development plan designed by the government prior to the war. Such developments, originally established to settle small farmers, constituted the foundation of a vibrant irrigated agriculture today, which expanded to 3.7 million $\mathrm{hm}^{2}$ and is the largest irrigated area in the European Union.

In the USA, modern irrigation developments are reported to have probably begun with the Mormon settlement of the Utah Great Salt Lake Basin in 1847, followed by the cultivation of nearly 2.5 million irrigated $\mathrm{hm}^{2}$ across the inter-mountain western USA by 1900. America's Mormon pioneers chose to settle in a remote salt-impaired desert habitat, and thus were forced to use trial and error and application of all available new knowledge to reclaim lands from the desert and practice sustainable irrigated crop husbandry, as described by [155]. According to Reisner [158], the Mormon pioneers were very successful in their efforts to the point that the practices they followed in reclaiming, managing, and irrigating arid and salt-affected lands provided the main guiding principles for irrigation developments that occurred throughout the western USA before and under the Reclamation Act since 1902. The passage of the Desert Land Act of 1877 and the Carey Act of 1894 spurred irrigation developments further in the western USA, providing the legal framework to land acquisition for settlement and support of governmental infrastructure for development.

Bucks et al. [145] refer that the lessons learned in the settling of the American West from 1847 onward provided many practical modern principles and methodological approaches of irrigation systems design and operation, and irrigated soil management until the end of World War II, when the total U.S. irrigated area had grown to 7.5 million $\mathrm{hm}^{2}$. Concurrently, the innovations and designs, developed in this context, had worldwide importance. Irrigated agriculture remained an engine of the western U.S. development until the 1970s [159].

After World War II, another wave of rapid irrigation expansion occurred worldwide, owing to a fast population growth and to the increasing demand for safe food supplies. For the largest part, this population expansion resulted from the progresses obtained in public health and the successful control of malaria and other insect-borne diseases in many regions, which in turn significantly increased life expectancies. In addition, the first and the second World Wars spurred advances in technology that were applied to many production areas, including agriculture. Among those, electrical, steam and internal combustion power sources became available to lift and pressurize water. New pump designs and the patenting of sprinkler delivery systems came together in a few decades between and immediately following the wars and revolutionized the ability to withdraw, convey and deliver water. Before it, with the invention of internal combustion engines and shallow well pumps, irrigation largely expanded beyond riparian and gravity flow service areas.

Available records show that irrigation gained even more prominence under the Green Revolution of the second half of the 20th century. The Green Revolution was initiated to address the issue of malnutrition in the developing world, and combined plant genetic improvements with agronomy (greater use of fertilizers, pesticides, and irrigation) to increase crop yields. In several parts of the world, the availability and use of irrigation water represented a key factor for the positive results accomplished by the Green Revolution, such as in the Indian sub-continent. The UN-FAO [160] estimated that in 2003 the total world-wide irrigated area was 277 million $\mathrm{hm}^{2}$, corresponding to about $18 \%$ of the total cultivated lands (Table 2), with the largest proportion of this area (70\%) being in Asia, as shown in Figure 23. 
Table 2. Area equipped for irrigation and percentage of cultivated land for selected years (adapted from [160]).

\begin{tabular}{|c|c|c|c|c|c|c|}
\hline Region & \multicolumn{3}{|c|}{ Irrigated Area $\mathbf{( M i l l i o n}_{\mathbf{~} \mathbf{h m}^{\mathbf{2}} \mathbf{\text { }}}$} & \multicolumn{2}{c|}{ Irrigated Area as of Cultivated Land } \\
\hline Year & $\mathbf{1 9 8 0}$ & $\mathbf{1 9 9 0}$ & $\mathbf{2 0 0 3}$ & $\mathbf{1 9 8 0}$ & $\mathbf{1 9 9 0}$ & $\mathbf{2 0 0 3}$ \\
\hline World & 193 & 224.2 & 277.1 & 15.8 & 17.3 & 17.9 \\
\hline Africa & 9.5 & 11.2 & 13.4 & 5.1 & 5.7 & 5.9 \\
\hline Asia & 132.4 & 155 & 193.9 & 28.9 & 30.5 & 34 \\
\hline Latin America & 12.7 & 15.5 & 17.3 & 9.4 & 10.9 & 11.1 \\
\hline Caribbean & 1.1 & 1.3 & 1.3 & 16.4 & 17.9 & 18.2 \\
\hline North America & 21.2 & 21.6 & 23.2 & 8.6 & 8.8 & 9.9 \\
\hline Oceania & 1.7 & 2.1 & 2.8 & 3.4 & 4 & 5.4 \\
\hline Europe & 14.5 & 17.4 & 25.2 & 10.3 & 12.6 & 8.4 \\
\hline
\end{tabular}

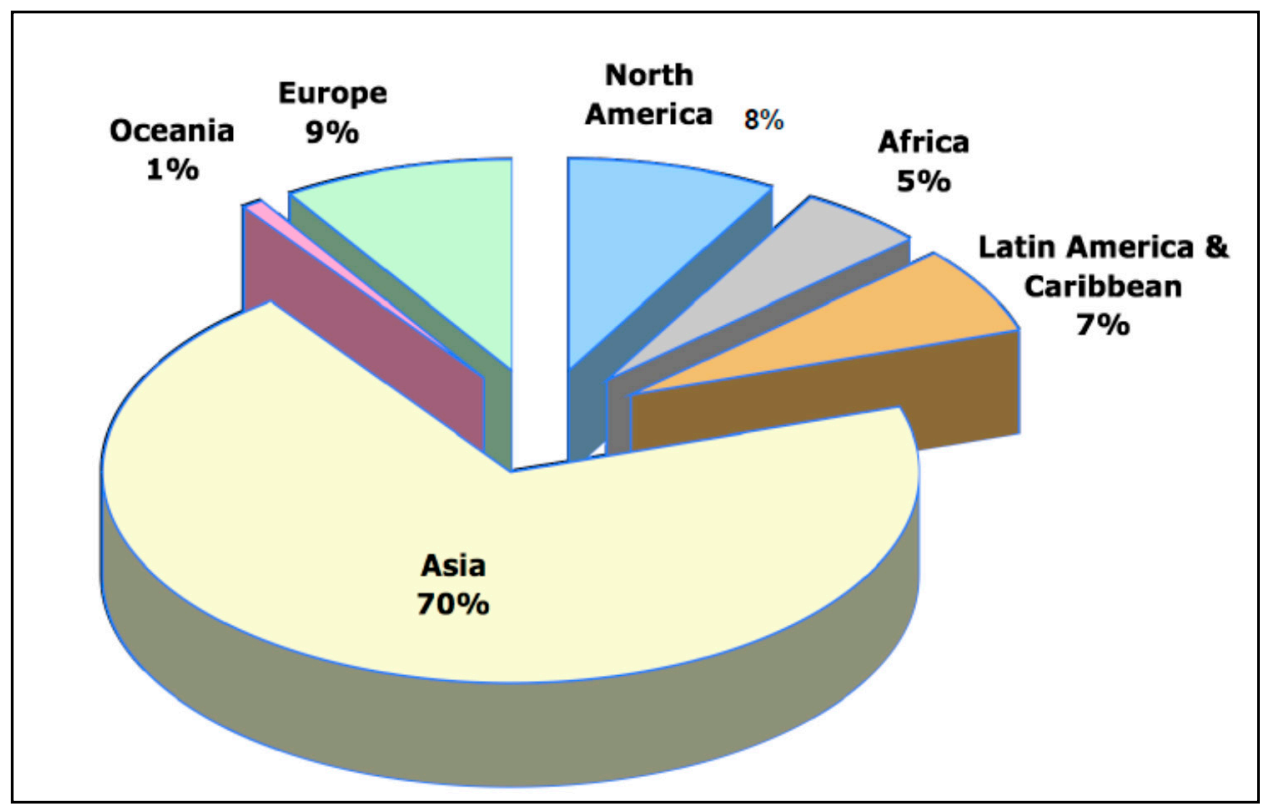

Figure 23. Distribution of irrigated surface in the World by major geographic regions (adapted from [160]).

The introduction of advanced western hydraulic engineering technologies in China and other Asian countries between the end of the 19th century and the beginning of the 21st century gradually encouraged the reconstruction and expansion of traditional irrigation districts and the construction of modern irrigation projects. A group of intellectuals appeared that had been exposed to both western education and oriental cultural influence, who became the promoters of hydraulic reforms during this period. Among all these practices, eight irrigation canals in the Central Shaanxi Plain, including Jinghui and Luohui canal and others, were built by Li Yizhi, who was the major representative of these promoters. Since the founding of the People's Republic of China in 1949, irrigation in China has been developing in full scale, improving significantly the ability to resist drought and flood disasters in agriculture.

From the 1970s onwards, increasing development costs, reducing governmental support and financing, rising demand for municipal and industrial water supplies, diminishing sources of fresh water supply, and a growing concern for the environment have forced water managers and planners to begin rethinking traditional approaches to agricultural water management [161]. Most of projects developed around the world during the 1980s were fueled by financial resources from national or international agencies and were largely expected to result in national self-sufficiency in producing staple foods. As a result, these irrigation schemes tended to be centrally organized and operated by state authorities (government-based irrigation systems), which often also directed input supply 
and cropping patterns. Several of these projects failed to meet expectations, as farmers had very little opportunities to get involved in management and decision-making, and felt no incentive and commitment to proper water use, system maintenance, forced crop selection, and high-productivity. A second generation of agency-funded projects encouraged farmers assuming a sense or responsible ownership of irrigation schemes as major key for success. This objective was pursued through the self-organization of water users, who could understand the economic potential of farmer-managed irrigation systems and thus assume full responsibility. Funding agencies therefore fueled irrigation expansion through development of farmers-managed irrigation schemes and through irrigation management transfer (IMT) programs, i.e., transferring responsibility, decision-making and financing of irrigation systems from public sector to water users' organizations. In this context, one of the main funding agencies' goal was to ensure that irrigation systems would provide adequate, flexible and more dynamic water delivery services to meet the needs of market-oriented agriculture.

\section{Main Agricultural Water Management Challenges and Future Trends}

\subsection{Present Day Challenges in Irrigated Agriculture}

Irrigation has been playing a crucial role in the economic development of many countries that extends far beyond the production of food and fiber. In several areas of the world, it made the settlement and establishment of active communities possible, while transforming lands with little or no apparent economic value into highly productive and market-oriented farming systems. An often-overlooked key benefit of irrigation, yet not easy to quantify, is food security, i.e., the security derived from stability of food production. Weather vagaries and seasonal rainfall fluctuations could make rain-fed farming a risky venture, whereas irrigation reduces some of the uncertainties and promotes increased and stable crop production [121]. According to the Second United Nations World Water Development Report [162], there is a strong positive link between investments in irrigation, poverty alleviation and food security. Irrigation allows minimizing abrupt and unpredictable yield reductions that many world's food production areas would face due to recurring or sporadic droughts.

Presently, more than $60 \%$ of the cereal production worldwide and $50 \%$ of the value of all crops harvested come from irrigated agriculture. Irrigated land produces on average two to two and half times the yield and three times the crop value per hectare relative to non-irrigated farmland, with the irrigation portion amounting to only one sixth of the world's total production area, including cropland, rangeland, and pasture [145,150,163-165]. However, the success of irrigation projects has been often achieved through strong governmental involvement and support (both in terms of engineering and financial assistance), and has been fueled by economics and market patterns. In the last two decades, government involvement and support for irrigation development have greatly diminished, and the role of agriculture has changed in the economy of many developed countries, with some of the nations' priorities shifted towards increased environmental concerns and the need to compete in the global economy.

The world community has become aware that irrigation causes serious land transformations, that are often permanent and irreversible and take place mainly in two ways: (a) by direct modifications of the land surface, occurring when water conveyance and distribution networks are constructed, and lands are cleared, shaped and leveled for farming and irrigation; and (b) by in-depth transformations taking place when the water and salt balances in the region are changed as a consequence of importing large quantities of water and salts into the area [121]. As such, it is now recognized that irrigation development is a dynamic process disturbing the natural water and salt balance of a region, and eventually causing irreversible damages to the local ecosystems, from the projects' onset to the medium and long term. Among the major adverse ecological effects, the diversion and storage of water for irrigation profoundly alter the natural hydrology of streams and the habitats of native plants and animals depending on them. Moreover, the application of large quantities of water to irrigated lands may result in soil erosion and sedimentation of streambeds. At the same time, salts, organic matter, 
solids of several sizes, fertilizers and pesticides may be leached out from the soil and transported into rivers, streams or aquifers, alongside with microorganisms and several pathogens.

Several surveys have indicated that of the existing irrigated lands, some 40-50 million hm² show measurable degradation from water logging, salinization, and sodification (e.g., [166,167]) leading often to desertification. All these adverse environmental and ecological consequences of irrigation, i.e., water diversion and consumption, impacts on water quality, effects on aquatic ecosystems, are increasingly being scrutinized and questioned [161], and there are calls for intensified research and wide adoption of conservation and resource-efficient water management practices. The challenge of soil losses due to combinations of these negative factors must also be addressed.

Irrigation developments have also several extended positive impacts, including social and economic benefits such as flood control, transportation and recreation, as well as hydropower, creation of employment opportunities and rural development. At the same time there are positive ecological effects resulting from transformation of drylands into green areas that produce large amounts of oxygen and fix carbon dioxide and accommodate through fields, ditches, canals and reservoirs, the habitats where a wide range of wildlife thrive, as opposed to deserts and undeveloped natural arid lands. Nevertheless, part of the mentioned impacts can be considered negative from the ecological point of view, since they alter or even destroy natural ecosystems (arid and semiarid).

Sojka et al. [155] highlighted that irrigated agriculture has greatly enhanced its ability to provide humanity's essential needs in closer harmony with environmental balances. There are opposite opinions indicating that the natural characteristics of deserts are being lost through irrigation, including specific flora and fauna. The case of the Segarra-Garrigues canal in Lleida province, Spain is paradigmatic, with the EU having forced to reduce the irrigable area in order to protect and conserve steppes' birds [168].

According to data from major international agencies, population growth is occurring mostly in developing countries, where there are added expectations of improved diet and standards of living that raise the need for increased food production per capita above a simple linear extrapolation based on population projections [155]. In fact, only intensive and high-yielding crop production from irrigated agriculture has the potential to achieve these projected performance targets. At the same time, the production of biofuels represents an additional demand on water resources, and also competes with food for limited water and land [169].

Besides meeting the increasing needs for food and energy (biofuels), the main challenge faced by irrigation planners is no longer the high agricultural productivity only, but rather the long-term economic and environmental sustainability of irrigated areas. The potential hazards intrinsic to irrigation developments need to be carefully evaluated at the planning stage, and minimized during the operation phase, if the stability and permanency of irrigation projects are to be ensured. Several authors $[166,170,171]$ report that the adequate knowledge and technology exist to design, implement and operate irrigated cropping systems in an environmentally compatible way, and thus prevent progressive and sometimes irreversible land and water resources impairments. However, in most cases, when designing and developing a large-scale irrigation project there is a great political emphasis and pressure to develop as many irrigated hectares as possible at the project outset. As a result, often not sufficient financial and technical resources are allocated to implement known scientific principles and technologies in a timely manner, as part of irrigation systems design and management. Also, in many projects there is not sufficient provision of technical and social support to assist the farming community with the transition from rain-fed or no agriculture to irrigated agriculture. Often, this insufficient assistance is perceived at later stages as failures of irrigation, but in reality, those are failures in the human institutions and project governance, as pointed out by Sojka et al. [155]. In this regard, a real challenge for irrigation expansion in the near future is reaching consensus around social, political, economic and institutional considerations rather than only promoting technical advances on water availability and use.

Overall, the availability of suitable land and water is likely to remain the principal determinant of the extent of irrigation and its expansion at the global scale. Water-related costs are rising and demands 
on the available water resources are growing rapidly in many areas of the world, generating increasing competition for fresh water supplies, and both trends are very likely to continue in the future. Irrigated agriculture is currently, and will most likely in the future, be particularly subject and vulnerable to water supply fluctuations. Alongside, irrigation methods, systems and management practices will continue evolving towards advanced technologies to provide better water control, communication and record-keeping, improve water and nutrient management, enhance soil and water resource use efficiency, and minimize their degradation.

All the above-indicated factors call for inevitable changes in how water is managed, allocated and valued in the future. Among others, the major key change drivers are population growth, urban expansion and resulting loss of agricultural acreage, increasing competition over fresh water supplies, changing of policy objectives, and increasing environmental concerns. The possible response to those drivers may be developments in science and technology and changes in management practices, as well as governance, institution, and policy reforms.

In terms of science and technology, in the last decade efforts have shifted away from construction of large irrigation infrastructures, such as dams, reservoirs, and large-scale water supply and delivery systems (Figure 24), and more attention is being given to improve on-farm irrigation systems and management practices to reduce the total amount of water diverted from various sources. There is a clear trend, fostered by financial incentives and technical support programs, towards broader adoption of micro-irrigation methods that apply water at slow rate in the vicinity of plant roots, thus enabling improved water and nutrient crop management and efficiencies. Research institutions are also working to breed and test new plant varieties that are drought tolerant, drought resilient, or better adapted to water stress. However, substantial water savings from irrigation technologies and genetic engineering do not appear imminent, although large efforts are being made to develop durable techniques and strategies. In terms of irrigation technology, it is tempting, and has been so for decades, to address the need for better on-farm irrigation efficiency only with technological interventions rather than by application of better management techniques [172].

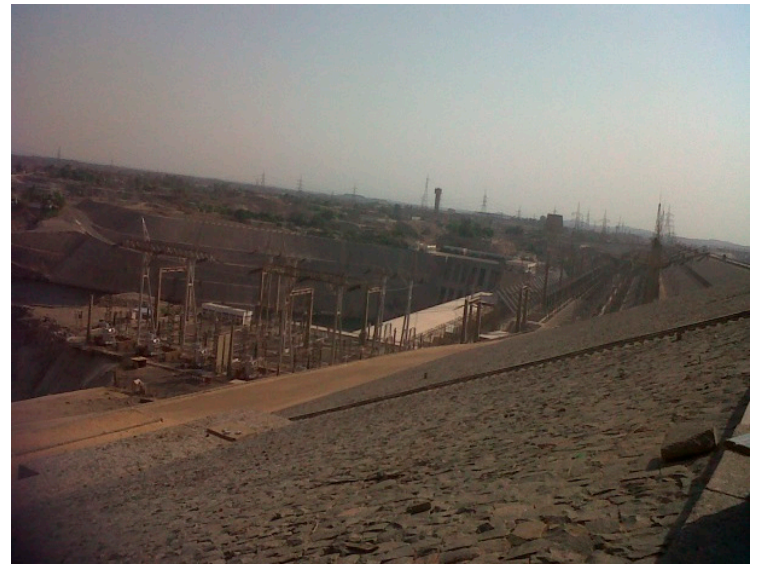

(a)

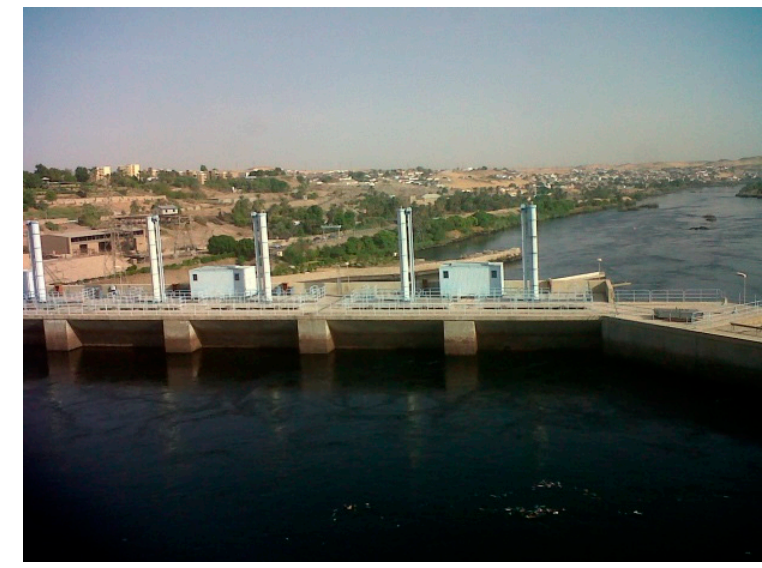

(b)

Figure 24. Aswan dam in Egypt: (a) view of today; and (b) past view (Photos by M. Salgot).

Innovative irrigation technology is generally promoted as enhanced water-use efficiency along with multiple other benefits, but often these remain elusive in practice. In many cases, individual farmers and/or their organizations made significant investments in irrigation technologies, but their implementation has not been systematically evaluated for effectiveness through better knowledge regarding soil-water-plant relationships. As a result, frequent investments in technological improvements have been causing higher water prices without gaining the full potential benefits due to increased water efficiency, as indicated by Levidow et al. [173]. Under such circumstances, irrigated agriculture will likely maintain relatively low water-efficiency levels, and farmers will have 
no clear incentives to improve, and most likely will make no efforts towards implementing more efficient practices. Reversing these tendencies will require continuous knowledge-exchange and knowledge-delivery programs, and that all relevant stakeholders share greater responsibility and benefits for increasing the efficiency across the entire water-supply chain. From this perspective, it will be crucial that more water-efficient management practices could also demonstrate how to combine wider environmental benefits with economic gains for farmers, without forgetting the possible negative impacts of new practices, i.e., pursuing eco-efficient water management practices.

From an institutional perspective, development agencies and local governments have also shifted the focus from policies for developing new irrigation schemes to better management and modernization of existing schemes, and towards increased environmental protection, while strongly reducing subsidies. In some cases, water-management agencies are also developing policies to implement water transfer programs among different water-use sectors.

\subsection{Future Directions Anticipated in Irrigated Agriculture}

With this historical review and modern perspective of current pressures and drivers on irrigated agriculture, we offer a few likely directions anticipated for the future.

Irrigation will continue playing a crucial role in the production of safe food and of biofuel supplies, most likely through agriculture intensification. The total irrigated area will likely remain similar or even decline, but the production from irrigated agriculture will remain constant or slightly increase, thanks to conversion of significant acreage to higher-value crops. In this context, the attention will be mainly given to irrigation performance and the economic efficiency of water use, i.e., water productivity.

Increasing pressure on fresh water supplies from different sectors will put agricultural water use under greater scrutiny and lead to possible decline of water allocations to irrigated agriculture, with increasing fractions transferred to municipal, recreational and environmental uses, as well as to natural landscapes. This will be particularly so in areas under water scarcity and during drought periods. Higher water tariffs, tiered pricing schemes, and water markets will likely be implemented to encourage more efficient agricultural water usage.

The irrigation sector will most likely be expected to comply with higher standards of efficiency as a condition of use, to be monitored through third-party auditing and certification processes. Tiered water pricing, new regulations and some sort of incentives to growers will have to be implemented to achieve higher irrigation efficiency, and support voluntary water transfer programs. This will also encourage research on the use of drought-tolerant varieties and on reuse of water from return flows.

Competition in the global economy, in conjunction with reduced protection to farming activities, will lead growers to deal with more risks and uncertainties. Among those, market conjunctures, fluctuations of crop prices, weather-related changes, and the cost of water and energy supplies, will all make farmers more vulnerable to vagaries and uncertainties. Minimizing some of these risks will entail relocating the production of high-value crops to areas with more dependable water supplies. Successful farmers will adapt to increased uncertainties through innovations in technology, resource-efficient practices, and cropping systems that are more resilient to climate variability and weather extremes.

In several large-scale irrigated areas, there will be a shift towards large-sized well-financed, diversified, and technology-oriented farming operations, run mostly by corporations. Smaller under-financed farms will tend to decline, due to less-skilled personnel and higher vulnerability to risks. Medium-sized farms will instead face hard challenges to stay competitive in the increasingly global economic context.

The increasing pressure for greater efficiency of water use will require research efforts for development and transfer of new technologies and water management practices, from both the public and private sectors (irrigation industry). Irrigation districts and water users' organizations will also have to engage more in testing and demonstrating the cost-effectiveness of new technologies, as well as in supporting education of irrigators to the correct deployment and best use of such innovations. 
In the future, the major issue in the water supply will be related to the long-term availability and sustainability of existing and new water supply sources. Factors that will impact public water supplies are population growth, population demographics, limited availability of new natural sources of water, distribution of existing fresh water sources, increased contamination of these water sources with trace organics and nanoparticles, ageing infrastructures, and climate change [174]. In the next 30 years it is estimated that the world's population will increase from 7.3 billion today to 9.7 billion by 2050 . Also by 2030 , roughly $60 \%$ of the world's population will be living in urban areas. At the same time, it is anticipated that by 2030 , a fraction of that $60 \%$ of the world's population will live near coastal regions, creating even more urban sprawl than already exists [175]. Based on the facts that the available fresh water globally will remain the same, combined with unequal distribution of the world's water resources in many parts of the world, large cities are already water stressed making it necessary to look for non-conventional water resources, e.g., treated wastewater, brackish water and desalinated waters $[176,177]$. In this context, wastewater reclamation and reuse is becoming increasingly necessary to reach equilibrium between supply and demand [178].

\section{Epilogue}

Throughout this review, our contributions clearly demonstrate that water and its proper management has always been a key element for food security. In addition, because of this need, the development of technologies and methodologies to use water efficiently has always been a concern, probably more linked to "sustainable" goals in the past, when nature was considered as part of the environment, than in the current time that are more dominated by economic interests. Nevertheless, an increasing awareness to maintain the planet's natural features is counteracting the economic objectives and then influencing irrigation patterns. A brief timeline of historical developments of agricultural irrigation globally is presented in Table 3 .

Table 3. A Brief timeline for historical development of agricultural irrigation.

\begin{tabular}{|c|c|c|}
\hline Period (ca) & Achievements & Comments \\
\hline $5000-2500 \mathrm{BC}$ & $\begin{array}{l}\text { The first confirmed evidence of } \\
\text { habitation and the first farmers. The } \\
\text { first successful effort in developing } \\
\text { agricultural irrigation. }\end{array}$ & In Mesopotamia \\
\hline $5000-2200 \mathrm{BC}$ & $\begin{array}{l}\text { Emergence of the primitive irrigation } \\
\text { and drainage engineering, and } \\
\text { emergence of wells for irrigation. }\end{array}$ & In ancient China \\
\hline ca. $3100 \mathrm{BC}$ & $\begin{array}{l}\text { Egyptians practiced basin irrigation } \\
\text { using the loading of the Nile to } \\
\text { inundate land plots, which had been } \\
\text { surrounded by dykes. }\end{array}$ & In ancient Egypt \\
\hline 3050-2050 BC & $\begin{array}{c}\text { Early irrigation systems in Egypt and } \\
\text { Mesopotamia }\end{array}$ & \\
\hline $3000-1600 \mathrm{BC}$ & $\begin{array}{l}\text { Ancient Nubians developed a form of } \\
\text { irrigation by using waterwheel-like } \\
\text { device called sakia. }\end{array}$ & In ancient Sudan \\
\hline $2500-1450$ BC & $\begin{array}{l}\text { Irrigated and drainage agricultural } \\
\text { lands in the eastern Crete. Major } \\
\text { irrigated crops were olives and grapes }\end{array}$ & $\begin{array}{c}\text { Minoan settlements (e.g., } \\
\text { Choiromandres, Zakros, Agia } \\
\text { Triada, Messara valley) }\end{array}$ \\
\hline 2500-1900 BC & Irrigation of agricultural lands. & $\begin{array}{l}\text { In Mohenjo-daro and other centers } \\
\text { located in modern Pakistan. }\end{array}$ \\
\hline 2200-771 BC & Emergence of farmland canal systems. & In ancient China \\
\hline $2000-1000$ BC & $\begin{array}{l}\text { Cultures and civilizations in the Niger } \\
\text { river region practiced irrigation based } \\
\text { on wet season flooding and water } \\
\text { harvesting in the first or second } \\
\text { millennium BC. }\end{array}$ & In sub-Saharan Africa \\
\hline
\end{tabular}


Table 3. Cont.

\begin{tabular}{|c|c|c|}
\hline Period (ca) & Achievements & Comments \\
\hline $1500-800 \mathrm{BC}$ & $\begin{array}{l}\text { The realization of the importance of } \\
\text { irrigation is evident already from the } \\
\text { myths of ancient cultures. Irrigation of } \\
\text { Kopais valley in the central Greece. }\end{array}$ & $\begin{array}{c}\text { In various Mycenaean cities (in } \\
\text { south Greece) }\end{array}$ \\
\hline $800-500$ BC & $\begin{array}{l}\text { Development of irrigation and drainage } \\
\text { technology for field cultivation and } \\
\text { gardening. }\end{array}$ & $\begin{array}{c}\text { Mainland Greece, Western Greece } \\
\text { and islands in the Aegean Sea }\end{array}$ \\
\hline ca. $800 \mathrm{BC}$ & $\begin{array}{l}\text { The Qanat technology was developed } \\
\text { which is among the oldest known } \\
\text { irrigation methods and still use today in } \\
\text { several parts of the world. }\end{array}$ & In Persia and other places \\
\hline ca. $300 \mathrm{BC}$ & $\begin{array}{l}\text { The irrigation works in the reign of King } \\
\text { Pandukabhaya and which were under } \\
\text { continuous development for the } \\
\text { following thousand years, were one of } \\
\text { the most complex irrigation systems of } \\
\text { the ancient world. }\end{array}$ & In ancient Sri Lanka \\
\hline $256 \mathrm{BC}$ & $\begin{array}{l}\text { In the Szechwan region, belonging to } \\
\text { the State of Qin, the Dujiangyan } \\
\text { irrigation system was built to irrigate an } \\
\text { enormous area of farmland that still } \\
\text { supplies the water. }\end{array}$ & In ancient China \\
\hline 246 BC & $\begin{array}{l}\text { In the central Shaanxi Plain belonging to } \\
\text { the State of Qin, the Zhengguo Canal } \\
\text { irrigation system was built to irrigate an } \\
\text { enormous area of farmland that today } \\
\text { still supplies the water. }\end{array}$ & In ancient China \\
\hline $167 \mathrm{BC}-330 \mathrm{AD}$ & $\begin{array}{l}\text { Romans invented the Roman concrete } \\
\text { (opus caementitium) which allowed the } \\
\text { construction of long canals, very large } \\
\text { bridges and long tunnels in soft rock. }\end{array}$ & In Roman period \\
\hline 581-1279 AD & $\begin{array}{l}\text { The pond-canal polder system in the } \\
\text { Taihu Lake basin and projects for } \\
\text { resisting seawater intrusion and storing } \\
\text { freshwater in the southeast coast } \\
\text { became the most representative water } \\
\text { conservancy of this period. }\end{array}$ & In ancient China \\
\hline 1200-1500 AD & $\begin{array}{l}\text { Use of Chinampas which is a crop } \\
\text { growing method used by the Aztec } \\
\text { civilization consisting of small } \\
\text { manmade islands placed on lakes in } \\
\text { marshes with no need for irrigation and } \\
\text { optimizing the use of agricultural land, } \\
\text { water and waste to raise yields }\end{array}$ & In Mexico \\
\hline 1279-1911 AD & $\begin{array}{l}\text { The polders in the Poyang Lake and } \\
\text { Dongting Lake of the Yangtze river } \\
\text { basin and dike enclosure at the Pearl } \\
\text { river Delta both entered the large-scale } \\
\text { development period, that made the } \\
\text { Yangtze river basin and the Pearl river } \\
\text { basin become economic centers } \\
\text { of China. }\end{array}$ & In ancient China \\
\hline
\end{tabular}


Table 3. Cont.

\begin{tabular}{|c|c|c|}
\hline Period (ca) & Achievements & Comments \\
\hline \multirow{3}{*}{ 1299-1923 AD } & $\begin{array}{c}\text { Most of the water transmission lines } \\
\text { built in Ottoman times. Irrigation } \\
\text { activity was densely performed in } \\
\text { Fertile Crescent region (Mesopotamia, } \\
\text { Egypt, Jordan etc.) during } \\
\text { Ottoman period }\end{array}$ & $\begin{array}{c}\text { In Anatolia and neighboring } \\
\text { regions }\end{array}$ \\
& It was estimated that around 1800 the \\
& extent of irrigated land was about 8 M \\
ha, and it reached 47 M ha million hm2 & \\
& around 1900 with water consumption \\
& for irrigation 500 billion m3 per year. \\
& The top four countries with the largest \\
& area equipped for irrigation in 1900 \\
& were India, China, Pakistan and USA. & \\
Total water demand is expected to & In the entire World \\
& increase from 4000 today to 5500 billion & \\
& m3/year in 2050 with irrigation to be the \\
& major use. & \\
\end{tabular}

Irrigation has been implemented in Egypt and Mesopotamia since at least 5000 BC, where water of the flooding from Nile, Tigris, and Euphrates rivers was diverted to the agricultural fields for a couple of months during summer and fall. The excess water was then drained back into the rivers before the start of the crop growing cycle.

Chinese irrigation has a long history and a sustainable development. The origin of Chinese irrigation is very early, e.g., well water for irrigation emerged ca 6000 years ago; well-field irrigation system built in the Xia, Shang and Zhou dynasties, and large irrigation projects such as Dujiangy weir and Zhengguo Canal appeared 2000 years ago. Hereafter, due to long lasting and relative "isolation" from other civilizations, Chinese irrigation has always been developing according to its own rules, with its technologies continuously improving.

Secondly, China is vast in territory with diverse natural conditions, (such as topography and precipitation) and requirements of social and economic development, which vary enormously in different regions. These differences resulted in the development of a large number of irrigation projects, which featured various styles.

Thirdly, there is a close relationship between the development of Chinese irrigation and the shift of Chinese economic centers inside the country. The first economic center of China emerged in the lower reaches of the Yellow River, where irrigation was more advanced. With the spread of irrigation technologies, the Yangtze River basin became the economic center, followed then by the Pearl River basin. Even more, the development of these economic centers effectively facilitated the development of local irrigation. Historically, China lead to unique irrigation systems, which made Chinese irrigation become an indispensable and irreplaceable part of world's irrigation projects heritage.

On the contrary to most ancient civilizations, which developed and flourished near rivers and lakes where water supply for drinking and agricultural use was readily available, the Greeks established communities in arid and semi-arid regions since the early times [35]. Thus, the Greeks developed sophisticate irrigation practices and general water management practices due to the water scarcity during the Minoan Era and onwards. Ancient Greek water management techniques displayed a variety of strategies, concerns and, in some instances, ingenuity at a level which inspires to re-contemplate its potential in other contexts. Most obviously, Greek gardening displayed a concern with the multifarious engagement of irrigation, manure, manpower and intensive cultivation of confined spaces. It is borne out of the evidence that the combination of manuring and labor-intensive cultivation with irrigation induced by control and storage of seasonal rainfall can provide a highly effective concept for intensive gardening. 
Less relevant may be the large-scale irrigation projects of the Classical and Hellenistic periods ( $c a$ 500-100 BC), which both had the effect of re-molding the landscape, changing it from rugged, marginal lands into fertile soils of the plains, and providing abundant water to regular field and tree crops cultivation. The few extant examples of large-scale irrigation projects to survive in the material record suggest that irrigation strategies undoubtedly helped addressing highly complex local conditions and problems. Again, however, it may be relevant to contemplate scenarios where erratic seasonal changes of rainfall in semi-dry regions compelled farmers to both control and store rainfall in order to implement larger combined drainage and irrigation strategies.

Terrace irrigation is documented in pre-Columbian America, early Syria, India, and China, as well as in the Mediterranean Basin. In the Zana Valley of the Andes mountains in Perú, archaeologists found remains of three irrigation canals that were radiocarbon-dated from ca. the 4th millennium BC, the 3rd millennium BC and the 9th century AD, respectively [179]. These canals are the earliest records of irrigation in the New World; traces of a canal possibly dating from the fifth millennium $B C$ were found under that fourth millennium canal [180]. Sophisticated irrigation and storage systems were developed by the Indus Valley civilization in present-day Pakistan and North India [181]. In those places, large-scale agriculture was practiced and an extensive network of canals was used for irrigation purposes.

The Aztec culture, although not as ancient as some of the other cultures mentioned, showed a full understanding of the benefits of managing water jointly with land and biodiversity. Certainly, this was because the Aztecs had to face the lack of arable land combined with the presence of water resources that were partly saline. Unfortunately, with the arrival of a new culture, i.e., the Spanish, this philosophy on the integrated management of water and other natural resources was almost lost. Nevertheless, it is now being "re-discovered" by some experts for the aim to deal with similar problems that are affecting many other regions of the world.

While the Aztec water management system was almost lost as indicated, other Central and South American cultures maintained traditional ways of farming the land, and indeed the modern Mayan and Andean people continue practices that reverberate the ancient techniques. Ancient Andean irrigation canals continue to be functional in the contemporary world. Indeed, indigenous Andean farmers still use a similar system to allot water to farms throughout the river valleys [117]. Thus, an ancient Andean system that was institutionalized by the Inca and Spanish imperial rule resonates today in the daily lives of modern Andean farmers.

Indigenous Central American farming techniques in particular have important implications for modern farmers living in tropical areas. Many farmers throughout Southern Mexico, Belize, and Guatemala practice traditional farming methods, planting rain-fed milpas, and produce enough food to feed their families and sell part of the crops on the market. These practices are more sustainable, as they seem better suited to the local environmental conditions than modern Western agricultural practices. Many farmers shun the hybrid corn varieties planted by growers in the United States and Canada, for example, preferring local corn varieties that are better adapted to the seasonal rain and the local traditions of implementing irrigation strategies.

Presently, irrigation is being considered as a way to improve standards of living for farmers, which rely more and more on highly technified ways of applying water to the soil-plant system. The water-energy-food nexus is now guiding brand new approaches to make irrigation a sustainable practice from various viewpoints. The most important is perhaps the capacity of ensuring sufficient and healthy food supply for an ever-growing world population, i.e., food security and safety. Water for irrigation is a basic commodity but it is not to forget that, without soils in good productive conditions, agriculture would not thrive even if there is enough water to grow plants for food production.

Finally, the lessons learned from the past and the existing concerns point to several future main water-related challenges and trends, as indicated hereafter:

- $\quad$ water supply will be limited and regulated for all users, with water rights and water pricing schemes to be re-visited and adapted to changing conditions; 
- larger quotas of water will be transferred from agriculture to urban areas, recreational activities and the environment;

- increased climatic variability will exacerbate problems of water supply and expose farmers to increasing vagaries and uncertainties;

- degradation of land and water resources may become more substantial and as well draw increasing public attention;

- more resource-efficient management practices will be needed at farm level that could also combine wider environmental benefits with economic gains for farmers;

- cropping systems implemented in irrigated agriculture in the arid and semiarid areas will need to adapt to less water availability and to lower-quality supplies;

- new varieties and cultivars of plants more adapted to drier conditions are and will be essential for a better use of water in agriculture; and

- the knowledge of the relationships of water and nutrients with the different types of soils will be also essential for proper agricultural water management.

Lessons from the past must not be forgotten, as they will help avoiding a broad range of mistakes perpetrated nearly consistently along the millennia.

Author Contributions: A.N.A. conceived the idea of this review article, contributed to the project idea development, prepared the first draft of the manuscript (writing the original draft, reviewing and editing, collecting and preparing the figures), collected the information for developing the body of text and supervised the research. D.Z. wrote the last three sections (Irrigation in the modern times, Main agricultural water management challenges and future trends, and Epilogue). He also revised and edited the manuscript. J.K. mainly contributed to the Section 3 on Historical Times, but also revised and edited the manuscript. M.S. provided contribution to the Section 6 on Medieval Times and revised the manuscript. M.B. contributed to the Sections 1 and 2 on Prolegomena and Prehistoric Times, respectively. P.R. has contributed to the Section 3 on Historical Times. B.J. elaborated the Section 3 on Late Pre-Columbia Civilizations. A.K. provided contribution to Section 2 on Prehistoric Times. W.Y. has mainly contributed to the narrative about irrigation in China. A.B. contributed to the Section 2 on Prehistoric Times. J.A.H. provided contributions to Section 2.4 on the Maya Civilization. A.G.-J. has mainly contributed to the Section 3 on Late Pre-Columbia Civilizations. E.F. has revised and edited the manuscript, providing contributions to various sections. All authors have read and agreed to the published version of the manuscript.

Funding: This research received no external funding.

Acknowledgments: We greatly acknowledge Raffaella Sibilla, Renata Teixeira de Almeida Minhoni and Giuseppe Inchingolo, all collaborators in the Agricultural Water Management Lab of the LAWR Department of UC Davis, for their valuable contributions in editing and reviewing multiple sections of the manuscripts. The authors are also very grateful to Prof. Mark Grismer from the LAWR and BAE Departments of UC Davis for conducting a detailed review of the final version of the manuscript.

Conflicts of Interest: The authors declare no conflict of interest.

\section{References}

1. Breasted, J.H. Ancient Times: A History of the Early World; The Athenaeum Press: Boston, MA, USA, 1916.

2. Koutsoyiannis, D.; Angelakis, A.N. Agricultural Hydraulic Works in Ancient Hellas. In The Encyclopaedia of Water Science; Stewart, B.A., Howell, T., Eds.; Markel Dekker Inc.: New York, NY, USA, 2004; pp. 1-4.

3. Sallares, R. The Ecology of the Ancient Greek World; Cornell University Press: New York, NY, USA, 1991.

4. Lebesi, A. The Miniature House from Archanes; Archaiologiki Ephemeris: Athens, Greece, 1965; pp. $12-43$.

5. Angelakis, A.N.; De Feo, G.; Laureano, P.; Zourou, A. Minoan and Etruscan hydro-technologies. Water 2013, 5, 972-987. [CrossRef]

6. Luthin, J.N. Drainage of Agricultural Lands; American Society of Agronomy: Madison, WI, USA, 1957.

7. Krasilnikoff, J.A. Irrigation as innovation in ancient Greek agriculture. World Archaeol. 2010, 42, $108-121$. [CrossRef]

8. Bazza, M. Experience on Wastewater Reuse in the Near East; FAO Regional Office for the Near East: Cairo, Egypt, 2003.

9. Bazza, M. Overview of the history of water resources and irrigation management in the Near East region. Water Sci. Technol. 2007, 7, 201-209. [CrossRef] 
10. Bazza, M. Overview of the history of water resources and irrigation management in the near east region. In Proceedings of the 1st IWA International Symposium on Water and Wastewater Technologies in Ancient Civilizations, Iraklion, Greece, 28-30 October 2006; pp. 593-604.

11. Goblot, H. Dans L'ancien Iran: Les Techniques de L'eau et la Grande Histoire. Ann. Hist. Sci. Soc. 1963, 18, 499-520. [CrossRef]

12. Water Encyclopedia. Available online: http://www.waterencyclopedia.com/Hy-La/Irrigation-SystemsAncient.html (accessed on 30 December 2019).

13. Viollet, P.L. L'hydraulique Dans les Civilisations Anciennes—5000 ans D'histoire; Presses de l'Ecole Nationale des Ponts et Chaussées: Paris, France, 2005; p. 374.

14. Tamburrino, A. Water Technology in Ancient Mesopotamia. In Ancient Water Technologies; Mays, L.W., Ed.; Springer: New York, NY, USA, 2010; pp. 29-51.

15. Xiuling, Y. Several views about unearthed rice and bone plough in the fourth cultural layer of Hemudu archaeological site. Archaeol. J. 1976, 8, 23-26.

16. IA-CASS. Institute of Archaeology-Chinese Academy of Sciences. Zhongguo Kaoguxue Zhong Tanshisi Shujuji 1965-1991 (Radiocarbon Dating Data Set in Chinese Archaeology 1965-1991); Cultural Relies Publishing House: Beijing, China, 1991.

17. Zhenglang, Z. Research on Technologies of Ancient Cultivation According to Oracles of Shang dynasty. Archaeol. J. 1973, 1, 97-124.

18. Moody, J.; Grove, A.T. Terraces and Enclosure Walls in the Cretan Landscape. In Man's Role in the Shape of the Eastern Mediterranean Landscape; Bottema, S., Balkema, A.A., Eds.; CRC Press: Boca Raton, FL, USA, 1990; pp. 183-191.

19. Lyrintzis, A.; Angelakis, A.N. Is the Labyrinth a Water Catchment Technique? People and water management in Minoan Crete. In Proceedings of the 1st IWA International Symposium on Water and Wastewater Technologies in Ancient Civilizations, Iraklion, Greece, 28-30 October 2006; pp. 163-174.

20. Angelakis, A.N.; Spyridakis, S.V. The status of water resources in Minoan times: A preliminary study. In Diachronic Climatic Impacts on Water Resources with Emphasis on Mediterranean Region; Angelakis, A.N., Issar, A.S., Eds.; Springer: Heidelberg, Germany, 1996; pp. 161-191.

21. Angelakis, A.N.; Dialynas, M.G.; Despotakis, V. Evolution of Water Supply Technologies in Crete, Greece through the Centuries. In Evolution of Water Supply throughout Millennia; IWA Publishing: London, UK, 2012; pp. 227-258.

22. Yannopoulos, S.; Lyberatos, G.; Theodosiou, N.; Li, W.; Valipour, M.; Tamburrino, A.; Angelakis, A.N. Evolution of Water lifting devices (pumps) through the centuries worldwide. Water 2015, 7, 5031-5060. [CrossRef]

23. Water Management in Prehistoric Crete: The case of Choiromandres, Zakros. HYDRIA Project Collection, Storage \& Distribution of Water in Antiquity Linking Ancient Wisdom to Modern Needs. Available online: http://www.hydriaproject.info/en/greece-crete-water-management-in-zakros-area/importance3 (accessed on 5 December 2019).

24. Flood, J.M. Water Management in Neopalatial Crete and the Development of the Mediterranean Climate. Master's Thesis, The University of North Carolina, Chapel Hill, NC, USA, 2012.

25. Betancourt, P.P. The Dams and Water Management Systems of Minoan Pseira; INSTAP Academic Press: Philadelphia, PA, USA, 2012.

26. Celka, S.M.; Puglisi, D.; Bendali, F. Settlement pattern dynamics and natural resources in MM-lM I Crete: The case of Malia. In Physis: 'Environnement Naturel Et La Relation Homme-Milieu Dans Le MONDE Égéen Protohistorique; Touchais, G., Laffineur, R., Rougemont, F., Eds.; Peeters, Leuven: Liege, Belgium, 2014.

27. Betancourt, P.P.; Davaras, C.; Simpson, R.S. The Archaeological Survey of Pseira Island; INSTAP Academic Press: Philadelphia, PA, USA, 2004.

28. Angelakis, A.N.; Spyridakis, S.V. Wastewater Management in Minoan Times. In Proceedings of the Meeting on Protection and Restoration of Environment, Chania, Greece, 28-30 August 1996; pp. 549-558.

29. Wright, R.P.; Bryson, R.A.; Schuldenrein, J. Water supply and history: Harappa and the Beas regional survey. Antiquity 2008, 82, 37-48. [CrossRef]

30. Lawler, A. Boring no more, a trade-savvy Indus emerges. Science 2008, 320, 1276-1281. [CrossRef]

31. Violett, P.L. Water Engineering in Ancient Civilizations: 5000 Years of History; International Association of Hydraulic Engineering and Research (IAHR): Madrid, Spain, 2007. 
32. Kenoyer, M.J. Ancient Cities of the Indus Civilization; Oxford University Press: Oxford, UK, 1998; p. 260.

33. Kenoyer, J.M. Urban Process in the Indus Tradition: A Preliminary Model from Harappa. In Harappa Excavations 1986-1990; Meadow, R.H., Ed.; Prehistory Press: Madison, WI, USA, 1991; pp. $29-60$.

34. Irrigation Development in India: History \& Impact, Water Technology Centre, WTC, IARI, New Delhi. Available online: http://indiairrigation.blogspot.com/2009/01/history-of-irrigation-development-in_01.html (accessed on 30 December 2019).

35. Krasilnikoff, J.; Angelakis, A.N. Water management and its judicial contexts in ancient Greece: A review from the earliest times to the Roman period. Water Policy 2019, 21, 245-258. [CrossRef]

36. Harper, R.F. The Code of Hammurabi, King of Babylon, about 2250 BC (Translated); University of Chicago Press: Chicago, IL, USA, 1904.

37. Richardson, M.E.J. Hammurabi's Laws: Text, Translation, and Glossary; T\&T Clark: London, UK, 2004.

38. Shaw, B.D. Water and society in the Ancient Maghrib: Technology, property and development. Antiq. Afr. 1984, 20, 121-173. [CrossRef]

39. El Amami, S.; Chaabouni, Z. Traditional Hydraulic Reshaping: A Means of Controlling Water Erosion; Research Center of Rural Engineering: Tunis, Tunisia, 1981.

40. Criteria and Options for Appropriate Irrigation Methods. Available online: http://www.fao.org/3/W3094E/ w3094e05.htm (accessed on 27 December 2019).

41. Kees, H. Ancient Egypt: A Cultural Topography; University of Chicago Press: Chicago, IL, USA, 1961.

42. Noaman, M.N.; El Quosy, D. Hydrology of the Nile and ancient agriculture. In Irrigated Agriculture in Egypt: Past, Present and Future; Satoh, M., Aboulroos, S., Eds.; Springer: Cham, Switzerland, 2017; Volume 2, pp. 9-28.

43. Murray, G.W. A note on the Sadd el-Kafara: The ancient dam in wadi Garami. Bull. I'Institut d'Egvpte 1947, 28, 33-43.

44. Garbrecht, G. The Sadd el Kafara, the world's oldest dam. In Proceedings of the Special Session on History of Irrigation, 12th ICID Congress, Fort Collins, CO, USA, 28 May-2 June 1984.

45. Joffe, G. Irrigation and Water Supply Systems in North Africa; Moroccan Studies: Casablanca, Morocco, 1992.

46. Wikander, O. Sources of Energy and Exploitation of Power. In The Oxford Handbook of Engineering and Technology in the Classical World; Oleson, J.P., Ed.; Oxford University Press: Oxford, UK, 2008; pp. 136-157.

47. Cohn, G.S. L'origine des Norias de Fès; Hespéris: Fez, Morocco, 1933; pp. 156-157.

48. Angelfire. Available online: http://www.angelfire.com//journal/millbuilder/album5.html (accessed on 15 May 2018).

49. Worldwatch. Available online: hrrp://www.worldwatch.org (accessed on 30 December 2019).

50. Fedick, S. Land Evaluation and Ancient Maya Land Use in the Upper Belize. Lat. Am. Antiq. 1995, 6, 16-34. [CrossRef]

51. Witschey, W.R.T. Encyclopedia of the Ancient Maya; Rowman \& Littlefield Publishers: Lanham, MD, USA, 2015; p. 574.

52. Scarborough, V.; Dunning, N.P.; Tankersley, K.B.; Carr, C.; Weaver, E.; Gracioso, L.; Sadurní, N. Diccionari de l'any 1000 a Catalunya; Edicions 62: Barcelona, Spain, 1999; p. 24.

53. Doyle, J.A. Early Maya geometric planning conventions at El Palmar, Guatemala. J. Archaeol. Sci. 2013, 40, 793-798. [CrossRef]

54. Lucero, L.I.; Joel, D.; Gunn, J.D.; Scarborough, V.L. Climate change and classic Maya management. Water 2011, 3, 479-494. [CrossRef]

55. Scarborough, V.; Gallopin, G.G. A Water Storage Adaptation in the Maya Lowlands. Science 1991, 251, 658-662. [CrossRef]

56. Largest Ancient Maya Dam Found in Guatemala. Available online: http://www.sci-news.com/archaeology/ article00470.html (accessed on 30 December 2019).

57. Isendalh, C. The Weight of Water: A New Look at Pre-hispanic Puuc Maya. Anc. Mesoam. 2011, 22, $185-197$. [CrossRef]

58. Pohl, M.D.; Pope, K.O.; Jones, J.G.; Jacob, J.S.; Piperno, D.R.; de France, S.D.; Lentz, D.S.; Gifford, J.A.; Danforth, M.E.; Josserand, J.K. Early Agriculutre in the Maya Lowlands. Lat. Am. Antiq. 1996, 7, 355-372. [CrossRef]

59. Hodell, D.A.; Brenner, M.; Curtis, J.H.; Guilderson, T. Solar Forcing of Drought Frequency in the Maya Lowlands. Science 2001, 292, 1367-1370. [CrossRef] 
60. China Daily. Nanhu Lake. China Daily, 10 May 2010.

61. Chi, C.T. Key Economic Areas in Chinese History; George Allenand Unwin: London, UK, 1936.

62. Rackham, O. Ancient Landscapes. In The Greek City from Homer to Alexander; Murray, O., Price, S., Eds.; Oxford University Press: Oxford, UK, 1990; pp. 85-111.

63. Amanatidis, G.T.; Paliatsos, A.G.; Repapis, C.C.; Bartzis, J.G. Decreasing precipitation trend in the Marathon area, Greece. Int. J. Climatol. 1993, 13, 191-201. [CrossRef]

64. Krasilnikoff, J.A. Innovation in Ancient Greek Agriculture: Some Remarks on Climate and Irrigation. Class. Mediaev. 2014, 64, 95-116.

65. Garnse-y, P. Famine and Food Supply in the Graeco-Roman World. Responses to Risk and Crisis; Cambridge University Press: Cambridge, UK, 1988.

66. Glick, T.F. Irrigation and Society in Medieval Valencia; Cambridge Belknap Press of Harvard University Press: Cambridge, MA, USA, 1970.

67. Crouch, D.P. Water Management in Ancient Greek Cities; Oxford University Press: Oxford, UK, 1993.

68. Krasilnikoff, J.A. Water and farming in Classical Greece: Evidence, Method and Perspective. In Ancient History Matters: Studies Presented to Jens Erik Skydsgaard on His Seventieth Birthday; Ascani, V., Gabrielsen, K.K., Rasmussen, A.H., Eds.; L'Erma di Bretschneider: Rome, Italy, 2002; pp. 47-62.

69. Carroll-Spilleche, M. Der Antike Griechische Garten: Wohnen in der Griechischen Polis III; Deutscher Kunstverlag: Munich, Germany, 1989.

70. Osborne, R. Classical Greek Gardens: Between Farm and Paradise. In Garden History. Issues, Approaches, Methods. Dumbarton Oaks Colloquium on the History of Landscape Architecture XIII; Hunt, J.D., Ed.; Harvard University Press: Cambridge, MA, USA, 1992; pp. 373-391.

71. Foxhall, L. Olive Cultivation in Ancient Greece: Seeking the Ancient Economy; Oxford University Press: Oxford, UK, 2007.

72. Bowe, P. Civic and other public planting in ancient Greece. Stud. Hist. Gard. Des. Landsc. 2011, 31, $269-285$. [CrossRef]

73. Raaflaub, K.A. The Transformation of Athens in the Fifth Century. In Democracy, Empire, and the Arts in Fifth-Century Athens. Center for Hellenic Studies Colloquia 2; Boedeker, D., Raaflaub, K.A., Eds.; Harvard University Press: Cambridge, MA, USA, 1998; pp. 15-41.

74. Austin, M.M. The Hellenistic World from Alexander to the Roman Conquest. A Selection of Ancient Sources in Translation; Cambridge University Press: Cambridge, UK, 1981.

75. Knauss, J. Wasserbau und Siedlungsbedingungen im Altertum: Die Melioration des Kopaisbeckens durch die Minyer im 2. Jt. v. Chr. (Kopasis 2); Technische Universität München, Versuchsanstalt für Wasserbau und Wassermengenwirtschaft: Munich, Germany, 1987.

76. Knauss, J.; Heinrich, B.; Kalcyk, H. Die Wasserbauten der Minyer in der Kopais-die älteste Flussregulerung Europas. Bericht Nr. 50; Institut für Wasserbau und Wassermengenwirtschaft und Versuchsanstalt für Wasserbau, Oskar v. Miller-Institut, Obernach Technische Universität München: Munich, Germany, 1984.

77. Horden, P.; Purcell, N. The Corrupting Sea: A Study of Mediterranean History, 8th ed.; Wiley-Blackwell: Hoboken, NJ, USA, 2000; p. 776.

78. Lohmann, H. Atene: Forschungen zu Siedlungs-und Wirtschaftsstruktur des klassischen Attika; Bohlau Verlag: Koln, Germany, 1993.

79. Price, S.; Nixon, L. Ancient Greek Agricultural Terraces: Evidence from Texts and Archaeological Survey. Am. J. Archaeol. 2005, 109, 665-694. [CrossRef]

80. Moreno, A. Feeding the Democracy. The Athenian Grain Supply in the Fifth and Fourth Centuries BC; Oxford University Press: Oxford, UK, 2007.

81. Prieto, A. Landscape Organization in Magna Graecia. Ph.D. Thesis, University of Texas, Austin, TX, USA, 2005.

82. Wilson, A. Land drainage. In Handbook of Ancient Water Technology. Technology and Change in History, Vol. 2; Wikander, Ö., Ed.; Brill: Leiden, Belgium, 2000; pp. 303-317.

83. Margaritis, E.; Jones, M.K. Greek and Roman agriculture. In Handbook of Engineering and Technology in the Classical World; Oleson, G., Ed.; Oxford University Press: Oxford, UK, 2008; pp. 567-578.

84. Cato, M.P.; Varro, M.T. On Agriculture; Harvard University Press: Cambridge, MA, USA, 1934.

85. White, K.D. Roman Farming; Thames \& Hudson: London, UK, 1970.

86. Mays, L.W. A very brief History of Hydraulic Technology during Antiquity. Environ. Fluid Mech. 2008, 8 , 471-484. [CrossRef] 
87. Butzer, K.W.; Mateu, J.F.; Butzer, E.; Kraus, P. Irrigation agrosystems in eastern Spain: Roman or Islamic origins? Ann. Assoc. Am. Geogr. 1985, 75, 479-509. [CrossRef]

88. Lechtman, H.; Hobbs, L. Roman concrete and Roman architecture revolution. In High Technology Ceramics: Past, Present, and Future: The nature of Innovation and Change in Ceramic Technology; Kingery, W.D., Ed.; American Ceramic Society: Westerville, OH, UAS, 1986.

89. Pounds, N.J.G. An Historical Geography of Europe 450 BC-AD 1330; Cambridge University Press: Cambridge, UK, 1973.

90. Von Stackelberg, K.T. The Roman Garden: Space, Sense, and Society; Routledge: London, UK, 2009.

91. Fentress, E.; Quilici Gigli, S. La Domesticazione delle Piante e L'agricoltura: Mondo Greco e Mondo Romano. Available online: http://www.treccani.it/enciclopedia/la-domesticazione-delle-piante-e-l-agricoltura-mondo-grecoemondo-romano_\%28Il-Mondo-dell\$|delimiter"026E30F\$T1\$_delimiter"026E30F\$textquoterightArcheologia\%29/ (accessed on 20 October 2015).

92. Barker, G.; Gilbertson, D.; Jones, B.; Mattingly, D. Farming the Desert: The UNESCO Libyan Valleys Archaeological Survey; Graeme, B., Ed.; UNESCO/Department of Antiquities: Tripoli, Libya, 1996; Volume 1.

93. Kamash, Z. Irrigation technology, society and environment in the Roman Near East. J. Arid Environ. 2012, 86, 65-74. [CrossRef]

94. Smith, N.A. History of Dams; P. Davies: London, UK, 1971.

95. Belli, O. Urartian Irrigation Canals in Eastern Anatolia; Archeology and Art Press: Istanbul, Turkey, 1997.

96. Orhan, A.H. Urartian Water Constructions and Hydraulics; University of Yüzüncü Y1l: Tuşba, Van, Turkey, 2004.

97. Çifçi, A.; Greaves, A.M. Urartian Irrigation Systems. Anc. Near East. Stud. 2013, 50, 191-214.

98. Garbrecht, G. Historische Wasserbauten im Ost-Anatolien; DWhG: Siesburg, Germany, 2004.

99. English, P.W. The origin and spread of qanats in the Old World. Proc. Am. Philos. Soc. 1968, 112, $170-181$.

100. English, P.W. Qanats and Lifeworlds in Iranian Plateau Villages. In Proceedings of the Conference on Transformation of Middle Eastern Natural Environment: Legacies and Lessons, New Haven, CT, USA, 28 October-1 November 1997.

101. Miu, Q.Y. Research on History of Polders in the Taihu Lake Basin; Agricultural Press: Beijing, China, 1985.

102. Wang, Z. Annotation of Agricultural Treatise; Shandong Publishing Group: Jinan, China, 1313.

103. Plattner, G. Intergovernmental Panel on Climate Change. Climate Change 2014: Synthesis Report. Contribution of Working Groups I, II and III to the Fifth Assessment Report of the Intergovernmental Panel on Climate Change; IPCC: Geneva, Switzerland, 2014.

104. Morehar, C.T. Mapping ancient chinampa landscapes in the Basin of Mexico: A remote sensing and GIS approach. J. Archeol. Sci. 2012, 39, 2541-2551. [CrossRef]

105. Armillas, P. Gardens on swamps. Science 1971, 175, 653-661. [CrossRef]

106. Smith, M. The Aztec Silent Majority: William T. Sanders and the Study of the Aztec Peasantry. In Arqueología Mesoamericana; Alba Guadalupe Mastache, A., Parsons, J.R., Santley, R.S., Serra Puche, M.C., Eds.; Instituto Nacional de Antropología e Historia: Mexico City, Mexico, 1996; Volume 1, pp. 375-386.

107. McCaa, R. The Peopling of Mexico from Origins to Revolution. In The Population History of North America; Richard Steckel, R., Haines, M., Eds.; Cambridge University Press: Cambridge, UK, 2000; pp. 241-304.

108. DGCOH Dirección General de Construcción y Operación Hidráulica. El Sistema del Drenaje Profundo de la Ciudad de México, 3rd ed.; Dirección General de Construcción y Operación Hidráulica, Dirección Técnica, Subdirección de Programación: Distrito Federal Mexico, Mexico, 1996.

109. Palerm, A. Obras hidráulicas prehispánicas en el sistema lacustre del Valle de Mexico. Archaeol. Am. Anthropol. 1973, 78, 1245.

110. Rojas, R.A.; Strauss, K.; Lameiras, J. Technological aspects of the colonial hydraulic infrastructure. In New News on the pre Hispanic and Colonial Hydraulic Infrastructure in the Valley of Mexico; Minister of Public Education, National Institute of History and Anthropology: Distrito Federal Mexico, Mexico, 1974.

111. Luna, G.; Gregory, G. Late Aztec Chinampa Agriculture and Settlement on Lake Xochimilco: A GIS Analysis of Lakebed Chinampas and Settlement. Ph.D. Thesis, The Pennsylvania State University, State College, PA, USA, 2014.

112. Villalonga, A. Imperialismo Hidráulico de los Aztecas en la Cuenca de México. Rev. Tecnol. Agua 2007, 288, 78-91.

113. Chinampa: Raised-Bed Hydrological Agriculture. Available online: https:/anthrome.wordpress.com/2011/ 04/24/chinampa-raised-bed-hydrological-agriculture/ (accessed on 26 June 2013). 
114. Canabal-Cristiani, B.P.; Tortes-Lima; Burela-Rueda, G. La Ciudad y sus Shinampas; Universidad Autonoma Metropolitana-Xochimilco: Mexico City, Mexico, 1992.

115. Smith, M.E. The Aztecs; Wiley Blackwell: Hoboken, NJ, USA, 2013.

116. Coe, M.D. The chinampas of Mexico. Sci. Am. 1964, 211, 90-98. [CrossRef]

117. Netherly, P.J. The Management of Late Andean Irrigation Systems on the North Coast of Peru. Am. Antiq. 1984, 49, 227-254. [CrossRef]

118. Boelens, R.; Gelles, P.H. Cultural Politics, Communal Resistance and Identity in Andean Irrigation Development. Bull. Lat. Am. Res. 2005, 24,311-327. [CrossRef]

119. Barnebeck, A.T.; Sandholt, J.P.; Volmar, S.C. The heavy plow and the agricultural revolution in Medieval Europe. J. Dev. Econ. 2016, 118, 133-149.

120. Peix, J. L'aigua i el Medi: Gestió dels Regadius; Quaderns Agraris: Barcelona, Spain, 2002.

121. Squatriti, P. Water and Society in Early Medieval Italy, AD 400-1000; Cambridge University Press: Cambridge, UK, 2002.

122. Shanan, L. The impact of irrigation. In Land Transformation in Agriculture; Wolman, M.G., Fourier, F.G.A., Eds.; John Wiley \& Sons: New York, NY, USA, 1987; pp. 115-131.

123. Avdat-Negev Attractions. Available online: http://www.planetware.com/Negev/avdat-isr-st-av.htm (accessed on 20 December 2013).

124. Salgot, M.; Angelakis, A. The historical development of water supply technologies in Barcelona, Spain. In Evolution of Water Supply through the Millennia; IWA Publishing: London, UK, 2019.

125. Christensen, P. Middle Eastern Irrigation: Legacies and Lessons. Bull. Ser. Yale Sch. For. Environ. Stud. 1998, $103,15-29$.

126. Roldán, J.; Moreno, M.F. La ingeniería y la gestión del agua de riego en Al-Andalus. Ing. Agua 2007, 14, 223-236. [CrossRef]

127. Morell, A. «de la Vila». Fonts de Tramuntana. Available online: https://www.fontsdetramuntana.com/ (accessed on 18 November 2016).

128. Vivas, G.; Gómez-Landesa, E.; Mateos, L.; Giráldez, J.V. Integrated Water Management in an Ancestral Water Scheme in a Mountainous Area of Southern Spain; ASCE: Reston, VA, USA, 2009.

129. Mateos, L.; Vivas, G.; Giráldez, J.V.; González-dugo, M.P. Origin, tradition and decline of the ancestral irrigation systems in the high Alpujarra, Spain. In Proceedings of the Workshop History of Irrigation, Drainage and Flood Control, ICID 22nd European Regional Conference, Pavia, Italy, 2 September 2007.

130. De la Peña, J.L.; Ibarz, J.; Salgot, M. Water in the royal monastery of Santes Creus, Catalonia (Spain). In Proceedings of the 3rd Specialized Conference on Water and Wastewater Technologies in Ancient Civilizations, Istanbul, Turkey, 22-24 March 2012.

131. Das, S.K.; Gupta, R.K.; Varma, H.K. Flood and Drought Management through Water Resources Development in India. Bull. World Meter. Organ. 2007, 56, 3.

132. Postan, M.M. The Agrarian Life of the Middle Ages; Cambridge University Press: Cambridge, UK, 1966.

133. Şentürk, F. Hydraulics of Dams and Reservoirs; Water Resources Publications: Highlands Ranch, CO, USA, 1994.

134. Kuban, D. Tarih Vakfı yurt Yayın, Istanbul, A History of City: Istanbul; The Economic and Social History Foundation of Turkey: Istanbul, Turkey, 1996.

135. Inancık, H.; Arı, B. Urbanism in Turkish-Islamic-Ottoman Tradition and Studies of İnalcık. H. J. Turk. Res. Lit. 2005, 3, 25-56.

136. RTMCT. Ottoman Period Waterworks and Water Admınıstratıon System; Republic of Turkey Ministry of Culture and Tourism: Ankara, Turkey, 2005.

137. DSI. Water Resources in Turkey; General Directorate State Hydraulic Works: Ankara, Turkey, 2012.

138. Money, R.I. The irrigation of the Konia Plain. Geogr. J. 1919, 5, 298-303. [CrossRef]

139. Keenan, G. Fayyum Agriculture at the End of the Ayyubid Era: Nabulsi's Survey. In Agriculture in Egypt: From Pharaonic to Modern Times; Bowman, A.K., Rogan, E., Eds.; Oxford University Press for the British Academy: Oxford, UK, 1999; pp. 287-299.

140. Alan, M. An Irrigated Empire: The View from Ottoman Fayyum. Int. J. Middle East Stud. 2010, 42, 569-590.

141. Borsch, S.J. Environment and Population: The Collapse of Large Irrigation Systems Reconsidered. Comp. Stud. Soc. Hist. 2004, 46, 458-460. [CrossRef]

142. Quataert, D. The Ottoman Empire-1700-1922, 2nd ed.; Cambridge University Press: Cambridge, UK, 2005.

143. Mitchell, W. The Hydraulic Hypothesis. Curr. Anthropol. 1973, 14, 532-534. [CrossRef] 
144. Worster, D. Rivers of Empire: Water, Aridity $\mathcal{E}$ the Growth of the American West; Pantheon Books: New York, NY, USA, 1985.

145. Reisner, M. Cadillac Desert: The American West and Its Disappearing Water; Penguin Books: New York, NY, USA, 1986.

146. Freydank, K.; Siebert, S. Towards mapping the extent of irrigation in the last century: A time series of irrigated area per country. In Frankfurt Hydrology Paper 08; Institute of Physical Geography, University of Frankfurt: Frankfurt am Main, Germany, 2008.

147. Shiklomanov, I.A. Appraisal and assessment of world water resources. Water Int. 2000, 25, 11-32. [CrossRef]

148. Brown, L.B. Raising Water Productivity; Earth Policy Institute, Ratgers University: Washington, DC, USA, 2008.

149. Kadigi, R.M.J.; Tesfay, G.; Bizoza, A.; Zinabou, G. Irrigation and Water Use Efficiency in Sub-Saharan Africa; Global Development Network: Washington, DC, USA, 2012.

150. Xie, Y.; Zhou, X. Income inequality in todays' China. Proc. Natl. Acad. Sci. USA 2014, 111, $6928-6933$. [CrossRef]

151. Aquastat Database. Available online: http://faostat.org (accessed on 30 November 2019).

152. Faurès, J.M. The FAO Irrigated Area Forecast for 2030; Food and Agricultural Organization: Rome, Italy, 2002.

153. Postel, S. Last Oasis: The Worldwatch Environment Alert Series; W.W. Norton and Company: New York, NY, USA, 1992.

154. Shiklomanov, I.A. Comprehensive Assessment of the Freshwater Resources of the World: Assessment of Water Resources and Water Availability in the World; World Meteorological Organization and Stockholm Environment Institute: Stockholm, Sweden, 1997.

155. Siebert, S.; Doll, P. Irrigation water use. A global perspective. In Global Change: Enough Water for All? Lozán, J.L., Graßl, H., Hupfer, P., Menzel, L., Schönwiese, C.D., Eds.; Universität Hamburg: Hamburg, Germany, 2007; pp. 104-107.

156. Sojka, R.E.; Bjorneberg, D.L.; Entry, J.A. Irrigation: An historical perspective. In Encyclopedia of Soil Science, 1st ed.; Lal, R., Ed.; Marcel Dekker, Inc.: New York, NY, USA, 2002; pp. 745-749.

157. Leibundgut, C.; Kohn, I. European Traditional Irrigation in Transition Part I: Irrigation in Times Past-A historic land use practice across Europe. Irrig. Drain. 2014, 63, 273-293. [CrossRef]

158. Domokos, M.; Kálmán, M. Summary and conclusions, in Danube Valley. In History of Irrigation, Drainage and Flood Control; Csekő, G., Hayde, L., Eds.; ICID: New Delhi, India, 2004; pp. 679-715.

159. Bucks, D.A.; Sammis, T.W.; Dickey, G.L. Irrigation for Arid Areas. In Management of Farm Irrigation Systems; Hoffman, G.J., Howell, T.A., Solomon, K.H., Eds.; ASAE: Washington, DC, USA, 1990; pp. 499-548.

160. National Research Council (USA). A New Era for Irrigation; National Academy Press: Washington, DC, USA, 1996.

161. National Research Council (USA). Water Transfers in the West: Efficiency, Equity, and the Environment; National Academy Press: Washington, DC, USA, 1992.

162. UNESCO. The 2nd UN World Water Development Report: "Water, a Shared Responsibility"; UNESCO: Paris, France, 2006.

163. Gleick, P. An Introduction to Global Fresh Water Issues. In Water in Crisis-A Guide to World's Fresh Water Resources; Gleick, P., Ed.; Oxford University Press: New York, NY, USA, 1993.

164. Kendall, H.; Pimentel, D. Constraints on the expansion of the global food supply. Ambio 1994, 23, $198-205$.

165. Howell, T.A. Irrigation's Role in Enhancing Water Use Efficiency. In Proceedings of the 4th Decennial Symposium; Evans, R.G., Benham, B.L., Trooien, T.P., Eds.; ASAE: Washington, DC, USA, 2000; pp. 66-80.

166. Rhoades, J.D. Sustainability of Irrigation: An Overview of Salinity Problems and Control Strategies. In Proceedings of the 1997 Annual Conference of Canadian Water Resources Association, Footprints of Humanity: Reflections on Fifty Years of Water Resources Development, Lithbridge, AB, Canada, 3-6 June 1997; pp. 1-40.

167. Ghassemi, F.; Jakeman, A.J.; Nix, H.A. Salinisation of Land and Water Resources; University of New South Wales Press Ltd.: Canberra, Australia, 1995.

168. Cerrillo, A. Los ocho naufragios del canal Segarra-Garrigues (The eigth failures of the Segarra-Garrigues canal). La Vanguardia Newspaper, 18 November 2005.

169. WWAP. The United Nations World Water Development Report 4: Managing Water under Uncertainty and Risk, Vol. 1; UNESCO: Paris, France, 2012. 
170. Jensen, M.E.; Burman, R.D.; Allen, R.G. Evapotranspiration and Irrigation Water Requirements; ASCE Manuals and Reports on Engineering Practice, 70; ASCE: New York, NY, USA, 1990.

171. Sojka, R.E. Understanding and Managing Irrigation-Induced Erosion. In Advances in Soil and Water Conservation; Pierce, F.J., Frye, W.W., Eds.; Sleeping Bear Press: Ann Arbor, MI, USA, 1998; pp. 21-37.

172. Walker, W.R.; Zaccaria, D. Agricultural Water Management Challenges in the Western US. Discussion Paper. Presented at the NSF Water Workshop, Cairo, Egypt, 10-14 August 2014.

173. Levidow, L.; Zaccaria, D.; Maia, R.; Vivas, E.; Todorovic, M.; Scardigno, A. Improving water-efficiency irrigation: Prospects and difficulties of innovative practices. Agric. Water Manag. 2014, 146, 84-94. [CrossRef]

174. Angelakis, A.N.; Voudouris, K.S.; Tchobanoglous, G. Evolution of Water Supplies in the Hellenic World Focusing on the Water Treatment and Modern Parallels Water Supply. Available online: https://iwaponline. com/ws/article/doi/10.2166/ws.2020.032/72561/Evolution-of-water-supplies-in-the-Hellenic-world (accessed on 30 December 2019).

175. UN. Population 2030: Demographic Challenges and Opportunities for Sustainable Development Planning; UN: New York, NY, USA, 2015.

176. Paranychianakis, N.V.; Salgot, M.S.; Snyder, A.; Angelakis, A.N. Quality Criteria for Recycled Wastewater Effluent in EU-Countries: Need for a Uniform Approach. Crit. Rev. Environ. Sci. Technol. 2015, 45, 1409-1468. [CrossRef]

177. Tzanakakis, V.E.; Koo-Oshima, S.; Haddad, M.; Apostolidis, N.; Angelakis, A.N. The History of Land Application and Hydroponic Systems for Wastewater Treatment and Reuse. In Evolution of Sanitation and Wastewater Management through the Centuries; Angelakis, A., Rose, J., Eds.; IWA Publishing: London, UK, 2014; pp. 459-482.

178. Salgot, M.; Oron, G.; Cirelli, G.; Dalezios, N.R.; Díaz, A.; Angelakis, A.N. Criteria for Wastewater Treatment and Reuse under Water Scarcity. In Handbook of Drought and Water Scarcity: Environmental Impacts and Analysis of Drought and Water; Eslamian, S., Eslamian, F., Eds.; CRC Press: Boca Raton, FL, USA, 2016.

179. Hill, D.R. A History of Engineering in Classical and Medieval Times; Croom Helm: London, UK, 1984.

180. Dillehay, T.D.; Eling, H.H., Jr.; Rossen, J. Preceramic Irrigation Canals in the Peruvian Andes. Proc. Natl. Acad. Sci. USA 2005, 102, 17241-17244. [CrossRef] [PubMed]

181. Rodda, J.C.; Ubertini, L. The Basis of Civilization-Water Science; ISHS Proceedings \& Reports: Wallingford, UK, 2004; Volume 286, p. 342.

(C) 2020 by the authors. Licensee MDPI, Basel, Switzerland. This article is an open access article distributed under the terms and conditions of the Creative Commons Attribution (CC BY) license (http://creativecommons.org/licenses/by/4.0/). 